\title{
Shoreline Retreat of the Corte Madera Marshes, 1853 to 2016, Marin County, California
}

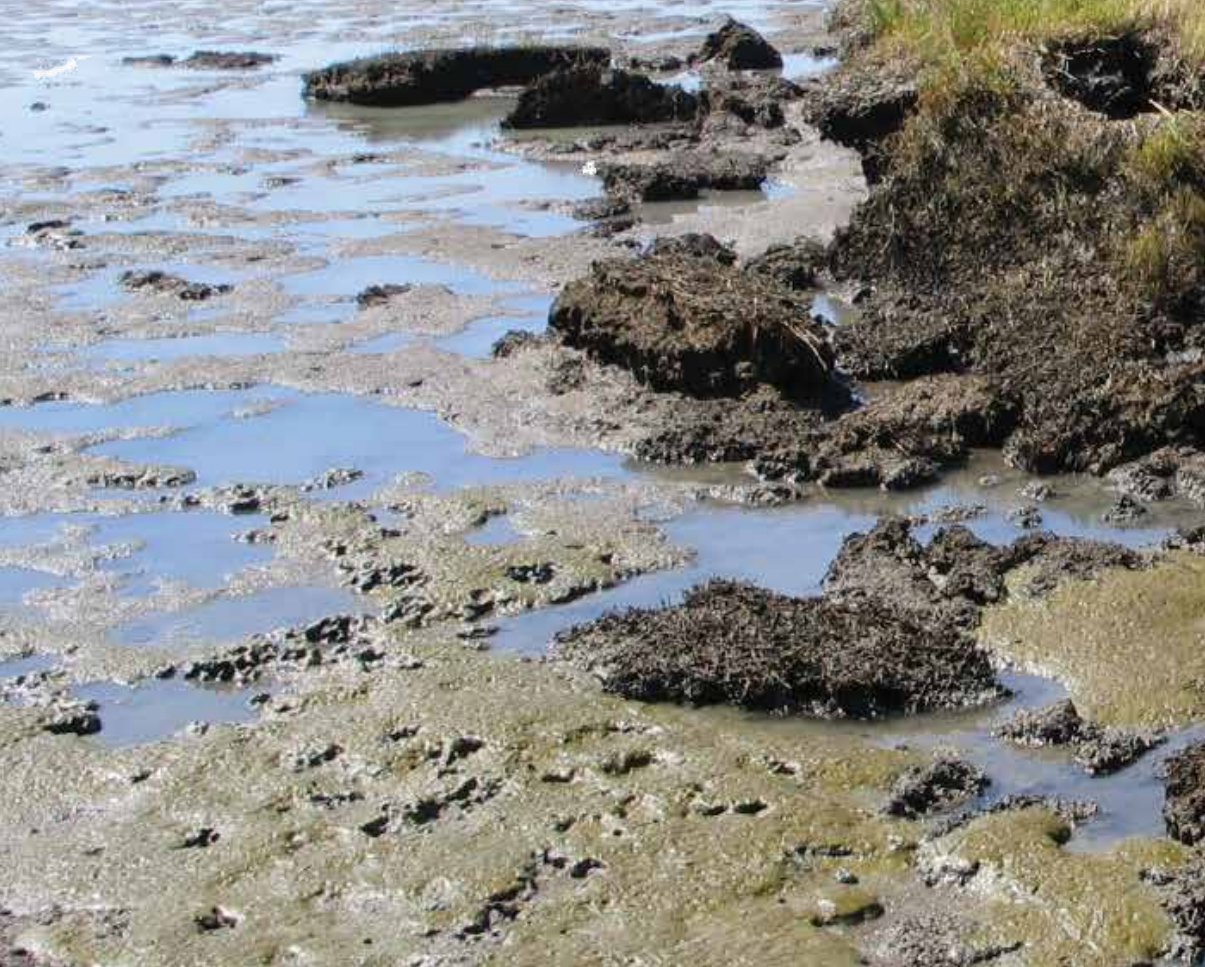

\section{$y^{2}+s^{2}$}

US Department of the interior

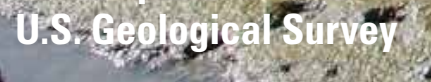

2.7.

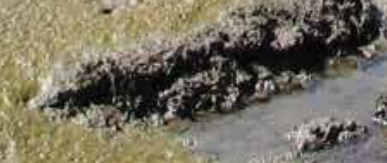

3.

2) 
Cover. View to south in 2010 at the shoreline of Heerdt marsh, Corte Madera, Marin County, California. 


\section{Shoreline Retreat of the Corte Madera Marshes, 1853 to 2016, Marin County, California}

By Bradley A. Carkin, Robert E. Kayen, and Florence L. Wong

Open-File Report 2020-1074 


\section{U.S. Department of the Interior DAVID BERNHARDT, Secretary}

\section{U.S. Geological Survey James F. Reilly II, Director}

U.S. Geological Survey, Reston, Virginia: 2020

For more information on the USGS - the Federal source for science about the Earth, its natural and living resources, natural hazards, and the environment-visit https://www.usgs.gov or call 1-888-ASK-USGS.

For an overview of USGS information products, including maps, imagery, and publications, visit https://store.usgs.gov.

Any use of trade, firm, or product names is for descriptive purposes only and does not imply endorsement by the U.S. Government.

Although this information product, for the most part, is in the public domain, it also may contain copyrighted materials as noted in the text. Permission to reproduce copyrighted items must be secured from the copyright owner.

Suggested citation:

Carkin, B.A., Kayen, R.E., and Wong, F.L., 2020, Shoreline retreat of the Corte Madera marshes, 1853 to 2016 , Marin County, California: U.S. Geological Survey Open-File Report 2020-1074, 36 p., 6 appendixes, https://doi.org/10.3133/ofr20201074.

ISSN 2331-1258 (online) 


\section{Contents}

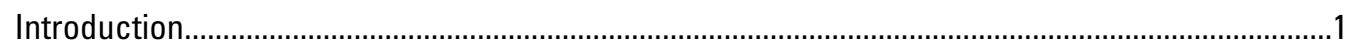

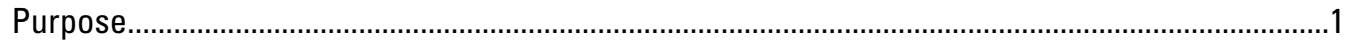

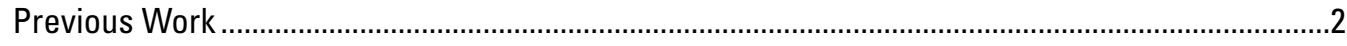

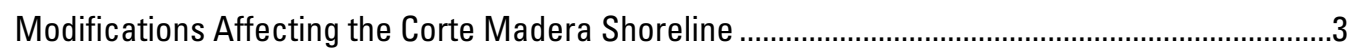

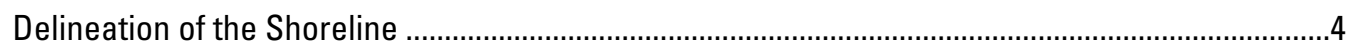

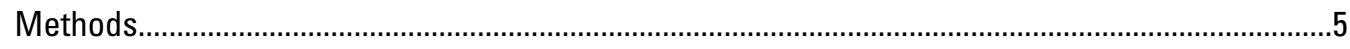

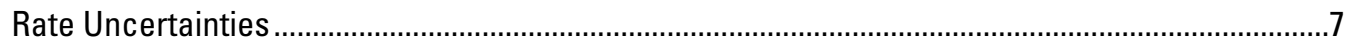

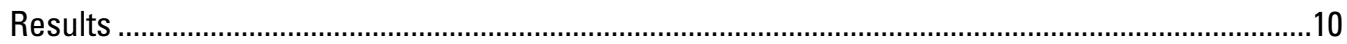

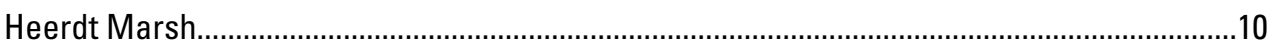

North Muzzi Marsh—North and South Sections ……........................................................12

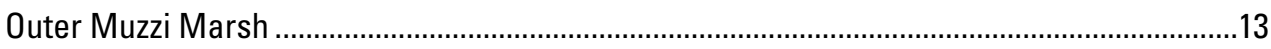

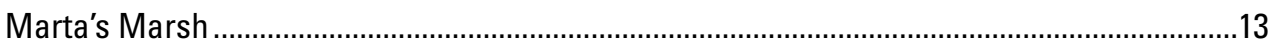

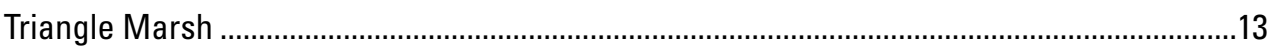

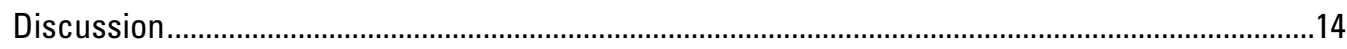

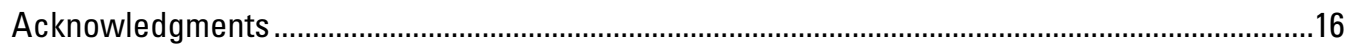

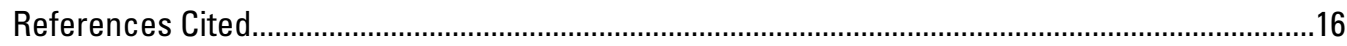

Appendix 1. End Point Rates for Corte Madera Creek (CC) and Heerdt Marsh (HM-1 through HM-7) Rate-Calculation Zones, Corte Madera Shoreline .....................................................17

Appendix 2. End Point Rates for North Muzzi Marsh (North) Rate-Calculation Zone NM-N,

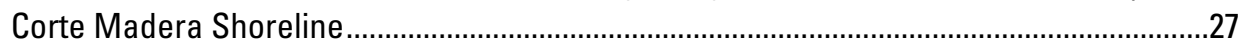

Appendix 3. End Point Rates for North Muzzi Marsh (South) Rate-Calculation Zone NM-S, Corte Madera Shoreline .............................................................................................29

Appendix 4. End Point Rates for Outer Muzzi Marsh Rate-Calculation Zone OM, Corte

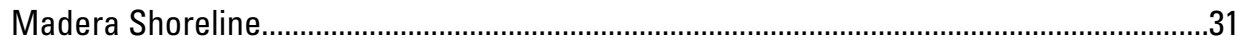

Appendix 5. End Point Rates for Marta's Marsh Rate-Calculation Zone MM, Corte Madera

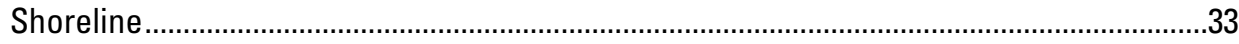

Appendix 6. End Point Rates for Triangle Marsh Rate-Calculation Zone TM, Corte Madera Shoreline ................................................................................................................... 


\section{Figures}

1. Map showing location of Corte Madera shoreline study area ...........................................1

2. Map showing locations of named Corte Madera marsh tracts in study area, as well as rate-calculation zones and georeferencing tie points established along Corte Madera shoreline

3. Aerial photograph (ca. 1931) of dike and shallow borrow canal, in area that is now part of Heerdt and north Muzzi marshes, Corte Madera shoreline.

4. View to southwest, toward mouth of "East Side Outfall Channel," of characteristic shoreline at Heerdt marsh, Corte Madera shoreline, in July 2010, showing steep scarp, vegetated surface and degrading, detached soil blocks

5. Large, collapsed block of marsh soil at Heerdt marsh, Corte Madera shoreline ...............5

6. Aerial photograph (ca. 1965) of Muzzi dike and borrow canal at what is now Marta's marsh, Corte Madera shoreline

7. Diagrams showing nonorthogonal versus orthogonal shoreline-transect relations for three irregular shorelines (S1, S2, S3) at Corte Madera shoreline .............................

8. Example of georeferencing of imagery used for study at Corte Madera shoreline ...........8

9. Satellite image showing closer view of residential deck depicted in figure $8 A$ on Corte Madera shoreline

10. Diagram illustrating positional variations of shoreline at Corte Madera shoreline ..........9

11. Map of shoreline change at northern part of Heerdt marsh, Corte Madera shoreline ..11

12. Map of shoreline change at mouth of Shorebird channel at Heerdt marsh, Corte Madera shoreline.....

13. Plot showing end point rate (EPR) values (blue line) for Heerdt marsh rate-calculation zones HM-1 to HM-7, Corte Madera shoreline, for study years 1931 to 2016.

14. Aerial photographs of part of north Muzzi marsh (south) near mouth of former "Salt Marsh creek," Corte Madera shoreline, showing shoreline changes....................14

15. Map of shoreline change at Marta's marsh, Corte Madera shoreline .............................14

16. Plots of cumulative net shoreline movement during modern period of 1931 to 2016 for seven shoreline rate-calculation zones, Corte Madera shoreline. 15

17. Variations in average end point rate values (red dots) along Corte Madera shoreline, 1931 to 2016

1-1. Map showing rate-calculation zones at Corte Madera Creek (CC) and Heerdt marsh (HM-1 through HM-7), Corte Madera shoreline

1-2. Plot showing end point rate values for Corte Madera Creek rate-calculation zone CC, Corte Madera shoreline

1-3. Plot showing end point rate values for Heerdt marsh rate-calculation zone HM-1, Corte Madera shoreline...

1-4. Plot showing end point rate values for Heerdt marsh rate-calculation zone HM-2, Corte Madera shoreline..

1-5. Plot showing end point rate values for Heerdt marsh rate-calculation zone HM-3, Corte Madera shoreline.

1-6. Plot showing end point rate values for Heerdt marsh rate-calculation zone HM-4, Corte Madera shoreline

1-7. Plot showing end point rate values for Heerdt marsh rate-calculation zone HM-5, Corte Madera shoreline...

1-8. Plot showing end point rate values for Heerdt marsh rate-calculation zone HM-6, Corte Madera shoreline.. 
1-9. Plot showing end point rate values for Heerdt marsh rate-calculation zone HM-7,

Corte Madera shoreline.

2-1. Map showing north Muzzi marsh (north) rate-calculation zone NM-N, Corte

Madera shoreline

2-2. Plot showing end point rate values for north Muzzi marsh (north) rate-calculation zone NM-N, Corte Madera shoreline

3-1. Map showing north Muzzi marsh (south) rate-calculation zone NM-S, Corte Madera shoreline.

3-2. Plot showing end point rate values for north Muzzi marsh (south) rate-calculation zone NM-S, Corte Madera shoreline

4-1. Map showing outer Muzzi marsh rate-calculation zone 0M, Corte Madera shoreline.31

4-2. Plot showing end point rate values for outer Muzzi marsh rate-calculation zone OM, Corte Madera shoreline.

5-1. Map showing Marta's marsh rate-calculation zone MM, Corte Madera shoreline .......33

5-2. Plot showing end point rate values for Marta's marsh rate-calculation zone MM,

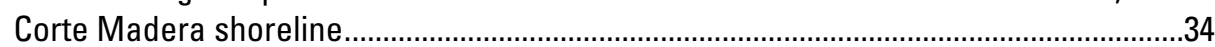

6-1. Map showing Triangle marsh rate-calculation zone TM, Corte Madera shoreline ........35

6-2. Plot showing end point rate values for Triangle marsh rate-calculation zone TM, Corte Madera shoreline.

\section{Tables}

1. Types of, and sources for, imagery used in shoreline studies, Corte Madera shoreline

2. Positional variation measured at corners of seawall at Mariner Cove subdivision, Corte Madera

3. Estimated end point rate uncertainties for epochs from 1965 to 2016, Corte Madera shoreline.

4. Historical and modern end point rates for rate-calculation zones, Corte Madera shoreline

1-1. Measured net shoreline movement and end point rate values determined for Corte Madera Creek rate-calculation zone CC, Corte Madera shoreline

1-2. Measured net shoreline movement and end point rate values determined for Heerdt marsh rate-calculation zone HM-1, Corte Madera shoreline.

1-3. Measured net shoreline movement and end point rate values determined for Heerdt marsh rate-calculation zone HM-2, Corte Madera shoreline.

1-4. Measured net shoreline movement and end point rate values determined for Heerdt marsh rate-calculation zone HM-3, Corte Madera shoreline.

1-5. Measured net shoreline movement and end point rate values determined for Heerdt marsh rate-calculation zone HM-4, Corte Madera shoreline.

1-6. Measured net shoreline movement and end point rate values determined for Heerdt marsh rate-calculation zone HM-5, Corte Madera shoreline

1-7. Measured net shoreline movement and end point rate values determined for Heerdt marsh rate-calculation zone HM-6, Corte Madera shoreline

1-8. Measured net shoreline movement and end point rate values determined for Heerdt marsh rate-calculation zone HM-7, Corte Madera shoreline. 
2-1. Measured net shoreline movement and end point rate values determined for north Muzzi marsh (north) rate-calculation zone NM-N, Corte Madera shoreline

3-1. Measured net shoreline movement and end point rate values determined for north Muzzi marsh (south) rate-calculation zone NM-S, Corte Madera shoreline .30

4-1. Measured net shoreline movement and end point rate values determined for outer Muzzi marsh rate-calculation zone OM, Corte Madera shoreline

5-1. Measured net shoreline movement and end point rate values determined for Marta's marsh rate-calculation zone MM, Corte Madera shoreline

6-1. Measured net shoreline movement and end point rate values determined for Triangle marsh rate-calculation zone TM, Corte Madera shoreline... 


\title{
Shoreline Retreat of the Corte Madera Marshes, 1853 to 2016, Marin County, California
}

\author{
By Bradley A. Carkin, Robert E. Kayen, and Florence L. Wong
}

\section{Introduction}

The greater San Francisco Bay estuary, prior to human intervention, encompassed about 2,200 $\mathrm{km}^{2}$ of tidal and salt marshes (Atwater and others, 1979). Over time, these areas became increasingly diked, developed, and altered from their natural state. In addition, natural forces are always driving a continually shifting equilibrium.

This study area, the Corte Madera marshes, is a tidal marsh or wetland located in southeastern Marin County, and it borders an embayment of central San Francisco Bay along about $2.8 \mathrm{~km}$ of shoreline (fig. 1). Most of this shoreline is located within the Corte Madera Marsh Ecological Reserve, managed by the California Department of Fish and Wildlife. Other areas within the marsh include (1) unincorporated Greenbrae (at the boardwalk), (2) diked land (that is, isolated from tidal action) owned by the Golden Gate Bridge Highway and Transportation District, and (3) urbanized areas such as in the Mariner Cove subdivision of Corte Madera (fig. 2).

The present tidal marsh area was historically subdivided into the following informally named tracts (fig. 2), listed from north to south: Heerdt marsh, north Muzzi marsh, inner and outer Muzzi marshes, Marta’s marsh, and Triangle marsh.

\section{Purpose}

The purpose of this study is to derive the magnitudes and rates of shoreline change (both erosion and accretion) for the Corte Madera shoreline, with particular emphasis on the time period from 1931 to 2016. The rates of change are then related to different shoreline types (that is, natural or diked) and (or) locations on the shoreline.

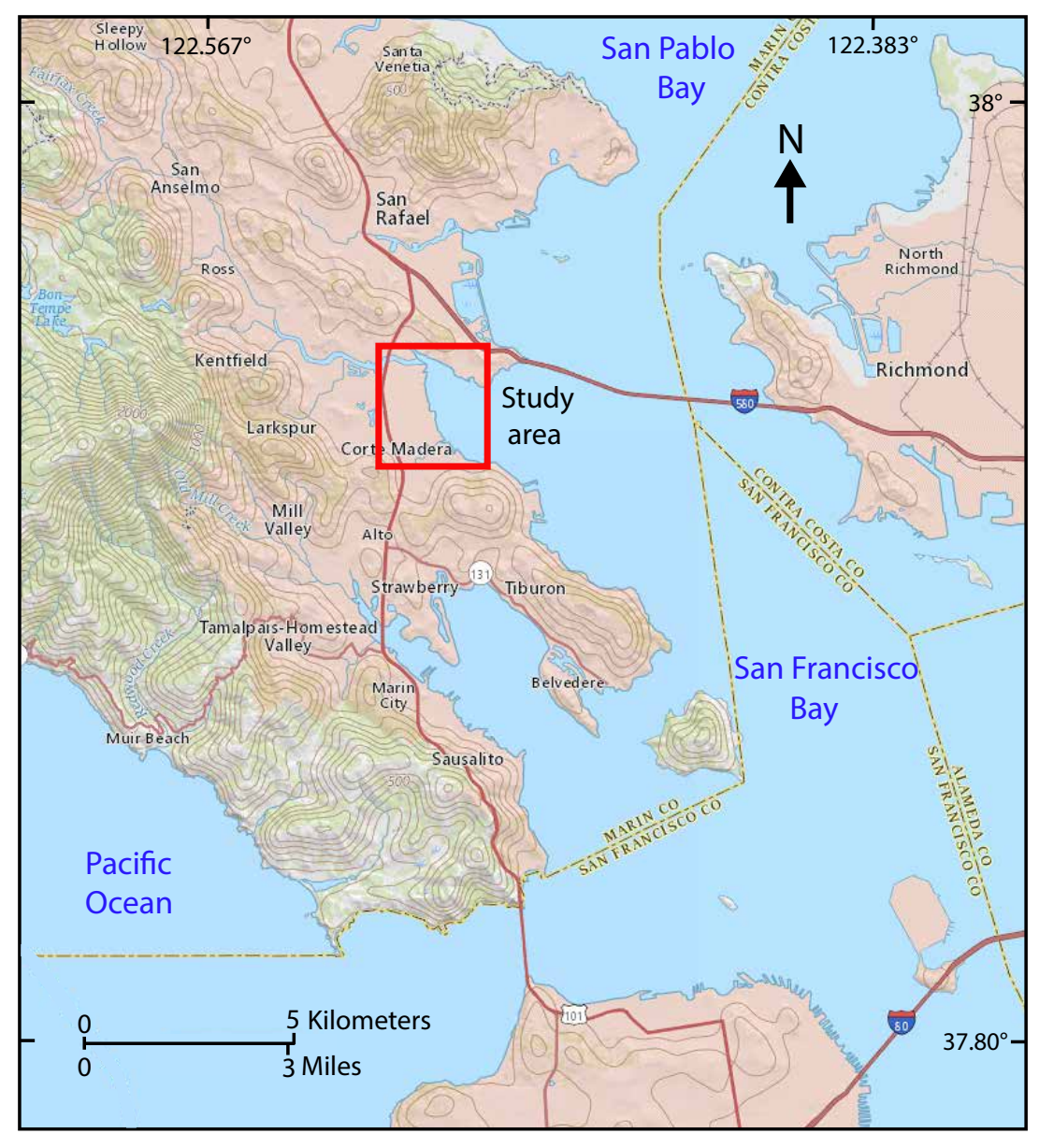

Figure 1. Map showing location of Corte Madera shoreline study area (red box) as part of San Francisco Bay shoreline, Marin County, California. Base map from Esri. 


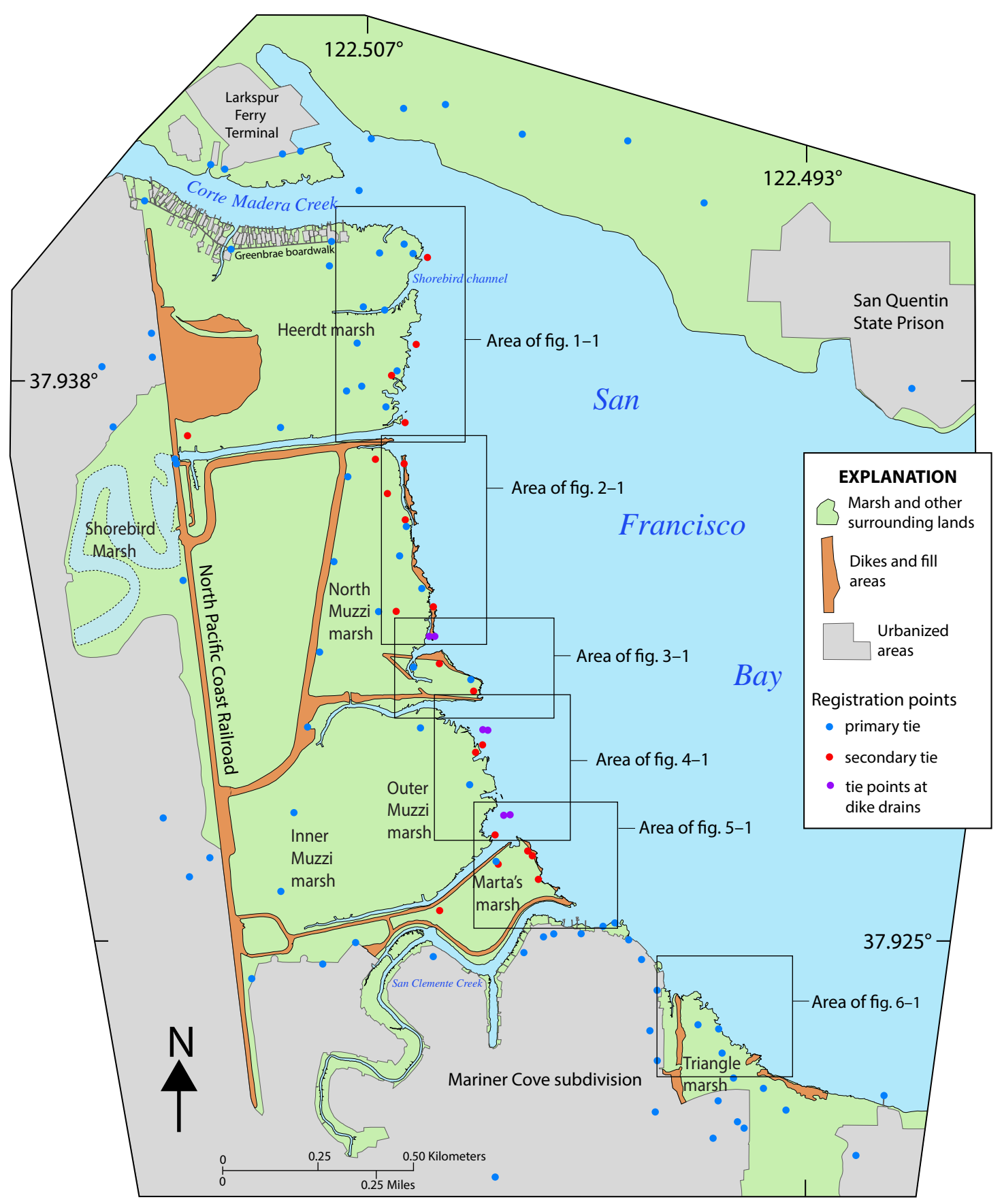

Figure 2. Map showing locations of named Corte Madera marsh tracts in study area, as well as rate-calculation zones (black boxes) and georeferencing tie points established along Corte Madera shoreline.

\section{Previous Work}

As marsh-restoration efforts began in the greater San Francisco Bay area, the Corte Madera marshland became one of the earliest sites to document marsh recovery. Much of the previous work involved measurement of vegetation composition and tidal-channel morphology (Faber, 1980; Faber and others, 1988). Lacy and Hoover (2011) gathered statistics of waves and currents at the Corte Madera marsh during a two-month period in the winter of 2010. Brah (1982) documented the political processes and the decisions that were made that affected the site, including those that led to the area being designated for restoration.

Estimated rates of change along the Corte Madera shoreline between 1853 and 2006 were compiled by James Zoulas (U.S. Army Corps of Engineers, unpub. data, 2013; document BCDC-ESA PWA), who determined an average total retreat of $148 \mathrm{~m}$ of shoreline, which amounts to nearly $1 \mathrm{~m} / \mathrm{yr}$ as a 
long-term average rate. Retreat rates averaged about $1.1 \mathrm{~m} / \mathrm{yr}$ from 1853 to 1930; they decreased to $0.3 \mathrm{~m} / \mathrm{yr}$ from 1930 to 1978, then increased to about $1.1 \mathrm{~m} / \mathrm{yr}$ from 1978 to 2006.

Callaway and others (2012) measured long-term vertical accretion rates at Corte Madera marsh (specifically, at Heerdt marsh) during 2011 and 2012 as 0.36 to $0.44 \mathrm{~cm} / \mathrm{yr}$. These rates are similar to those measured at other marshes around San Francisco Bay; such rates appear to be effective at maintaining marsh elevations relative to ongoing sea-level rise.

\section{Modifications Affecting the Corte Madera Shoreline}

The Corte Madera marshland has been heavily impacted by human actions since the 1850s, although not all of these changes have directly involved the shoreline. The first significant incursion into the marshland was the construction of the elevated roadbed of the North Pacific Coast Railroad in 1875. Now functioning as a flood-control dike, the railroad truncated several large tidal channels. One historically large channel south of Corte Madera Creek, referred to here as the Shorebird channel (fig. 3; see also, fig. 1-1, in appendix 1), has largely filled in with sediment over time, and the shoreline at its mouth has adjusted significantly to a new configuration. Farther inland, Shorebird Marsh preserves some remnants of this channel's large meanders. The south shoreline of Corte Madera Creek, along the Greenbrae boardwalk, was armored with riprap between 1986 and 1992.

Aerial photographs from 1930 and 1931 reveal a low side-cast dike and an adjacent bay-side borrow canal (fig. 3). This dike and a later (1959) one were constructed by a digger, either on a barge or on the dike, whereby the creation of the canal is a consequence of extracting material for the dike. This dike, possibly constructed in 1924, is about $600 \mathrm{~m}$ long and is located at the east shoreline of what is now called Heerdt marsh. The dike terminates some smaller tidal channels and allows larger ones to pass through: the north end of the dike appears to be terminated by erosion at the mouth of the Shorebird channel; its south end appears to be terminated as if uncompleted. Traces of the dike remained visible in imagery until at least 1974.

Marshland east of the railroad bed, once owned by Domenic Muzzi, was considered to be useful as industrial land. In 1959, about $0.93 \mathrm{~km}^{2}$ of that land was enclosed by a substantial, 2.8-km-long side-cast dike, evidently as a first stage of a proposed development, but nothing ever came from the plans. Excavation of material for the dike resulted in a parallel channel (borrow canal) along the bay side, on the north side of the dike. The north-side channel would become known as the "East Side Outfall Channel," which drains land west of the railroad bed and east of Interstate 101 . In the central shoreline area, the former "Salt Marsh creek" (see fig. 3-1 [in appendix 3] for approximate location) and its mouth have been entirely obliterated by diking, erosion, and sedimentary infilling.
Development of the Mariner Cove residential subdivision in Corte Madera began as early as 1950, and development on the marsh flat was completed by the mid-1960s. The subdivision is largely inland of the shoreline, but the position of about $400 \mathrm{~m}$ of shoreline southeast of the mouth of San Clemente Creek has been fixed by stages of armoring with seawalls and riprap. An isolated remnant of the tidal marsh, about 4.5 hectares (ha) adjacent to the eastern margin of the subdivision, is known as Triangle marsh.

As part of an effort to restore tidal action to the marsh, the east side of the Muzzi dike was breached in four places on June 3, 1976. Prior to this, between 1965 and 1970, culverts were installed in the dike in three places near the eventual dike breaches, probably as drainage points for the water from dredge spoils pumped onto the marsh. In 1981, channels surrounding inner and outer Muzzi marshes were extended and enlarged (Faber and others, 1988), but they rapidly filled with sediment; since then, the shoreline has been allowed to erode naturally. Between 2000 and 2002, an opening was created in the interior dike that allowed greater tidal exchange to Marta's marsh.

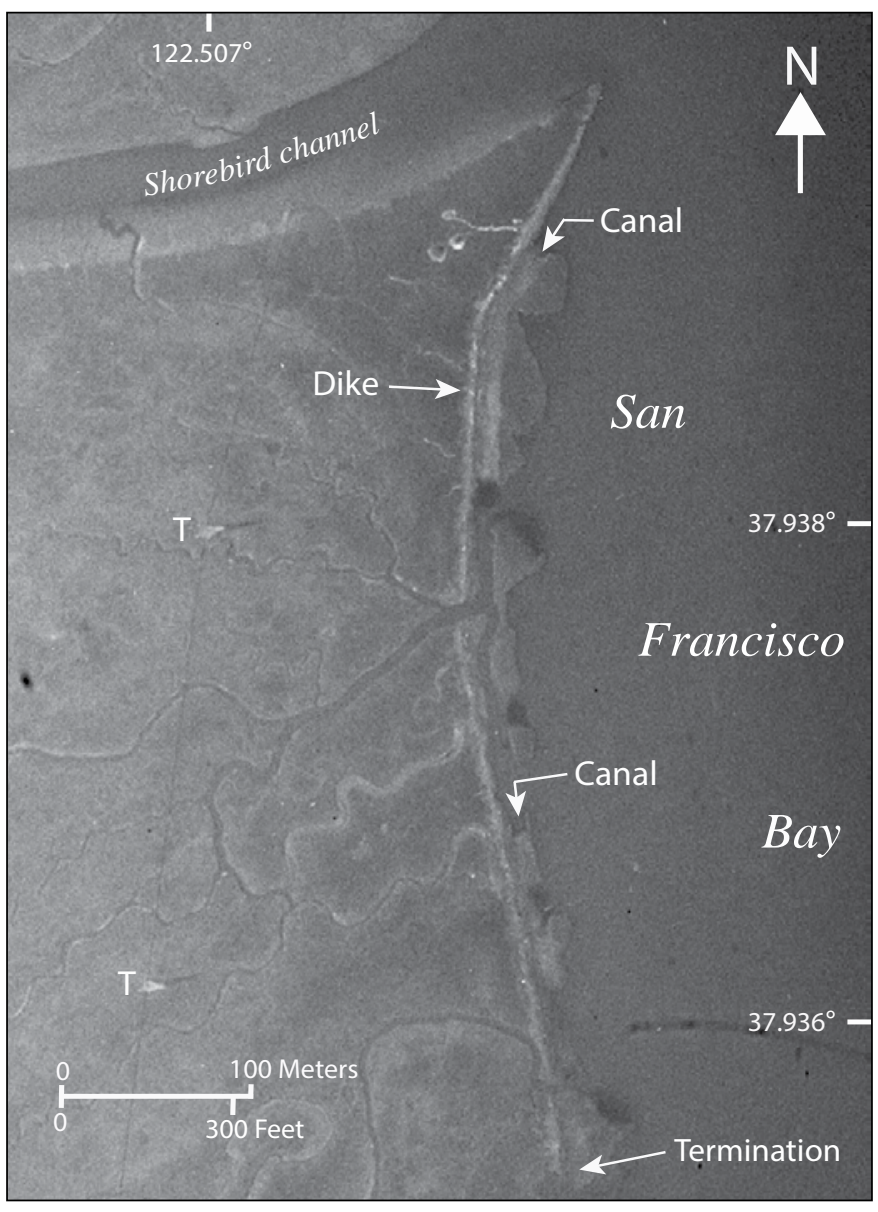

Figure 3. Aerial photograph (ca. 1931) of dike and shallow borrow canal, in area that is now part of Heerdt and north Muzzi marshes, Corte Madera shoreline. Abbreviation: T, transmission towers. Image from Fairchild Aerial Surveys. 


\section{Delineation of the Shoreline}

Some studies identify a shoreline by signs of water levels or by projecting modeled tide datums onto land (for example, high water line, mean high water). In contrast, for this study the shoreline at Corte Madera is defined as the edge of the marsh, a distinctive landform composed of stiff, cohesive, silt- and clay-rich sediment, as well as a vegetated surface and a root layer. For tracing purposes, we identified it variously by one or more of the following three features:

1. A sharp break or scarp, which typically has a height of a meter or less above the mud flat (fig. 4) and whose visibility often is enhanced in images by its shadow; the sharp, vertical scarp may be undercut to some degree or may be a rolled-over layer of vegetation and roots. Images at low-tide levels are preferable as they allow the scarp shadow to be visible. In addition, the position of the scarp at Corte Madera marsh does not vary cyclically (either seasonally or tidally), and it has a uniform elevation.

2. Either the margin of an established vegetated surface or the shoreward margin of the vertical break, where it may be broader or steplike; the margin is lesser in extent and is usually located in areas not directly facing the bay or along old dredged channels; it may be a "trimline" in the vegetation on the marsh where erosion has broken through the dike.

3. The paths of cracks or gaps, where undercut and detaching soil blocks have not yet fully toppled onto the mud flat (fig. 5).
Using combinations of these characteristics, the location of the marsh edge over much of its length and throughout much of the study period can be fairly well identified, independent of the tide level, especially for the later images (2000 to 2016).

Some uncertainty arose in interpreting the shoreline in the central part of the study area, mainly as a consequence of the former excavated channel (borrow canal), which was dug as source material for the side-cast Muzzi dike. The channel, excavated in 1959 just inboard of the shoreline, typically is 10 to $13 \mathrm{~m}$ wide, and it created residual "barrier islands" along a distance of about $1.4 \mathrm{~km}$ (fig. 6). These islands progressively eroded away on their bay side over the next 30 years. While the islands eroded, sediments variably accumulated, supporting some vegetation within parts of the protected areas in the canal. This accumulated material then underwent erosion at the same time as the island remnants and the shoreline adjacent to the dike. Because this process predated this study, and because the islands and infilled areas have entirely disappeared, the varying conditions of this erosion have not been observed, nor have the composition and degree of consolidation of any infill been recorded. Similarly, the dike and borrow canal at Heerdt marsh (visible in the 1931 imagery) also must have created barrier islands and other features similar to those caused by the 1959 dike. Note also that identifying the shoreline can be hindered by the quality of the imagery: although the black-and-white images available for this area in the 1970s and 1980s are high resolution, as indicated by the sharpness of man-made structures, their poor contrast in the marsh, water, and mud-flat areas can be problematic. The images used for shoreline tracing are listed in table 1.

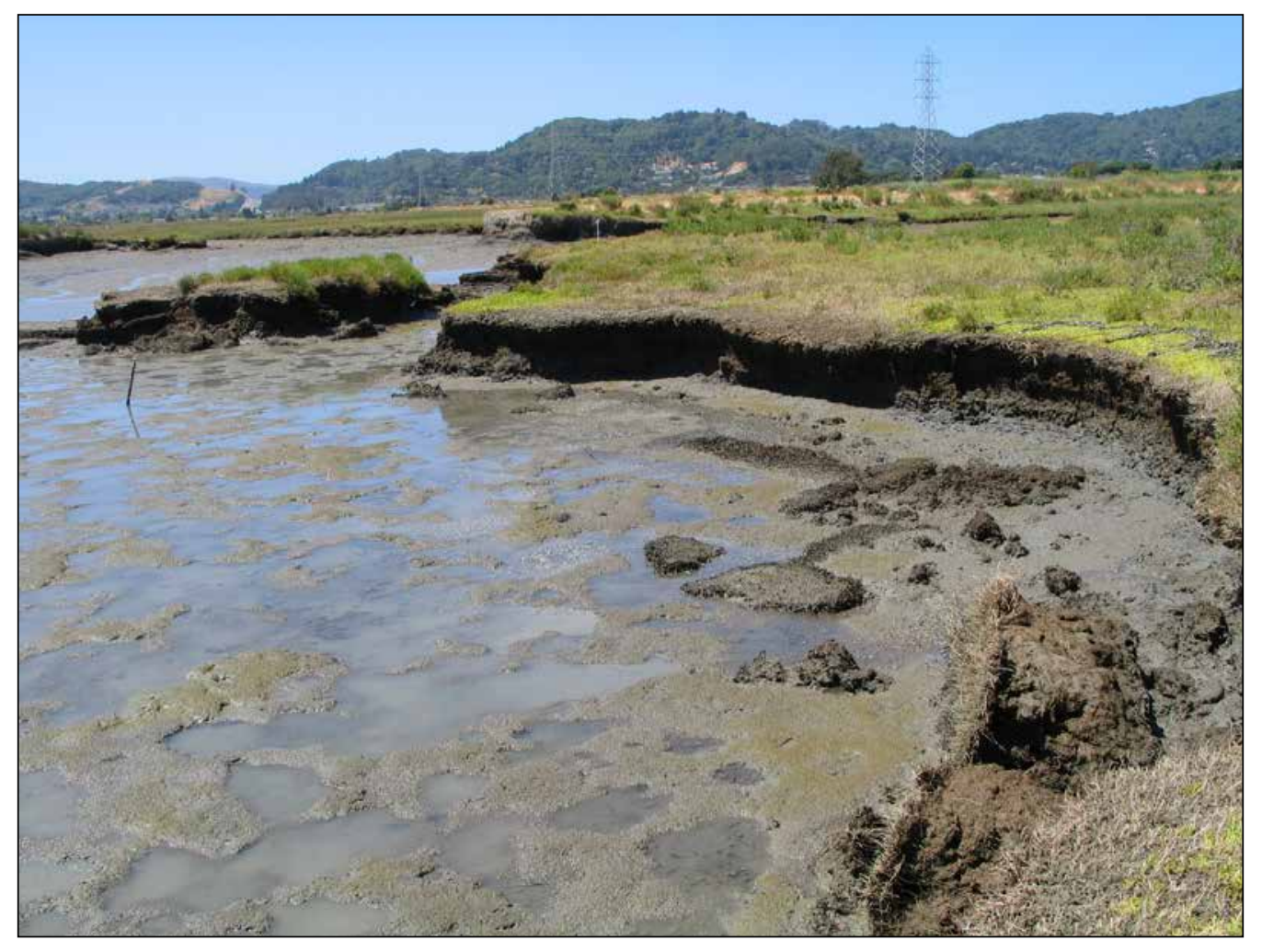

Figure 4. View to southwest, toward mouth of "East Side Outfall Channel," of characteristic shoreline at Heerdt marsh, Corte Madera shoreline, in July 2010, showing steep scarp, vegetated surface and degrading, detached soil blocks. Scarp is about $1 \mathrm{~m}$ high. By 2016, island at upper left had been entirely removed by erosion, as well as point from which this photograph was taken. Photograph by Bradley Carkin, July 2010. 


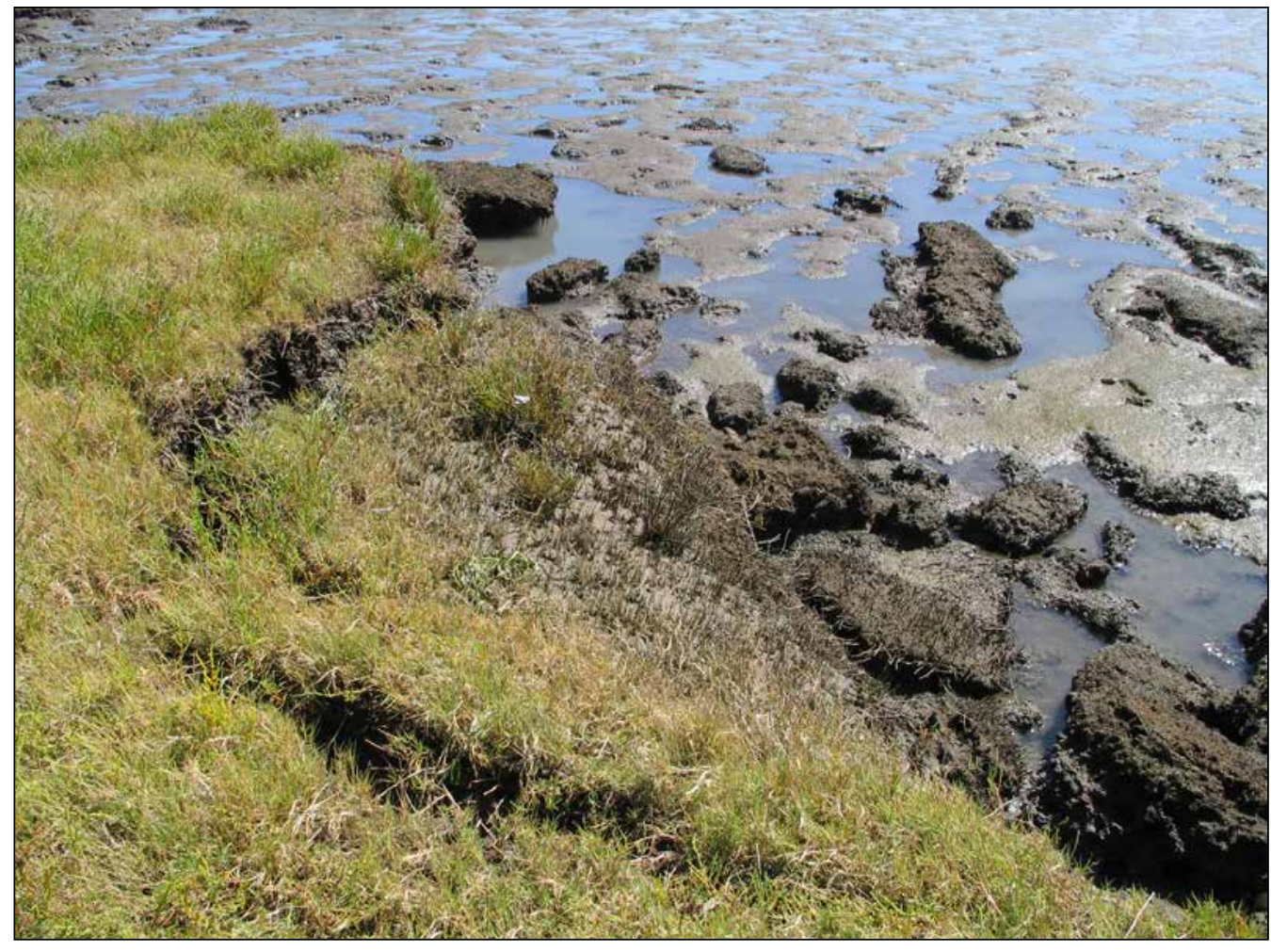

Figure 5. Large, collapsed block of marsh soil at Heerdt marsh, Corte Madera shoreline. Interior fracture at left is about $2 \mathrm{~m}$ from marsh edge. Earlier detached blocks are in varied stages of reduction. Photograph by Bradley Carkin, July 2010.

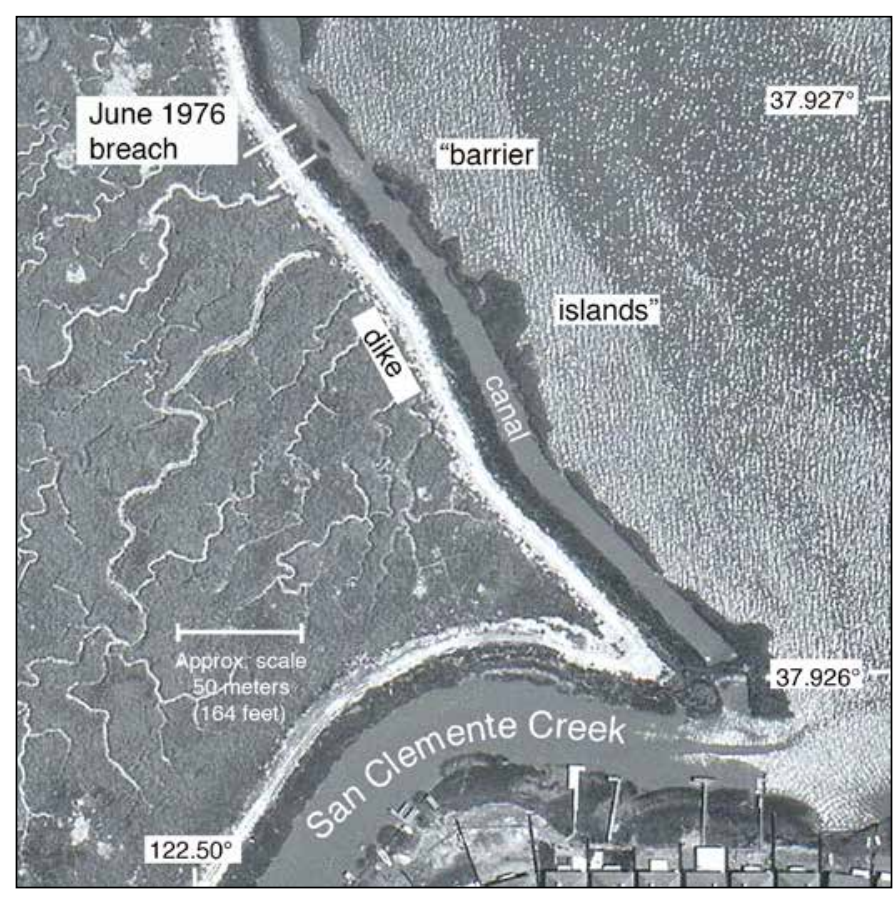

Figure 6. Aerial photograph (ca. 1965) of Muzzi dike and borrow canal at what is now Marta's marsh, Corte Madera shoreline. Some patchy infill or vegetation growth is already visible within canal (between words "barrier" and "islands" on image). Image from Cartwright Aerial Surveys, taken June 12, 1965.

\section{Methods}

High-resolution images from 2002 to 2016 of the entire marsh area were assembled by stitching together screen grabs of the best-quality images available in Google Maps, at scales of between 1:650 and 1:1,300. This scale range corresponds to an image resolution of 0.15 to $0.30 \mathrm{~m} / \mathrm{pixel}$ (resolution calculated from the known dimension of a structure or from other known distances between two points). The compiled images were optimized for contrast and brightness with Adobe Photoshop, and shorelines were traced in Adobe Illustrator. For georeferencing purposes, several varieties of tie points (namely, primary, secondary, and averaged) were created (fig. 2). A set of primary tie points was identified on various made-made features, as close to the ground surface as possible to reduce relief displacement effects, and at distinctive and persistent points of marsh channels. Note that primary tie points, as used here, are equivalent to the secondary control points of Crowell and others (1991) because benchmarks or map-grid ticks are not used. These tie points have variable lifetimes that extend into the past. Because there are no physical structures offshore on which to place tie points on that part of an image, georeferencing of imagery using the rubbersheeting technique tends to be more accurate on the land side, but less so on the water side. This one-sided aspect to the tie-point distribution at the water-land interface hinders bracketing of the shorelines, but it is unavoidable. 
Table 1. Types of, and sources for, imagery used in shoreline studies, Corte Madera shoreline.

[Date of 1853 image is unknown and so is assumed to be July 1. Abbreviations: m, meter(s); yr, year(s); --, not determined]

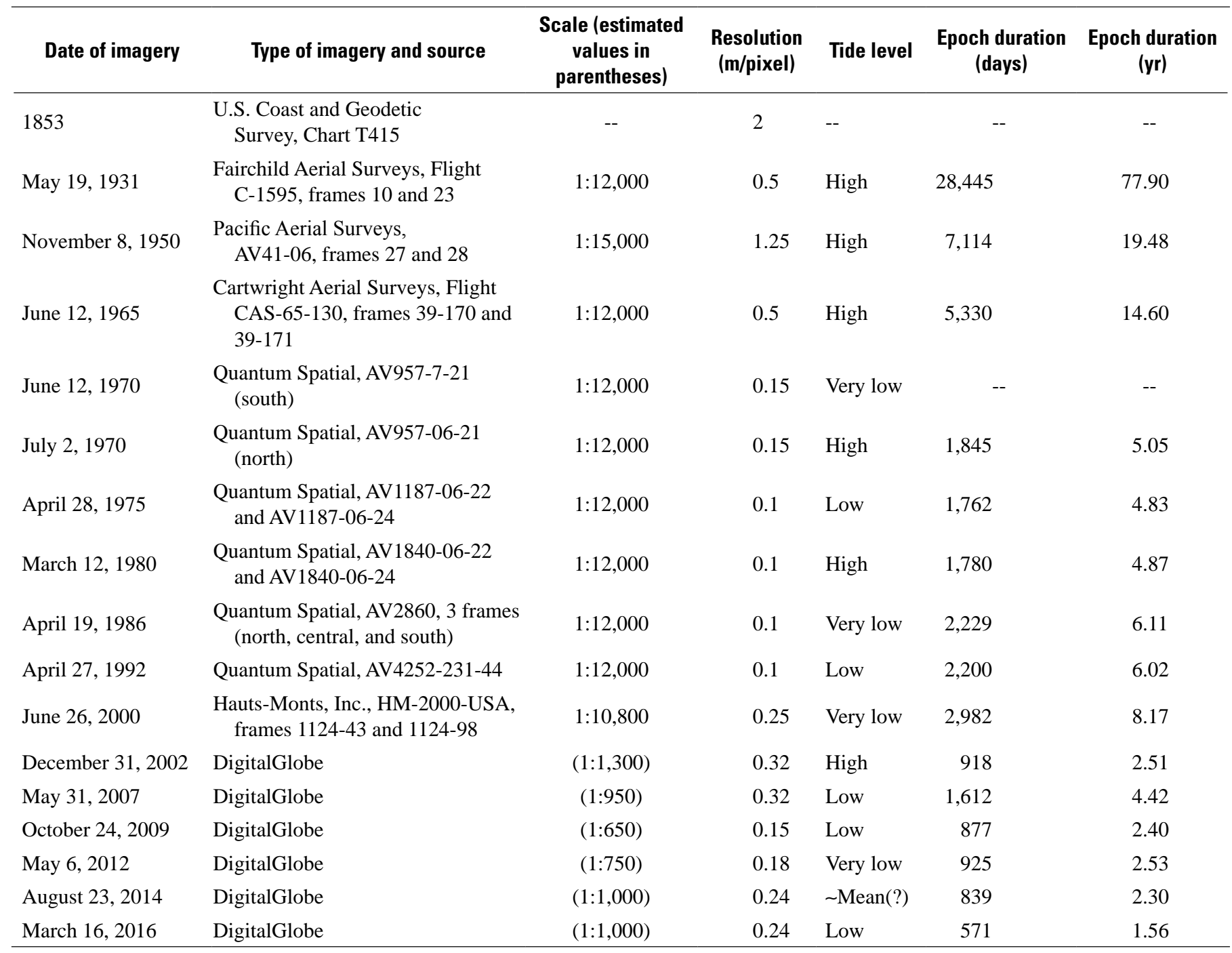

Because older photographs contain progressively fewer cultural features, and because natural features change, two 1965 images (a north-and-south pair) were used together to help anchor earlier photographs, as they contain a useful mix of modern features and intricate details in the still largely unaltered, although diked, marsh area. A secondary set of tie points, common to the 1965 and older photographs, are, therefore, "floating" within the cloud of primary tie points. A small set of tie points, created at the upstream and downstream ends of the three drainage structures through the bay side of the Muzzi dike, are the only identifiable fixed points on the dike that persist for a long time without noticeable movement; these are averaged points, compiled from multiple years because these structures are not visible (owing to high tide) in the Esri World Imagery satellite image used as the source for the primary set of tie points. Note that these averaged points were used in the final rubbersheeting operation, which does a geometric reshaping of the map or image to match tie points.
Shoreline tracings (and the tie points identified as suitable) were exported from Illustrator as Drawing Interchange Format (.dxf) files, then the .dxf files were converted to shapefiles in the geographic information system (GIS) application ArcGIS. Within the GIS, a layer of tie points sourced in the WGS84 (UTM zone 10N) datum was created on the Esri World Imagery satellite image. Tie points in the traced-shoreline shapefiles were snapped to the corresponding tie points on the Esri satellite image, which has a cited absolute-position uncertainty of 0.3 to $0.6 \mathrm{~m}$. Whole-marsh image coverage contains 50 to 64 linked pairs of tie points for each image or rate epoch (epoch as used here is the period in years between two traced shorelines). After all linkages were made, shoreline shapefiles of all epochs were rubbersheeted to the same Esri satellite image to transform the tracings to the map projection, enhancing the relative positioning of the shorelines without using separately orthorectified images for each epoch. Note that the centers of aerial photographs were 
used as much as possible; it is also assumed here that the process of rubbersheeting will override distortions inherent in photography and aerial flight surveys.

For data prior to 2002, aerial photographs and an 1853 map were scanned, optimized in Photoshop, and traced as above. For 1965 to 1986 photographs, two north-and-south images (three for 1986) were used, as noted above. Pixel size of these various source images ranges from 0.1 to $1.25 \mathrm{~m}$ (table 1 ).

All shorelines were appended to the 2016 shoreline in ArcGIS, and the Digital Shoreline Analysis System 4.0 (DSAS) (Himmelstoss, 2009) was used to designate baselines, cast transects, and determine net shoreline movement (NSM) and end point rate (EPR) values. Baselines are starting points for calculating the magnitudes and rates of shoreline change; transects are lines run from the baseline through the shorelines of interest for the calculations.

The great irregularity of the Corte Madera shoreline, together with the desired scale of analysis, creates a problem of maintaining an orthogonal relationship between the shorelines and transects cast in DSAS. Transects cast from a straight baseline always introduce an angle between shoreline pairs that results in NSM and resulting EPR values that are somewhat higher than the actual values. This problem arises from the requirement that, in typical usage, straight transects must cross multiple shorelines, particularly for the calculation of regression statistics, which were not done here.

To eliminate nonorthogonality, baselines are created that are roughly parallel to, and are placed shoreward of, a shoreline (figs. 7A, B). Transects are cast and then individually rotated into the optimal orientation between a pair of adjacent shorelines, which, in this case, is always toward the next older shoreline. Rotation position is determined by eye, but the cosine of very low angles of error is essentially one. Because the shoreline pairs generally are not parallel at each transect, the transect may be oriented to give the shortest distance or, if highly nonparallel, be positioned to cross just one shoreline, to be counted but not used for data. After the measurements are run, the baseline is moved and adapted for the next older shoreline; a new set of transects is then cast, and the process is repeated. Note that, although all the baselines and transects for each measured epoch and calculation zone are not shown, the baselines that generally parallel the shorelines are shown in the measurement zones depicted in figures $1-1,2-1,3-1,4-1$, $5-1$, and $6-1$ (in appendixes 1 through 6 ); tables $1-1,2-1$, $3-1,4-1,5-1$, and $6-1$ (also in appendixes 1 through 6) list the lengths of each baseline, the numbers of transects cast, and the spacings of the transects.

Comparison of EPR values that were computed from transects cast from straight baselines across all shorelines with EPR values computed from optimized transects for shoreline pairs in three measurement zones (Heerdt marsh-2, Marta's marsh, and north Muzzi [north]) reveals a 21 to 25 percent rate "excess" value for nonorthogonal transects. This excess value is almost 48 percent for Triangle marsh.

\section{Rate Uncertainties}

Three principal sources of uncertainty can be identified in this shoreline analysis: digitizing (tracing) errors, shoreline-interpretation uncertainties, and georeferencing

\section{A. Nonorthogonal transects}

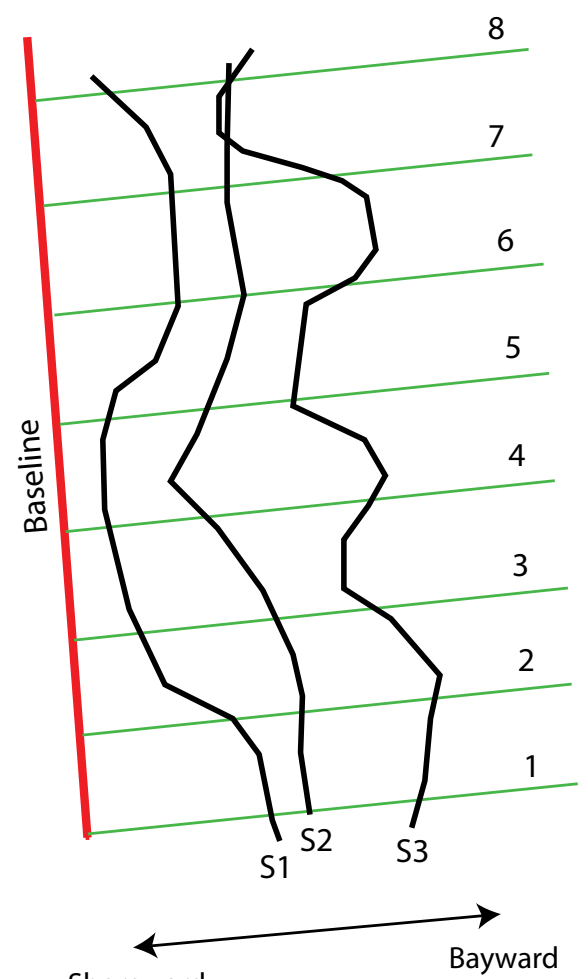

\section{B. Orthogonal transects}

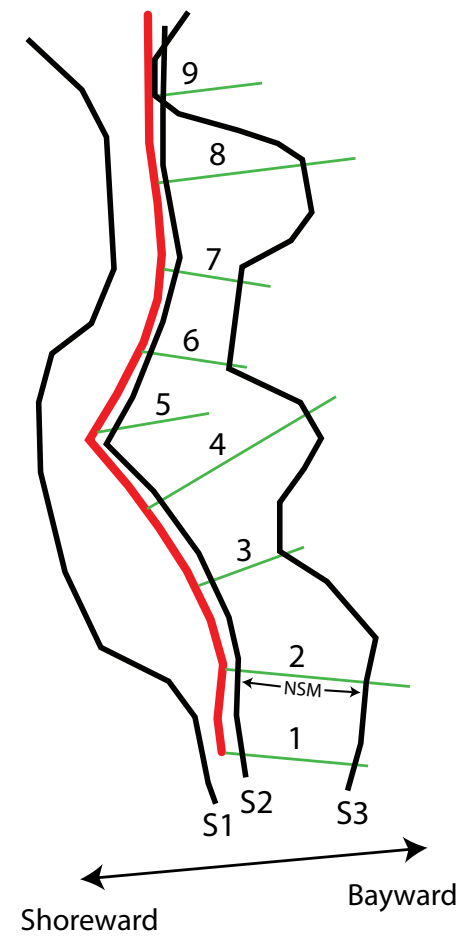

Figure 7. Diagrams showing nonorthogonal versus orthogonal shoreline-transect relations for three irregular shorelines (S1, S2, S3) at Corte Madera shoreline. Green lines are transects. $A$, Nonorthogonal shoreline transects. For shorelines S1 and S2, net shoreline movement (NSM) values calculated at transects 1,6 , and 7 are acceptable, but those calculated at transects $2,3,4,5$, and 8 are excessive. $B$, Orthogonal shoreline transects. Transect 5 is example of transect that cannot be rotated to suitable orthogonal orientation; by crossing one shoreline (S2), it will be counted, but it will be recorded as "null" value and, thus, will not be part of compilation of NSM or end point rate (EPR) values. Transect 9 yields positive NSM value and would be characterized as "accretion," but given predominantly irregular and eroding character of Corte Madera shoreline, crossing will be considered an error owing to tracing, to georeferencing, and (or) to rubbersheeting effects; therefore, NSM value will not be used. 
errors. Digitizing errors are in the tracing of the shoreline and are influenced by factors such as image scale, sharpness, and contrast, as well as using black-and-white versus color images (color images allow for easier distinction between vegetated and nonvegetated areas). A shoreline in the best conditions can generally be well located and digitized within two or three pixels, which is equivalent to a $1.0 \mathrm{~m}^{2}$ area in the 2000 to 2016 imagery.

Shoreline-interpretation uncertainties involve identification of the shoreline, particularly near the former borrow canal for the Muzzi dike and also when using older aerial photographs (that is, 1931 or 1950 vintage). Note that such uncertainties may not be as quantifiable as digitizing errors. Following rubbersheeting and appending in ArcGIS, a transect of shoreline tracings sometimes yields an apparent positive (accretion) value. Such spot accretion or "microaccretion" in an overall-eroding environment is not considered to be real and can be attributed to the uncertainties as described, as well as rubbersheeting. Such positive (accretion) values in the DSAS results are not used for the calculation of rates and averages for each epoch in each zone. Other transects not used are those that are located in constricted shoreline areas and that cannot be rotated to produce a suitable orthogonal orientation (fig. 7). Both situations can result in as much as 50 percent of the transects for some epochs being deleted.

Georeferencing errors as used here involve the ability to accurately colocate points on the source images with the same points on the Esri World Imagery reference image that served

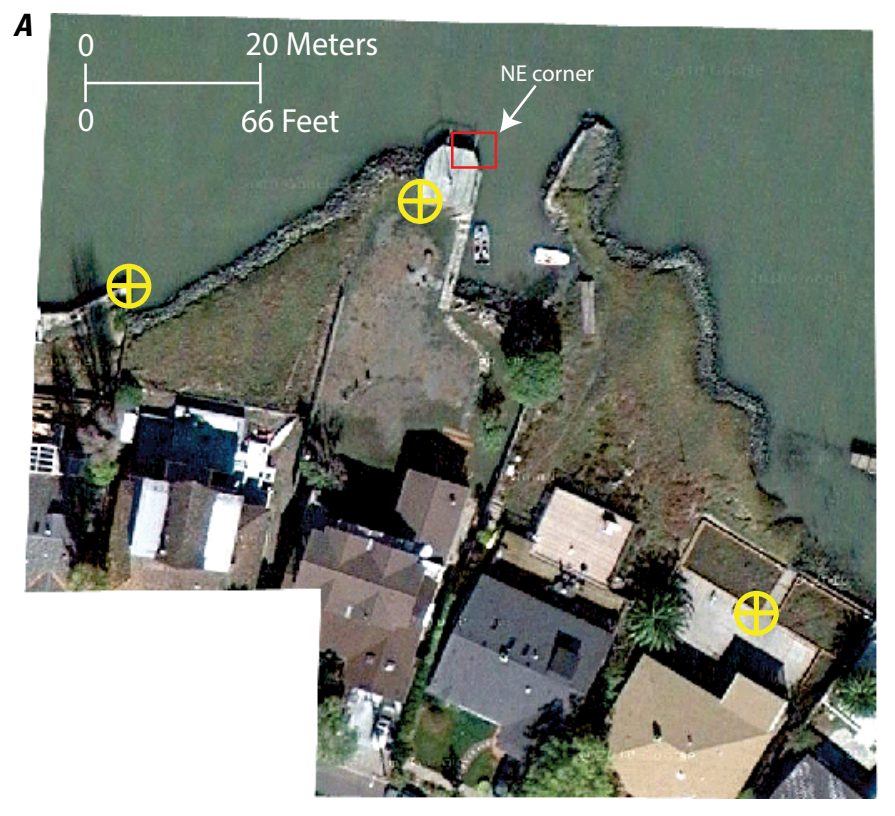

as the base image for map projection. Georeferencing errors are similar to tracing errors and are also influenced by image quality and resolution, but errors are minimized by using the same Esri base image for all shorelines.

The accuracy of the georeferencing and rubbersheeting processes can be assessed by looking at the positional dispersion of recognizable points on shoreline tracings, across multiple shoreline epochs. The corners of the seawalls that are part of the shoreline in the Mariner Cove subdivision of Corte Madera are good candidates for such an assessment. The 13 corners, which are distributed along a shoreline about $180 \mathrm{~m}$ long, are visible on the 1965 to 2016 images. Note that the corners do change over time as properties (lots) evolve, and not all shorelines are present at all corners (several such corners are shown in figs. 8A, 8B, 9; see also, table 2). Note also that the 13 corner points are not tie points; their final georeferenced locations represent the aggregate of all uncertainties related to image quality, tracing errors, and the rubbersheeting process. This is an empirical approach and makes no assumptions regarding the biases and uncertainties among the datasets. Nevertheless, an average divergence of $0.4 \mathrm{~m}$ for colocation of the corner points (that is, from where the points should have been) corresponds closely to the cited absolute positional error of 0.3 to $0.6 \mathrm{~m}$ for orthorectified Esri World Imagery images, but absolute positional error is not considered here.

As Anders and Byrnes (1991) discussed, confidence in rate determinations is greater when the absolute magnitude of shoreline movement exceeds the combined potential map

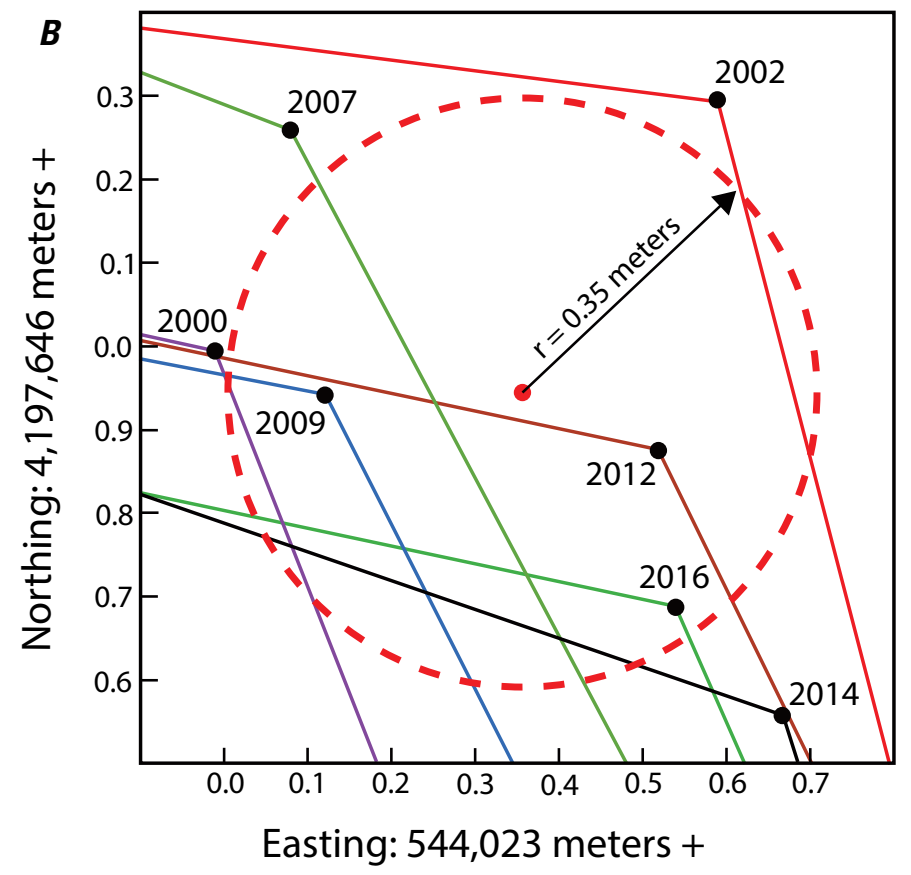

Figure 8. Example of georeferencing of imagery used for study at Corte Madera shoreline. $A$, Satellite image of residential deck on modern shoreline of Mariner Cove subdivision in Corte Madera. Red box outlines corner no. 1 at northeast corner (see table 2; see also, fig. 9). Yellow circles show nearest three primary tie points (registration points) used for georeferencing. $B$, Seven shoreline tracings at corner no. 1 of deck in A. Red dot is centroid (northing, 4,197,646.9446; easting, 544,023.3576; WGS84 UTM zone 10N) of averaged locations of corners from seven shoreline tracings; 0.35 - $\mathrm{m}$ radius is average distance of each corner from their averaged centroid. 
errors. In this study, the lowest values of shoreline movement exceed the average deviation by a factor of not less than 1.7 (table 2). For the purpose of estimating uncertainty in EPR values, a similar approach using seawall corners can be used (three such corners are shown in fig. 9).

The seven shorelines in the study area are not colocated (fig. 10A), a consequence of the aggregated uncertainties inherent to each image and the rubbersheeting process. By designating a shoreline as a reference shoreline, the difference

Table 2. Positional variation measured at corners of seawall at Mariner Cove subdivision, Corte Madera.

[Abbreviations: m, meter(s); N, number of shorelines; no., number. Centroid is average position of $\mathrm{N}$ shorelines at each corner]

\begin{tabular}{cccc}
\hline Corner no. & N & Epoch years & $\begin{array}{c}\text { Average distance from } \\
\text { centroid (m) }\end{array}$ \\
\hline 1 & 7 & $2000-2016$ & 0.35 \\
2 & 7 & $2000-2016$ & 0.36 \\
3 & 3 & $1980-1992$ & 0.36 \\
4 & 4 & $1980-2002$ & 0.43 \\
5 & 5 & $1980-2002$ & 0.3 \\
6 & 5 & $2007-2016$ & 0.2 \\
7 & 3 & $1970-1980$ & 0.44 \\
8 & 3 & $1970-1980$ & 0.58 \\
9 & 4 & $1986-2002$ & 0.47 \\
10 & 10 & $1965-2009$ & 0.56 \\
11 & 10 & $1965-2009$ & 0.5 \\
12 & 4 & $2009-2016$ & 0.13 \\
13 & 6 & $2000-2016$ & 0.46 \\
\hline Average & & & 0.40 \\
\hline
\end{tabular}

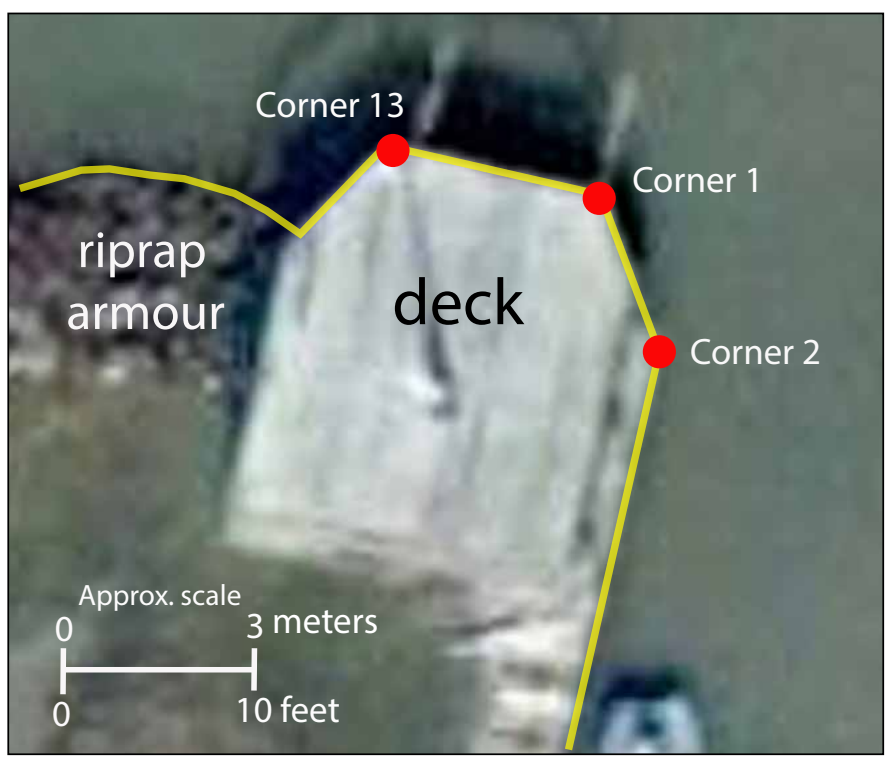

Figure 9. Satellite image showing closer view of residential deck depicted in figure $8 A$ on Corte Madera shoreline; corner nos. 1, 2 , and 13 are labeled. Yellow line shows shoreline as traced for years 2000 to 2016. in the positions of corners on the reference shoreline from those of the same corners on another shoreline is a measure of the positional variation. Four reference shorelines are used for the seawall shoreline, those in the 2016, 2009, 1992, and 1980 imagery. Examples of the measured corner deviations for three deck corners are shown in figure 10B.

Table 3 lists the combined average deviations for the four reference shoreline corners at the 13 corners, a total of 82 separate determinations, providing a measure of deviation

A

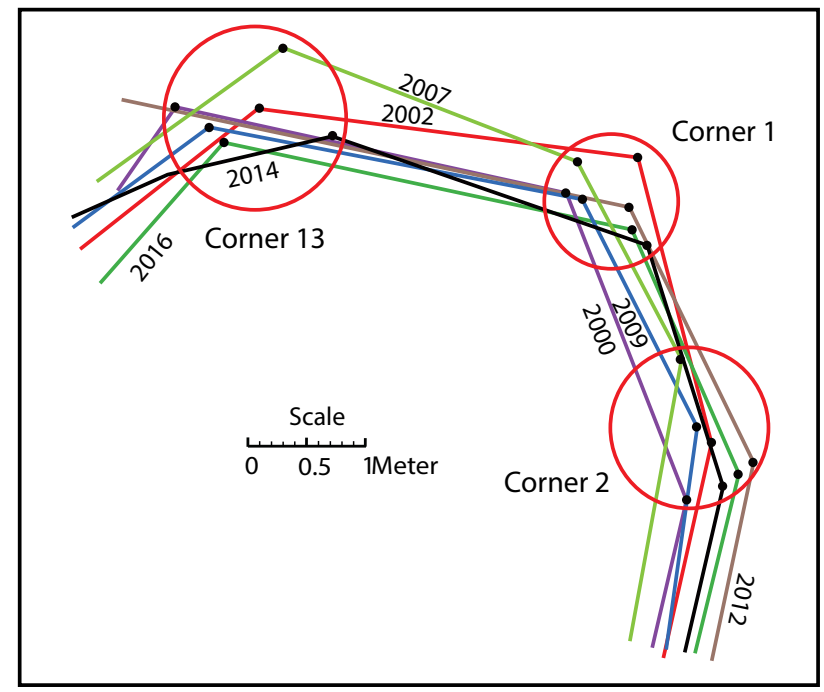

B

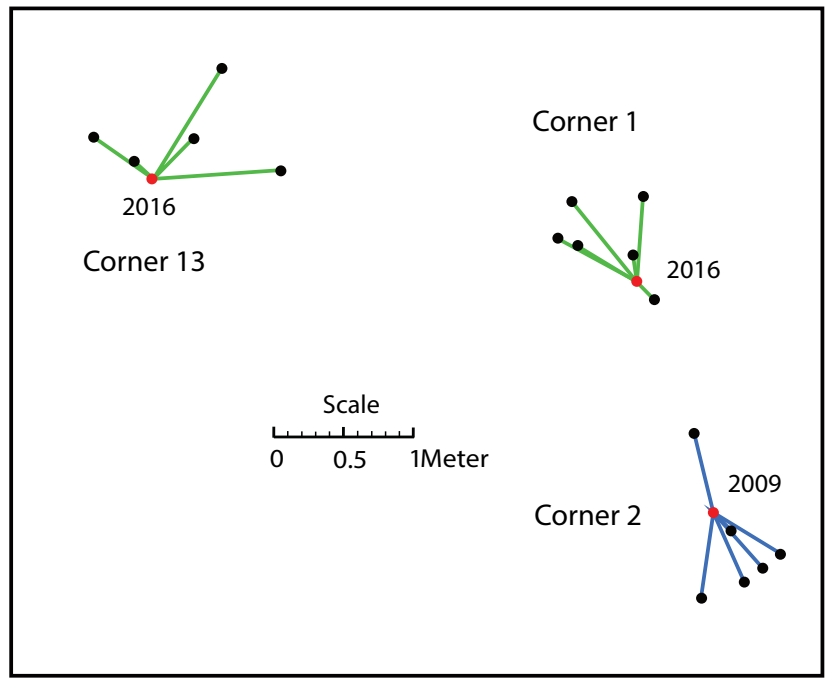

Figure 10. Diagram illustrating positional variations of shoreline at Corte Madera shoreline. A, Black dots show 2000, 2002, 2007, 2009, 2012, 2014, and 2016 positions after rubbersheeting of corner nos. 1, 2, and 13 on residential deck in figure 9. Ideally, all shorelines and corners should be colocated. $B$, Red dots show colocated positions of corner nos. 1, 2, and 13 for years 2016 and 2009; black dots show positions in other study years (see fig. 10A). Green lines illustrate deviations of positions of corner nos. 1 and 13 in study year 2016 from those in other study years (note that corner 13 lacks 2012 corner position); blue lines illustrate deviations of corner no. 2 in study year 2009. 
Table 3. Estimated end point rate uncertainties for epochs from 1965 to 2016, Corte Madera shoreline.

[Abbreviations: $\mathrm{m}$, meter(s); $\mathrm{N}$, total number of deviation values determined (used for average); yr, year(s); --, not determined]

\begin{tabular}{|c|c|c|c|c|c|c|c|c|}
\hline & \multicolumn{4}{|c|}{ Reference years } & \multirow{2}{*}{$\mathbf{N}$} & \multirow{2}{*}{$\begin{array}{l}\text { Average deviation } \\
\qquad(\mathrm{m})\end{array}$} & \multirow{2}{*}{$\begin{array}{l}\text { Epoch duration } \\
\text { (yr) }\end{array}$} & \multirow{2}{*}{$\begin{array}{l}\text { Epoch rate uncertainly } \\
\qquad( \pm \mathrm{m} / \mathbf{y r})\end{array}$} \\
\hline & 2016 & 2009 & 1992 & 1980 & & & & \\
\hline 1965 & -- & 0.78 & -- & -- & 2 & 0.78 & -- & -- \\
\hline 1970 & -- & 0.78 & -- & 0.58 & 4 & 0.68 & 5.05 & 0.20 \\
\hline 1975 & -- & 0.53 & -- & 0.86 & 4 & 0.70 & 4.83 & 0.20 \\
\hline 1980 & -- & 0.55 & 0.53 & & 5 & 0.54 & 4.87 & 0.18 \\
\hline 1986 & -- & 0.72 & 0.39 & -- & 5 & 0.56 & 6.11 & 0.13 \\
\hline 1992 & -- & 0.87 & & -- & 2 & 0.87 & 6.02 & 0.17 \\
\hline 2000 & 0.54 & 0.47 & 0.28 & -- & 11 & 0.43 & 8.17 & 0.12 \\
\hline 2002 & 0.45 & 0.89 & 0.86 & -- & 11 & 0.73 & 2.51 & 0.34 \\
\hline 2007 & 0.81 & 0.48 & -- & -- & 10 & 0.64 & 4.42 & 0.22 \\
\hline 2009 & 0.31 & & -- & -- & 5 & 0.31 & 2.40 & 0.30 \\
\hline 2012 & 0.12 & 0.33 & -- & -- & 8 & 0.23 & 2.53 & 0.15 \\
\hline 2014 & 0.35 & 0.58 & -- & -- & 10 & 0.47 & 2.30 & 0.23 \\
\hline 2016 & & 0.31 & -- & -- & 5 & 0.31 & 1.56 & 0.36 \\
\hline
\end{tabular}

for each year from 1965 to 2016. The rate uncertainty for each epoch of shoreline change (eq. 1) is then found by the quadrature addition of the two epoch-bounding-year averages, divided by the epoch duration (in years):

$$
\begin{aligned}
{\left[U_{p 1_{i}}\right]^{2} \text { and }\left[U_{p 2_{i}}\right]^{2} } & =\text { the shoreline positional uncertainties } \\
\text { for the first-year (year } & \text { ) and second-yea } \\
& \left(\text { year }{ }_{2}\right. \text { ) shorelines, respectively. }
\end{aligned}
$$

The derived end point rate uncertainties for each epoch range from 0.13 to $0.36 \mathrm{~m} / \mathrm{yr}$ (table 3 ).

Uncertainties in the positions of the 1950, 1931, and 1853 shorelines are not well constrained. For georeferencing, a tracing of the 1853 shoreline from a scan of the U.S. Coast and Geodetic Survey map (table 1) and tie points selected at certain topographic features (hilltops, swales, and marsh channels) around the marshland were snapped to the corresponding topographic points on georeferenced copies of U.S. Geological Survey 7.5' topographic maps of San Rafael (ca. 1954) and San Quentin (ca. 1959). Two other maps of this part of San Francisco Bay (informally known as "Corte Madera bay”) that are dated 1884 and 1892 are essentially redrawn versions of the 1853 map and, thus, are not considered useful. On the 1853 map, only the largest channels (Shorebird channel, "Salt Marsh creek,” and San Clemente Creek) resemble those seen in later photographs and maps.

\section{Results}

The values of net shoreline movement (NSM) and the corresponding end point rate (EPR) values for each epoch vary widely owing to the irregular nature of the shorelines.
For measurements and calculations, the "Corte Madera bay" shoreline is subdivided into separate zones (fig. 2) that are bounded by the locations of past or present channels and dikes, as well as by the extent of human disturbance. The aerial extents of the rate-calculation zones are shown in appendixes 1 through 6 (see figs. 1-1, 2-1, 3-1, 4-1, 5-1, 6-1).

The trends in EPR values for each epoch and zone are plotted in appendixes 1 through 6; the 1-sigma range of EPR variation for each epoch, and the long-term average EPR values for each zone, are delineated on the rate plots (figs. 1-2, 1-3, 1-4, 1-5, 1-6, 1-7, 1-8, 1-9, 2-2, 3-2, 4-2, $5-2$, and 6-2, in appendixes 1 through 6). The specifications and tabulated results are given tables $1-1,2-1,3-1,4-1,5-1$, and 6-1 (also in appendixes 1 through 6). Table 4 records the average EPR for each of the rate-calculation zones, with an average of the seven rate-calculation zones for Heerdt marsh reported; note that a historical period from 1853 to 1931 records rates before the availability of photographs and satellite imagery.

\section{Heerdt Marsh}

The Heerdt marsh shoreline (fig. 1-1, in appendix 1) extends from the end of armoring on Corte Madera Creek (at the east end of the Greenbrae boardwalk; lat $37.942^{\circ}$ N., long $122.507^{\circ} \mathrm{W}$.) to the mouth of the "East Side Outfall Channel" (lat $37.9371^{\circ} \mathrm{N}$., long $122.505^{\circ} \mathrm{W}$.). Overall rates of change determined for this shoreline reflect conditions that are the least disturbed by human influence, both where facing the bay and where it is more protected on Corte Madera Creek. The average retreat rate of the shoreline that faces the bay is $0.52 \mathrm{~m} / \mathrm{yr}$ from 1931 to 2016. From 1992 to 2016, the average is essentially identical, at $0.48 \mathrm{~m} / \mathrm{yr}$; in the same time period, the nonarmored south shoreline of Corte Madera Creek retreated more slowly, 
Table 4. Historical and modern end point rates for rate-calculation zones, Corte Madera shoreline.

[Historical is defined as occurring before photography and satellite imagery were available; modern, occurring when photography and satellite imagery were available. Values shown for Heerdt marsh are averages of seven rate-calculation zones. Note that no imagery was available at Triangle marsh for 1931. Abbreviations: m, meter(s); yr, year(s); --, not determined. Negative values indicate erosion; positive values indicate accretion]

\begin{tabular}{|c|c|c|c|c|c|}
\hline \multirow[b]{2}{*}{ Location } & \multicolumn{5}{|c|}{ End point rates $(\mathrm{m} / \mathrm{yr})$} \\
\hline & $\begin{array}{c}\text { Historical } \\
\text { (1853-1931) }\end{array}$ & $\begin{array}{c}\text { Modern } \\
(1931-2016)\end{array}$ & $\begin{array}{c}\text { Modern } \\
\text { (1931-1965) }\end{array}$ & $\begin{array}{c}\text { Modern } \\
\text { (1965-1992) }\end{array}$ & $\begin{array}{c}\text { Modern } \\
(1992-2016)\end{array}$ \\
\hline Corte Madera Creek & -- & 0.13 & 0.38 & $-0.02 \pm 0.18$ & $-0.37 \pm 0.25$ \\
\hline Heerdt marsh & -0.8 & -0.52 & -0.46 & $-0.59 \pm 0.18$ & $-0.48 \pm 0.25$ \\
\hline North Muzzi marsh (north) & -0.6 & -0.66 & -0.44 & $-0.64 \pm 0.18$ & $-0.70 \pm 0.25$ \\
\hline North Muzzi marsh (south) & -0.8 & -0.76 & -0.38 & $-0.98 \pm 0.18$ & $-0.72 \pm 0.25$ \\
\hline Outer Muzzi marsh & -0.8 & -0.65 & -0.38 & $-0.74 \pm 0.18$ & $-0.62 \pm 0.25$ \\
\hline \multirow[t]{2}{*}{ Marta's marsh } & -0.4 & -0.52 & -0.29 & $-0.55 \pm 0.18$ & $-0.53 \pm 0.25$ \\
\hline & $\begin{array}{c}\text { Historical } \\
\text { (1853-1950) }\end{array}$ & $\begin{array}{c}\text { Modern } \\
(1950-2016)\end{array}$ & $\begin{array}{c}\text { Modern } \\
(1950-1965)\end{array}$ & $\begin{array}{c}\text { Modern } \\
(1965-1992)\end{array}$ & $\begin{array}{c}\text { Modern } \\
(1992-2016)\end{array}$ \\
\hline Triangle marsh & -0.6 & -0.35 & -0.33 & $-0.32 \pm 0.18$ & $-0.37 \pm 0.25$ \\
\hline
\end{tabular}

averaging $0.36 \mathrm{~m} / \mathrm{yr}$. The armoring, placed between 1986 and 1992, is having a considerable protective effect as the adjacent nonarmored shoreline retreats southward. It is worth noting that the wake from the Larkspur Ferry has not resulted in a retreat value for the unprotected Corte Madera Creek shoreline that exceeds what is occurring on the bay-facing shoreline of Heerdt marsh: at the northeast corner of Heerdt marsh, an eastwest-directed retreat of $48 \mathrm{~m}$ has taken place since 1931; since 1853, it has been about $118 \mathrm{~m}$.
Localized accretion that acquired a semipermanent, vegetated surface is identified in two protected areas: along the south side of Corte Madera Creek (near its mouth; see fig. 11), and at the mouth of Shorebird channel (fig. 12). Infilling within a small embayment on Corte Madera Creek caused the shoreline to advance northward from 1931 to the mid-1970s. The shorelines visible in photos from 1970, 1975, and 1980 lack the distinctive, irregularly shaped margin typical of a bay-facing shoreline, but, beginning in 1986, a sharp, vegetated margin
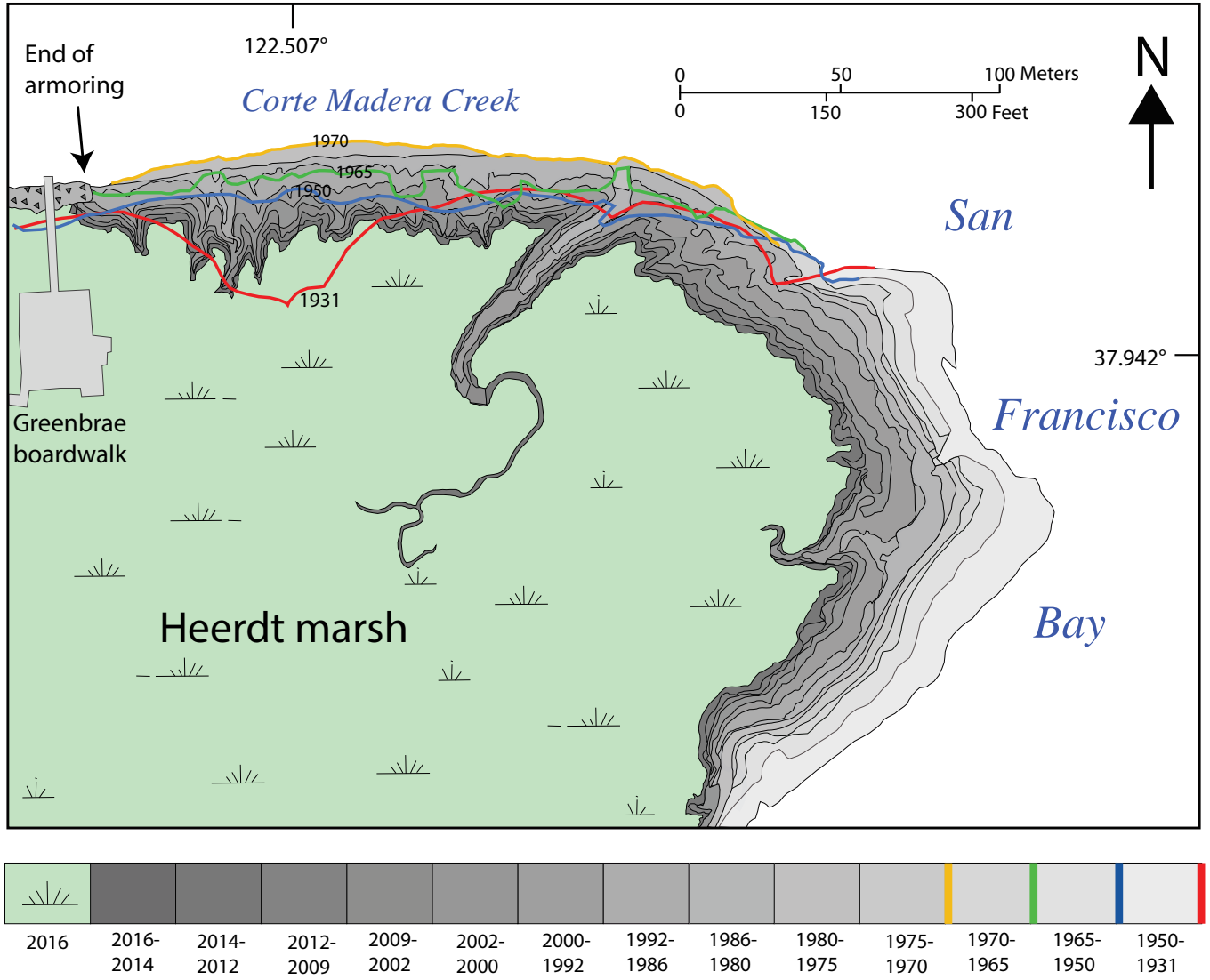

Figure 11. Map of shoreline change at northern part of Heerdt marsh, Corte Madera shoreline. Shades of gray show amounts of erosion during study years beginning in 1931; colored lines show position of south shoreline of Corte Madera Creek in 1931 (red), 1950 (blue), 1965 (green), and 1970 (yellow). Northward accretion filled embayment on shoreline of Corte Madera Creek. Note that armoring (triangle pattern) along Corte Madera Creek ends at last residence on Greenbrae boardwalk. 

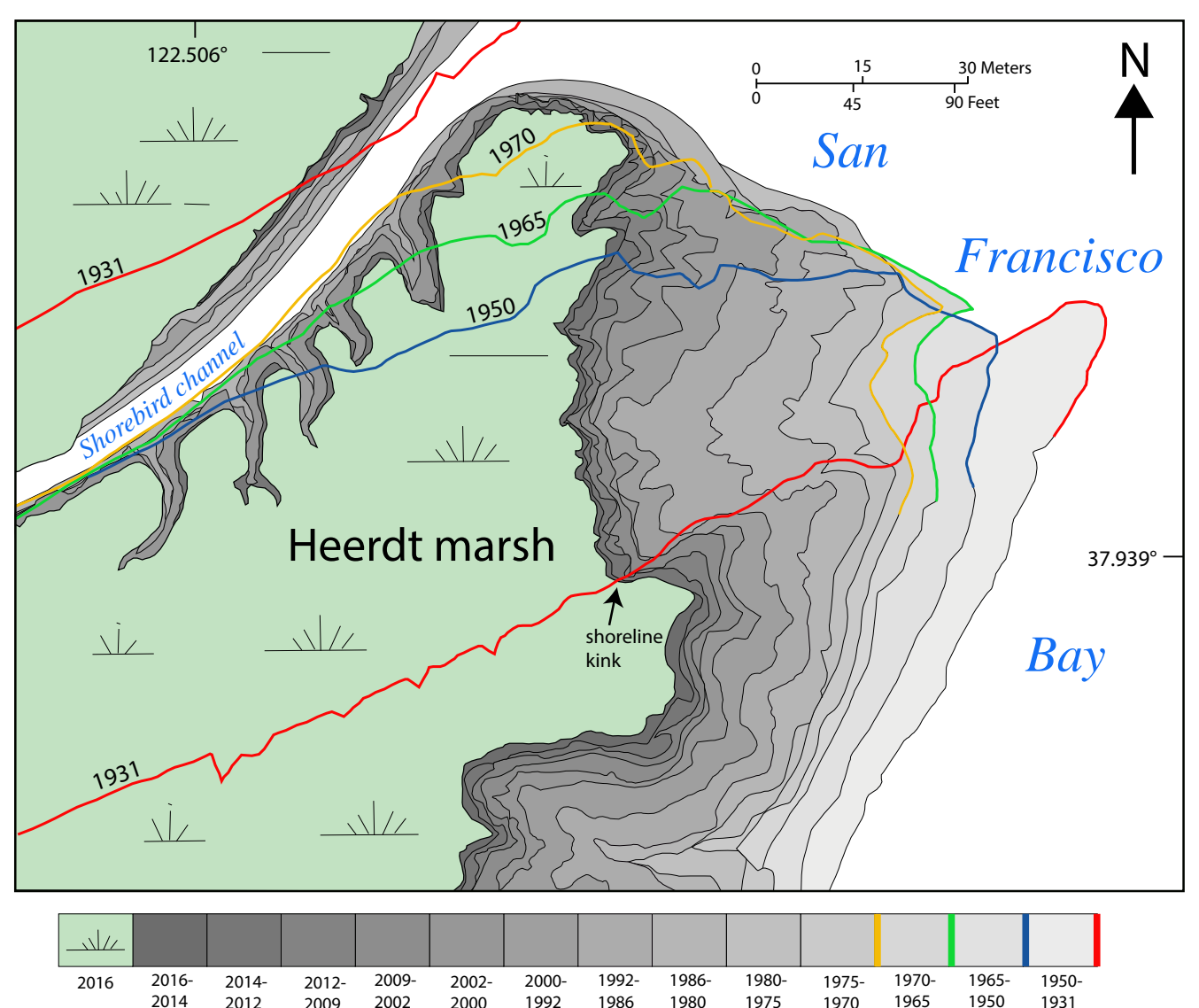

Figure 12. Map of shoreline change at mouth of Shorebird channel at Heerdt marsh, Corte Madera shoreline. Shades of gray show amounts of erosion during study years beginning in 1931; colored lines show positions of shoreline in 1931 (red), 1950 (blue), 1965 (green), and 1970 (yellow). and a distinct scarp had developed. Also at that time, a series of narrow, erosional embayments began forming, extending southward into the previously accreted sediments; however, much of the accreted land since 1931 has eroded away.

Severed from its upper reaches by construction of the railroad bed in 1875, the now oversized and underfit Shorebird channel has since largely filled in with sediment. The east termination of the area of channel infilling forms an accreted area that advanced northward from 1931 into the 1970s (fig. 12), at which time it established a pseudoequilibrium in its northward extent, while the bay-facing shoreline retreated.

A kink in the shoreline along the south shore of the Shorebird channel aligns with the position of the 1931 shoreline (fig. 12) and reflects, evidently, the greater resistance of older and firmer marsh sediment at the former shoreline of the channel. Since 1931, channel infilling has consolidated, becoming vegetated and elevated through vertical accretion. Retreat rates in the bay-facing and eroding infilling exceeded $1 \mathrm{~m} / \mathrm{yr}$ between 1980 and 1992; during this time, a series of six narrow, but growing erosional embayments (see fig. 11) developed in previously accreted sediments on the protected shoreline within the channel, similar to the process on Corte Madera Creek.

The averaged modern retreat rate of the seven shorefacing rate-calculation zones (see fig. 1-1, in appendix 1) for Heerdt marsh is $0.52 \mathrm{~m} / \mathrm{yr}$ (fig. 13). A spike in rates that is evident in the 2000 to 2002 epoch also appears variably in other rate-calculation zones on the Corte Madera shoreline.

\section{North Muzzi Marsh—North and South Sections}

The entire shoreline of north Muzzi marsh (fig. 2) is an eroding dike, originally nearly $800 \mathrm{~m}$ long, bounded on the north at the mouth of the "East Side Outfall Channel" (lat $37.9371^{\circ} \mathrm{N}$., long $122.505^{\circ} \mathrm{W}$.) and to the south by a dike and channel at the northern margin of outer Muzzi marsh (lat $37.9304^{\circ} \mathrm{N}$., long $122.5038^{\circ} \mathrm{W}$.). For rate-calculation purposes, the dike is divided into a north and a south section (see figs. 2-1 and 3-1 [in appendixes 2, 3], respectively), separated at the location of a June 1976 breach (lat 37.9319 N., long $122.5047^{\circ}$ W.).

Spikes in rates during the 1965 to 1970 epoch and the 1986 to 1992 epoch (figs. 2-1 and 3-2 [in appendixes 2, 3], respectively) reflect shoreline advancement across the former borrow canal in different areas along the dike, determined by the width or durability of the "barrier islands.” By 1992, much of the influence of the borrow canal had ended, and erosion began acting directly on the dike along its entire length.

Erosion in two places through the north section of the north Muzzi marsh dike amounts to about 15 percent of its length. Average recent retreat rates along the $600 \mathrm{~m}$ of shoreline in the "post canal" period (from 1992 to 2016) is $0.70 \mathrm{~m} / \mathrm{yr}$, about 46 percent higher than the Heerdt marsh average during the same period.

The south section of the north Muzzi marsh shoreline (fig. 3-1, in appendix 3), which contains about $230 \mathrm{~m}$ of present-day shoreline, has experienced the most extensive 


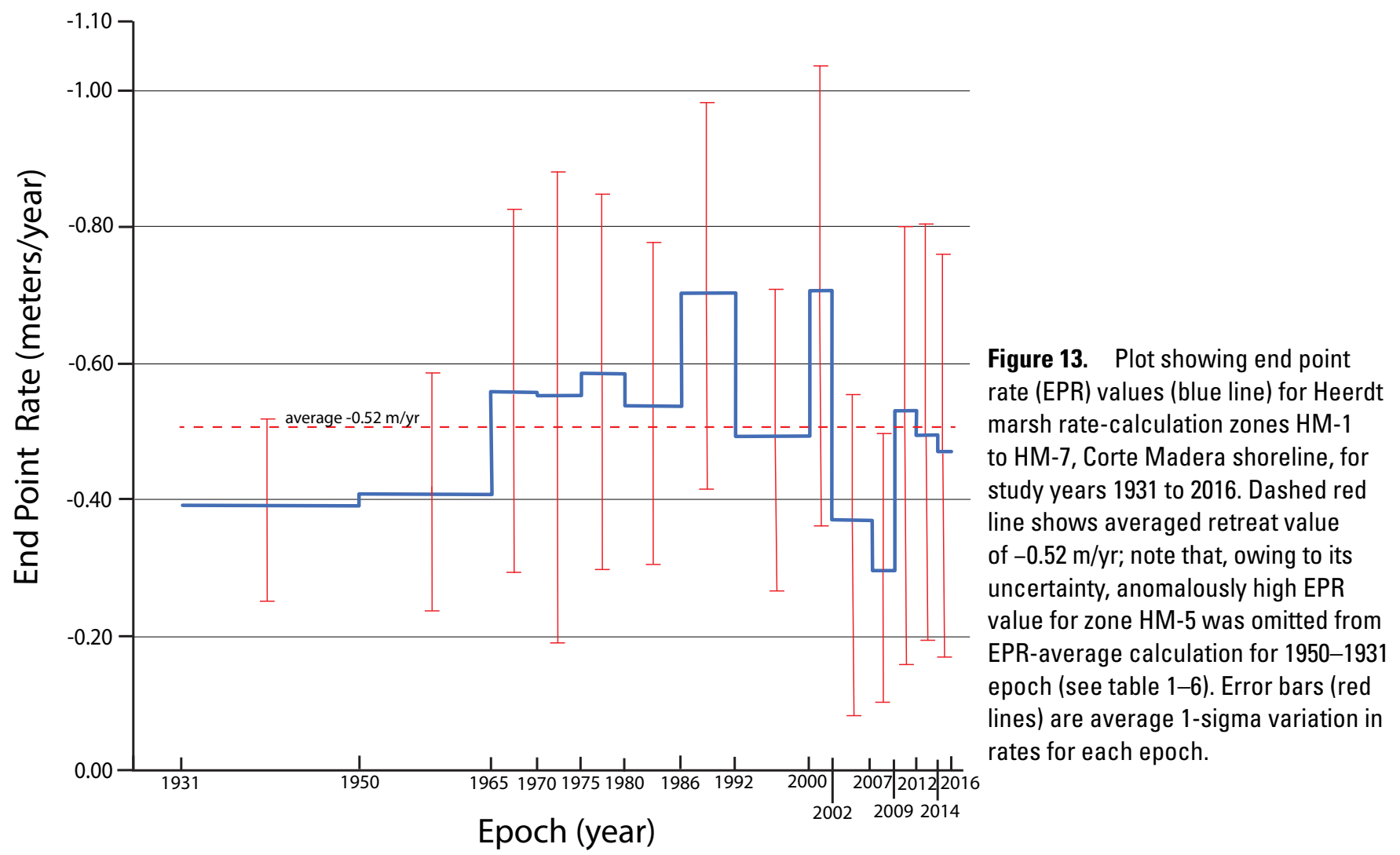

erosion on the entire Corte Madera shoreline. A northeastsouthwest-directed retreat value of about $112 \mathrm{~m}$ of the shoreline projection (see fig. 14) for the modern period of 1931 to 2016 is the greatest at the Corte Madera shoreline, a long-term rate of $1.3 \mathrm{~m} / \mathrm{yr}$. Average recent retreat rates along the $230 \mathrm{~m}$ of shoreline of the south section in the "post canal" period (from 1992 to 2016) is $0.72 \mathrm{~m} / \mathrm{yr}$, similar to that of the north section. Figure 14 reveals retreat underway through a series of collapsed marsh blocks (visible in 1992 image; fig. 14B), in variable states of diminution; the measured retreat rate for the area of these collapsed blocks during the 1986 to 1992 epoch is $1.1 \mathrm{~m} / \mathrm{yr}$.

\section{Outer Muzzi Marsh}

Outer Muzzi marsh (fig. 4-1, in appendix 4) is presently a revitalized and eroding natural marsh, bounded on the north near a 1976 breach (lat $37.9304^{\circ} \mathrm{N}$., long $122.5038^{\circ} \mathrm{W}$.) in the former 1959 dike and on the south by another breach (lat $37.9275^{\circ} \mathrm{N}$., long $122.5023^{\circ} \mathrm{W}$.). The 1959 bounding dike, about $365 \mathrm{~m}$ long, has been entirely removed by erosion since about 2012. Following the breaching of the dike in 1976 in two places, mud flats advanced rapidly inland, surrounding the points of breaching. This advancement was probably later accelerated in 1981 by channel enlargement on the periphery of the inner and outer Muzzi marshes (Faber and others, 1988). It was not until the 1986 to 1992 epoch that a vegetated surface stabilized and a definitive shoreline formed interior to the breach areas, a shoreline that also continued to retreat. These interior areas were not measured during this study.
The modern (1931 to 2016) end point rate for outer Muzzi marsh is $0.65 \mathrm{~m} / \mathrm{yr}$. During this period, higher rates took place between 1980 and 1992 as the shoreline advanced across the borrow canal (fig. 4-2, in appendix 4).

\section{Marta's Marsh}

The shoreline at Marta's marsh (fig. 15; see also, fig. 5-1, in appendix 5) is an eroding dike, about $250 \mathrm{~m}$ long, bounded on the north by a June 1976 breach (lat $37.9275^{\circ} \mathrm{N}$., long $122.5023^{\circ} \mathrm{W}$.) and on the south by the mouth of San Clemente Creek (lat $37.9255^{\circ} \mathrm{N}$., long $122.5004^{\circ} \mathrm{W}$.). The dike has eroded through in two places, amounting to about 20 percent of its length. Imagery for 1931 does not cover the entire length of the marsh. Narrower barrier islands along the southern part of the shoreline eroded away first, causing the first, brief pulse of two "canal jump" increases of end point rate values (see fig. 5-2, in appendix 5). The average "post canal" retreat rate between 1992 and 2016 is $0.53 \mathrm{~m} / \mathrm{yr}$, intermediate between the higher rates for the outer and north Muzzi marshes to the north and a lower rate at Triangle marsh to the south.

\section{Triangle Marsh}

Triangle marsh gets its name from the shape of an isolated, 4.5-ha triangular remnant (see fig. 6-1, in appendix 6) of natural marsh whose eroding shoreline is centered at lat $37.9227^{\circ} \mathrm{N}$., long $122.4959^{\circ} \mathrm{W}$. A berm remnant and former dredged channel separate the marsh from the Mariner Cove 

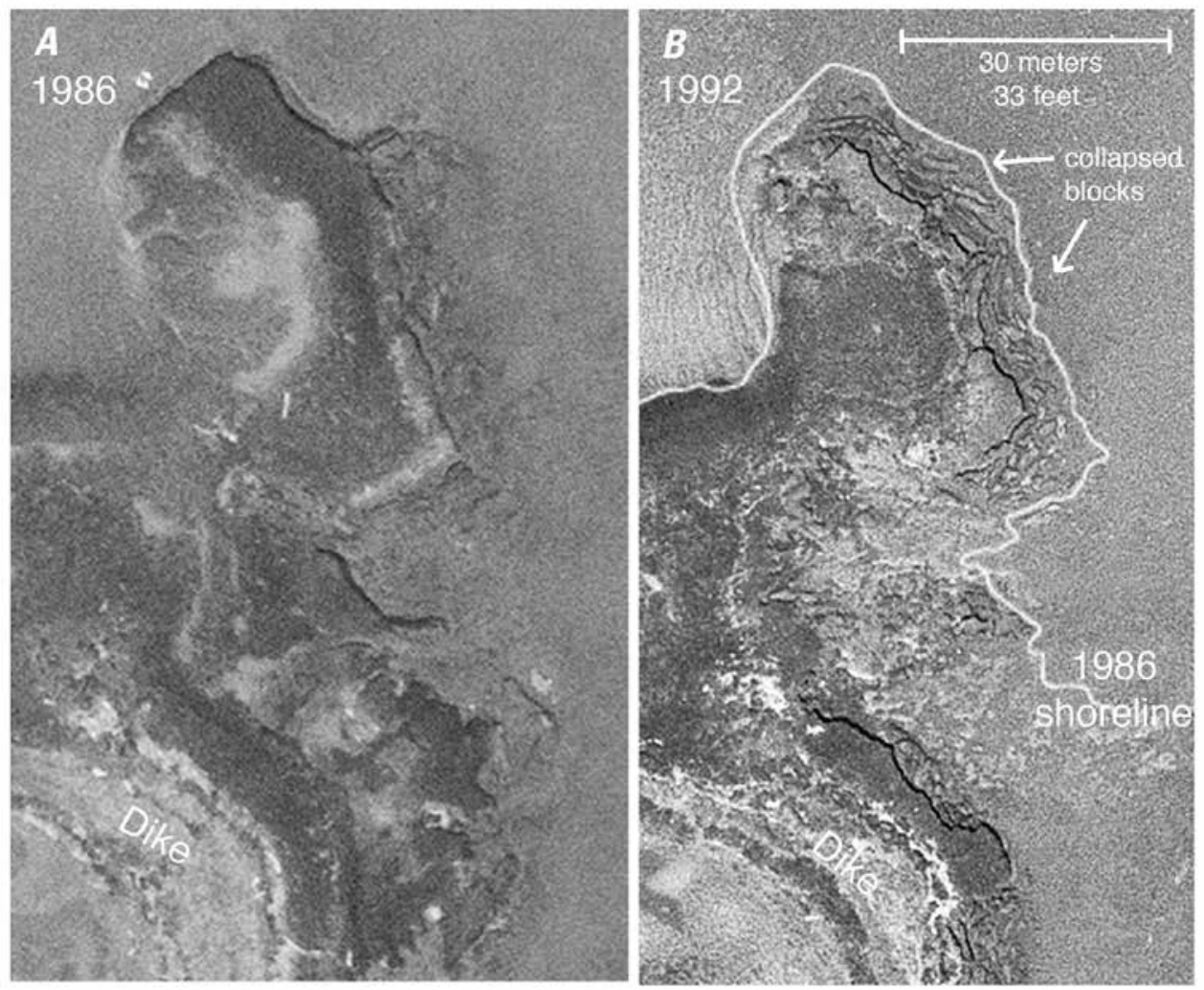

Figure 14. Aerial photographs of part of north Muzzi marsh (south) near mouth of former "Salt Marsh creek," Corte Madera shoreline, showing shoreline changes. $A$, Image of shoreline in 1986. $B$, Image of shoreline in 1992. Arrows highlight succession of collapsed soil blocks formed within six-year 1986-1992 epoch along eastnortheastern margin of peninsula.
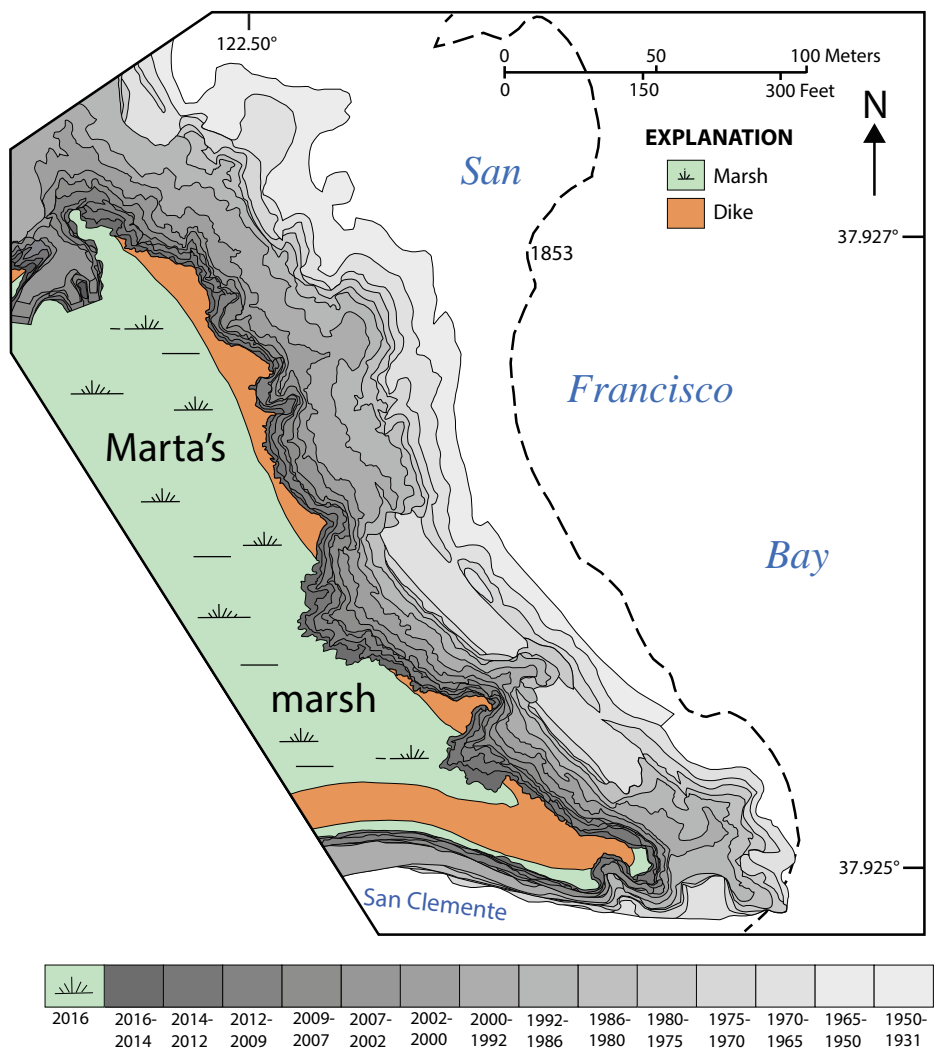

Figure 15. Map of shoreline change at Marta's marsh, Corte Madera shoreline. Shades of gray show amounts of erosion during study years beginning in 1931; dashed black line shows approximate location of 1853 shoreline. subdivision. A narrow, 200-m-long southeastern projection of adjacent shoreline was not examined. Imagery for 1931 was not available for Triangle marsh. Similar to Heerdt marsh, Triangle marsh records the rates of a shoreline that has experienced the least amount of human impact. The retreat rate from 1992 to 2016 is $0.37 \mathrm{~m} / \mathrm{yr}$, the lowest rate on the bay-facing Corte Madera shoreline.

Also discernable at Triangle marsh is the increasing irregularity of the shoreline from 1950 to the present, which is reflected in the increasing length of the DSAS baselines as an approximation of the shorelines (see fig. 6-1, in appendix 6). Part of the irregularity can be attributed to the eroding shoreline, which intercepts channel meanders in the marsh and opens up additional erosion points. A spike in end point rate values for the 2000 to 2002 epoch is also pronounced.

\section{Discussion}

The Corte Madera shoreline has retreated significantly during the 163 -yr period from 1853 to 2016 . Total shoreline retreat during this period ranges from about 70 to $150 \mathrm{~m}$, which corresponds to a long-term rate of 0.4 to $0.9 \mathrm{~m} / \mathrm{yr}$, depending on the location along the highly irregular shoreline. The maximum retreat approximates the amount of $148 \mathrm{~m}$, as measured by J. Zoulas (U.S. Army Corps. of Engineers, unpub. data, 2006).

Starting about 1965, various points along the diked shoreline began retreating in excess of natural rates as erosion began breaking through the most recently created and 
narrowest "barrier islands," opening up new fronts of erosion along the western margin of the borrow canal. The process culminated during the 1980s in a spike in erosion rates (see figs. 2-1, 3-2, 4-2, and 5-2, in appendixes 2, 3, 4, and 5) between 1980 and 1992 as the shoreline underwent a westward jump across the open water or infill within the borrow canal. These higher rates represent strongly human-influenced effects. The rate jump varied in time and magnitude along the shoreline, depending on the initial width of the islands and the presence of openings that were due to preexisting marsh channels. Breakthroughs in the present-day dike have occurred at the locations of former marsh channels or narrow barrier islands, and they have continued to broaden.

Evidence of enhanced shoreline retreat that is due to the influence of the Muzzi dike borrow canal can be seen figure 16, in which the trends for north Muzzi marshes (north and south) and outer Muzzi marsh show cumulative net shoreline movement values that exceed the trends of Heerdt and Triangle marshes, particularly in the 1986 to 1992 epoch. A "canal jump" is also evident at Marta's marsh, but it was at lower rates and spread over a longer time period.

As determined for the modern period of 1931 to 2016, retreat rates increase toward the central part of Corte Madera shoreline (fig. 17), likely owing to greater wave exposure and perhaps focusing of energy from wave reflection or refraction within "Corte Madera bay." Retreat has also been enhanced by the borrow canal for the Muzzi dike, but this relatively north-south-directed variation in retreat rates is also reflected in retreat rates since 1992, after the effects of the canal had largely ended. As a corollary, the presence of the bay-side Muzzi dike has not reduced the rate of shoreline erosion below that of adjacent areas that are not diked. Areas that have the lowest cumulative retreat (and retreat rates) are at Triangle marsh and at the protected area on Corte Madera Creek (figs. 16, 17).

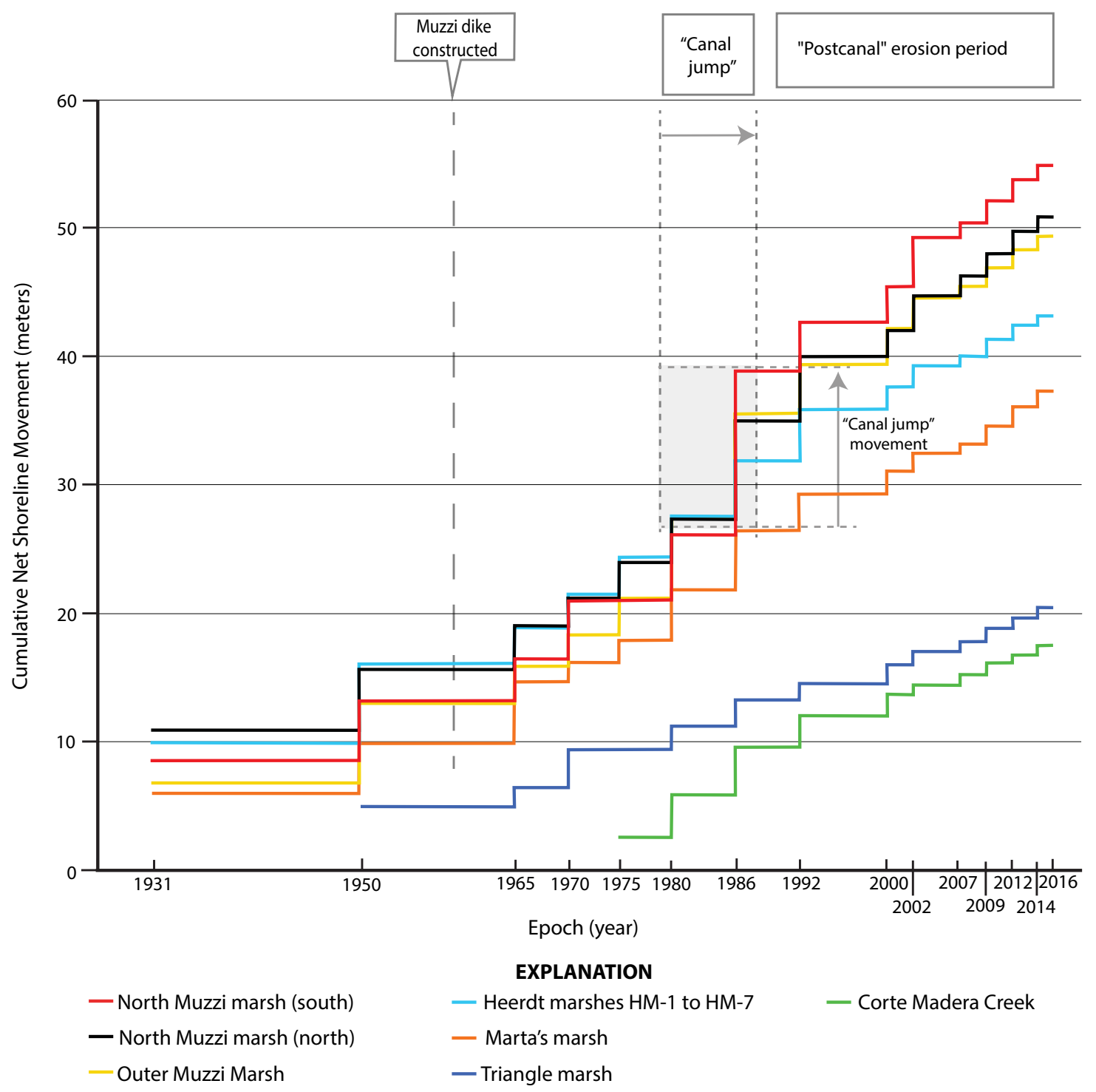

Figure 16. Plots of cumulative net shoreline movement during modern period of 1931 to 2016 for seven shoreline rate-calculation zones, Corte Madera shoreline. 


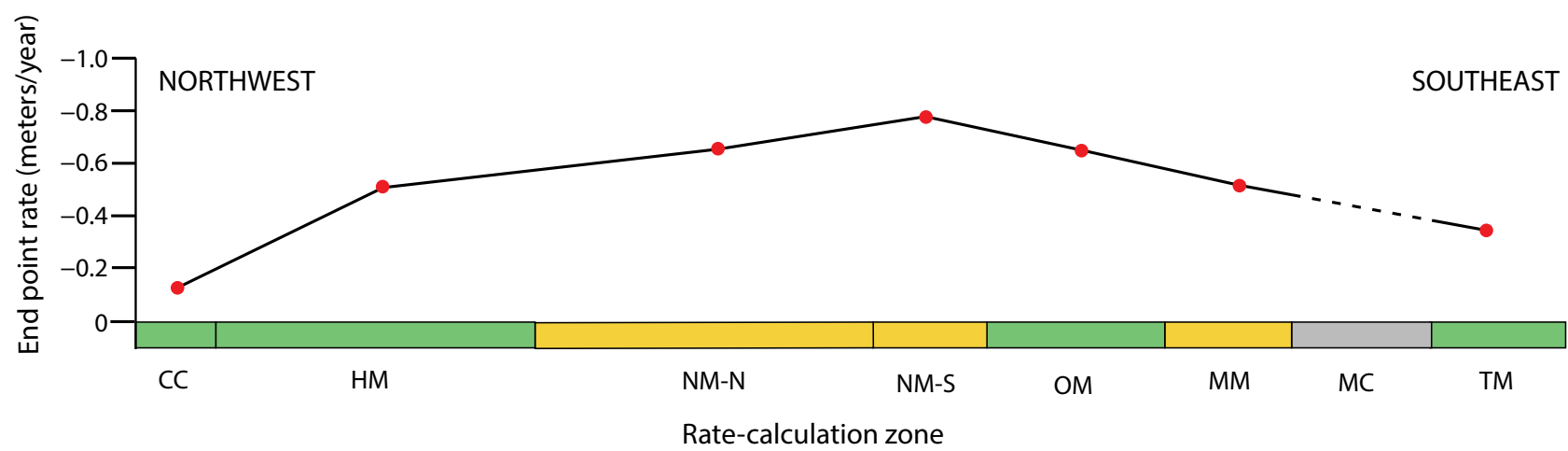

Figure 17. Variations in average end point rate values (red dots) along Corte Madera shoreline, 1931 to 2016. Dashed line indicates that no end point rate values were calculated. Colors indicate character of rate-calculation zones: green, natural shoreline (CC, Corte Madera Creek; HM, Heerdt marsh; OM, outer Muzzi marsh; TM, Triangle marsh); yellow, diked shoreline (MM, Marta's marsh; NM-N, north Muzzi marsh [north]; NM-S, north Muzzi marsh [south]); gray, armored residential shoreline (MC, Mariner Cove). Widths of color bands are proportional to areas of rate-calculation zones. Note that outer Muzzi marsh shoreline has been a natural shoreline since about 2012.

\section{Acknowledgments}

We would like to thank reviewers Mary McGann and Eric Geist for providing very useful suggestions for improvement of the text. Geoffrey Phelps is thanked for his generous help with matters involving GIS. Thanks to James Zoulas, U.S. Army Corps. of Engineers, for use of his unpublished shoreline-change determinations. Most maps in this report were created using ArcGIS software by Esri.

\section{References Cited}

Anders, F.J., and Byrnes, M.R., 1991, Accuracy of shoreline change rates as determined from maps and aerial photos: Shore and Beach, v. 59, no. 1, p. 17-26.

Atwater, B.F., Conrad, S.G., Dowden, J.N., Hedel, C.W., MacDonald, R.L., and Savage, W., 1979, History, landforms, and vegetation of the estuary's tidal marshes, in Conomos, T.J., Leviton, A.E., and Berson, M., eds., San Francisco Bay, the urbanized estuary-Investigations into the natural history of San Francisco Bay and delta with reference to the influence of man: San Francisco, Calif., American Association for the Advancement of Science, Pacific Division, Annual Meeting, June 12-16, 1977, p. 347-385.

Brah, W.J., 1982, The Muzzi marsh—A case study and analysis of wetland restoration decision-making in San Francisco Bay: College Station, Texas A\&M University, M.S. thesis, $118 \mathrm{p}$.
Callaway, J.C., Borgnis, E.L., Turner, R.E., and Milan, C.S., 2012, Wetland sediment accumulation at Corte Madera marsh and Muzzi marsh: Report prepared for San Francisco Bay Conservation and Development Commission.

Crowell, M., Leatherman, S.P., and Buckley, M.K., 1991, Historical shoreline change-Error analysis and mapping accuracy: Journal of Coastal Research, v. 7, no. 3, p. 839-852.

Faber, P., 1980, Marsh restoration-A case study from California, in Utilization of science in the decision-making process: The Coastal Society, Proceedings of the 6th Annual Conference, San Diego, Calif., Oct. 13-15, 1980, p. 167-177.

Faber, P., Shepperd, A., and Williams, P., 1988, Monitoring a tidal restoration site in San Francisco Bay-The Muzzi marsh, in Proceedings of the 3d Symposium on Coastal and Ocean Management, June 1988, p. 729-734.

Himmelstoss, E.A., 2009, DSAS 4.0 installation and user guide, in Thieler, E.R., Himmelstoss, E.A., Zichichi, J.L., and Ergul, A., 2009, The Digital Shoreline Analysis System (DSAS) version 4.0-An ArcGIS extension for calculating shoreline change: U.S. Geological Survey Open-File Report 2008-1278, 81 p., https://doi.org/10.3133/ofr20081278.

Lacy, J.R., and Hoover, D.J., 2011, Wave exposure of Corte Madera marsh, Marin County, California-A field investigation: U.S. Geological Survey Open-File Report 2011-1183, 28 p., https://doi.org/10.3133/ofr20111183. 


\section{Appendix 1. End Point Rates for Corte Madera Creek (CC) and Heerdt Marsh (HM-1 through HM-7) Rate-Calculation Zones, Corte Madera Shoreline}

The shorelines at Corte Madera Creek and Heerdt marsh (fig. 1-1), Corte Madera, have experienced overall retreat between the years 1931 to 2016, as indicated by the net shoreline movement and end point rate values (figs. 1-2 through 1-9; tables 1-1 through 1-8) measured in this study.

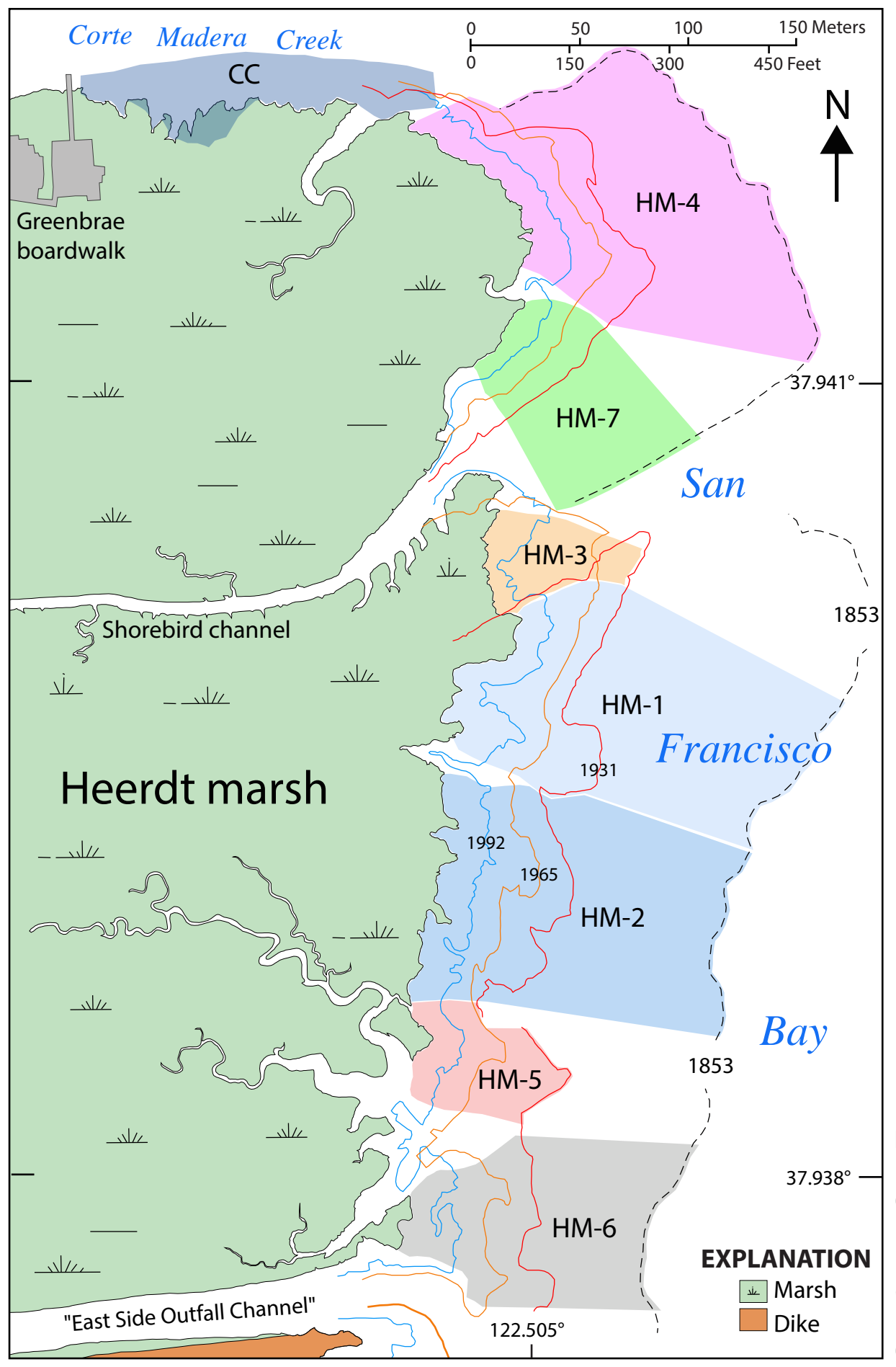

Figure 1-1. Map showing ratecalculation zones at Corte Madera Creek (CC) and Heerdt marsh (HM-1 through HM-7), Corte Madera shoreline. Dashed black line shows approximate location of 1853 shoreline; colored lines show positions of shoreline in 1931 (red), 1965 (orange), and 1992 (blue). 

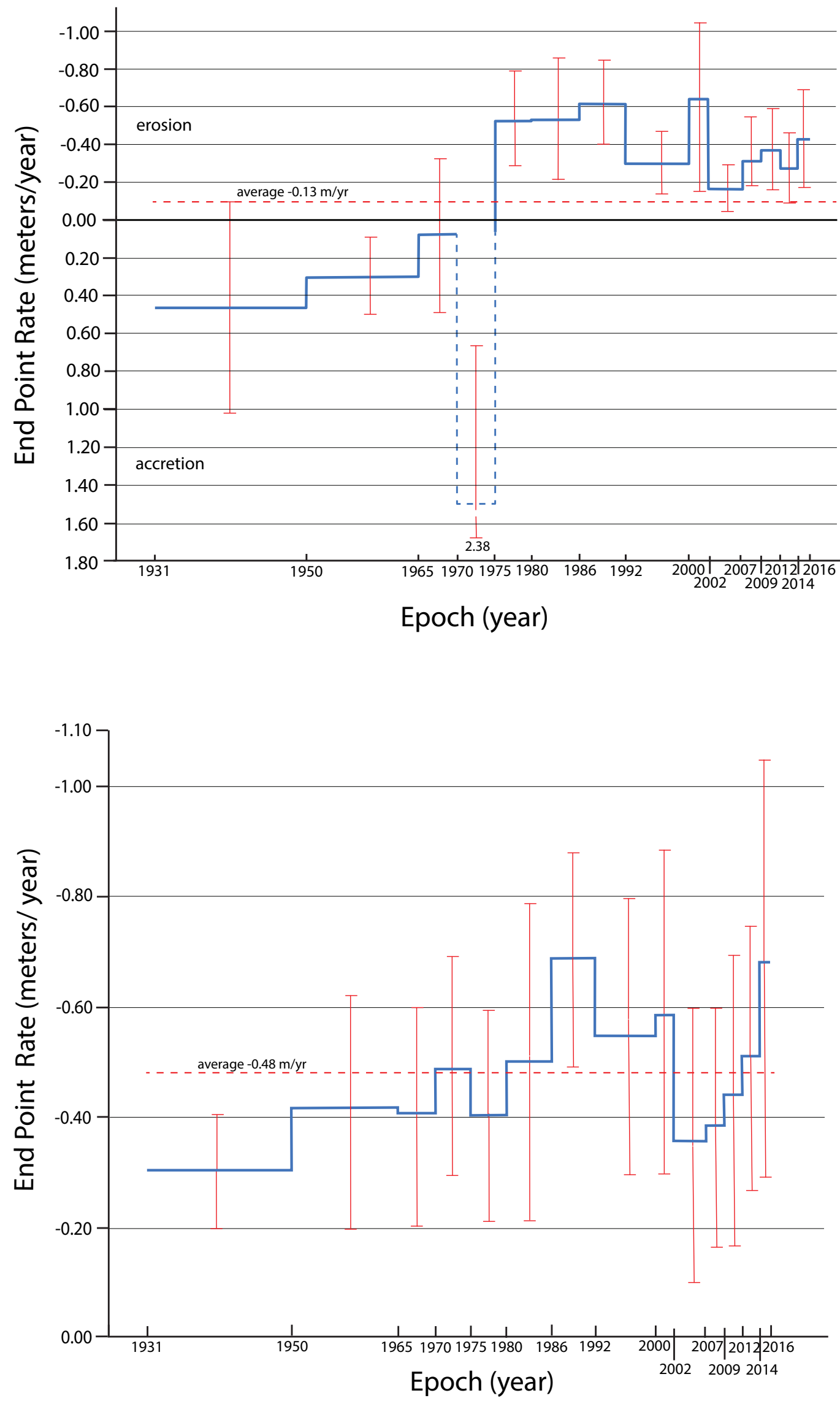

Figure 1-2. Plot showing end point rate values (blue line) for Corte Madera Creek rate-calculation zone $\mathrm{CC}$, Corte Madera shoreline; dashed blue line indicates uncertainty in values for 1970 to 1975 epoch owing to poor identification of shoreline on unvegetated mud flat. Dashed red line shows averaged retreat value of -0.13 $\mathrm{m} / \mathrm{yr}$. Error bars (red lines) are average \pm 1 -sigma variation in rates for each epoch.
Figure 1-3. Plot showing end point rate values (blue line) for Heerdt marsh rate-calculation zone HM-1, Corte Madera shoreline. Dashed red line shows averaged retreat value of $-0.48 \mathrm{~m} / \mathrm{yr}$. Error bars (red lines) are average \pm 1 -sigma variation in rates for each epoch. 


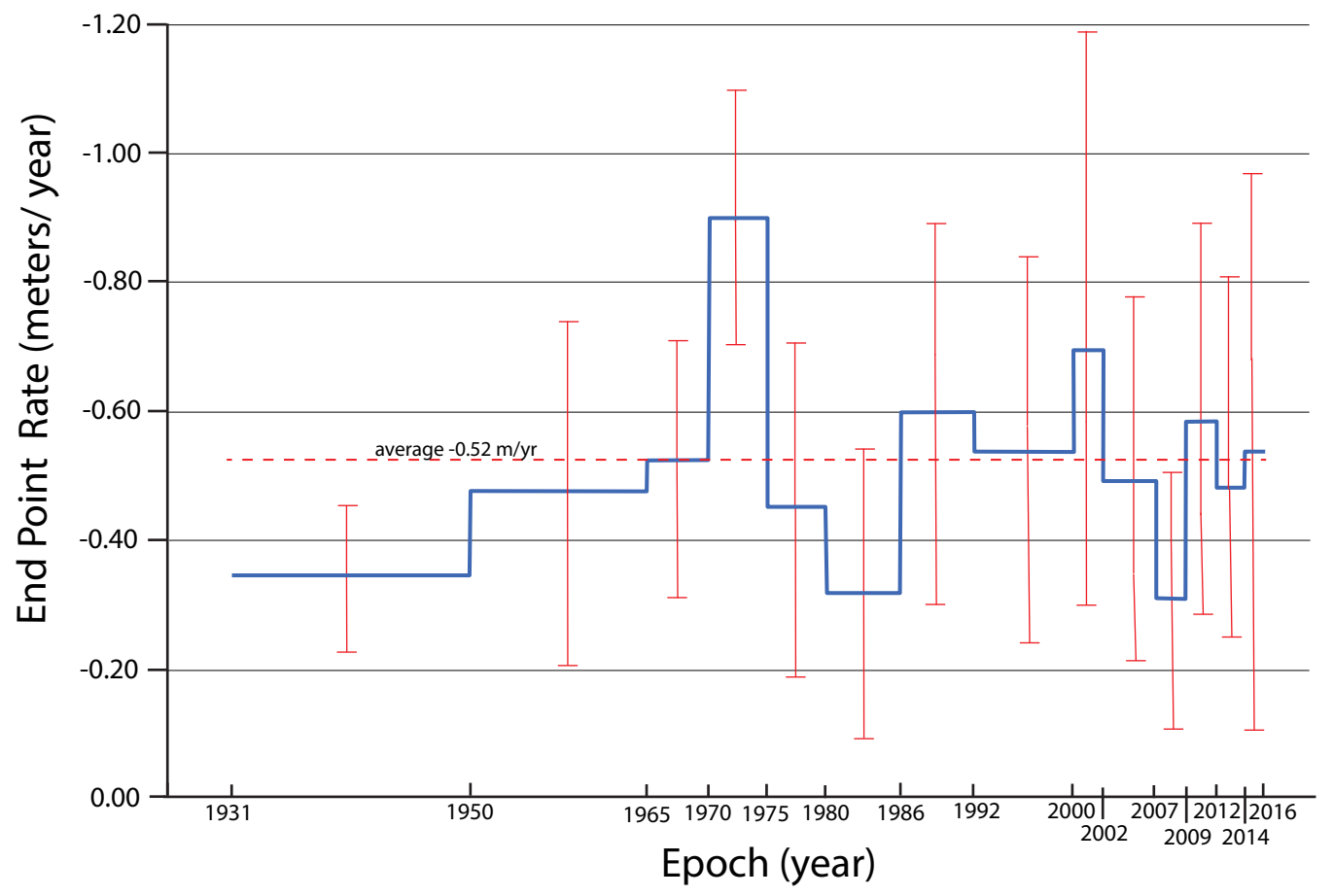

Figure 1-4. Plot showing end point rate values (blue line) for Heerdt marsh rate-calculation zone HM-2, Corte Madera shoreline. Dashed red line shows averaged retreat value of -0.52 $\mathrm{m} / \mathrm{yr}$. Error bars (red lines) are average \pm 1 -sigma variation in rates for each epoch.

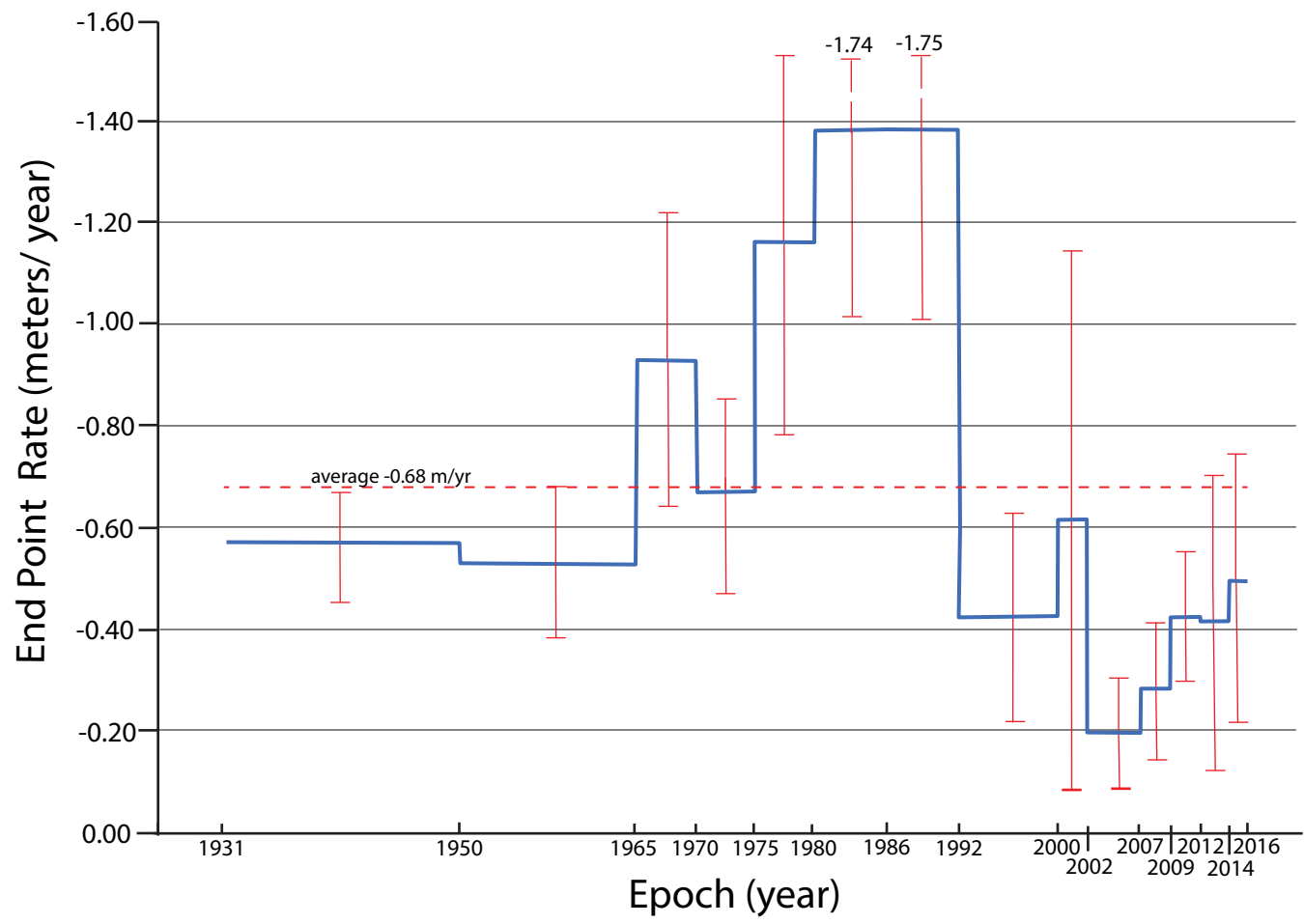

Figure 1-5. Plot showing end point rate values (blue line) for Heerdt marsh rate-calculation zone HM-3, Corte Madera shoreline. Dashed red line shows averaged retreat value of -0.68 $\mathrm{m} / \mathrm{yr}$. Error bars (red lines) are average \pm 1 -sigma variation in rates for each epoch. 

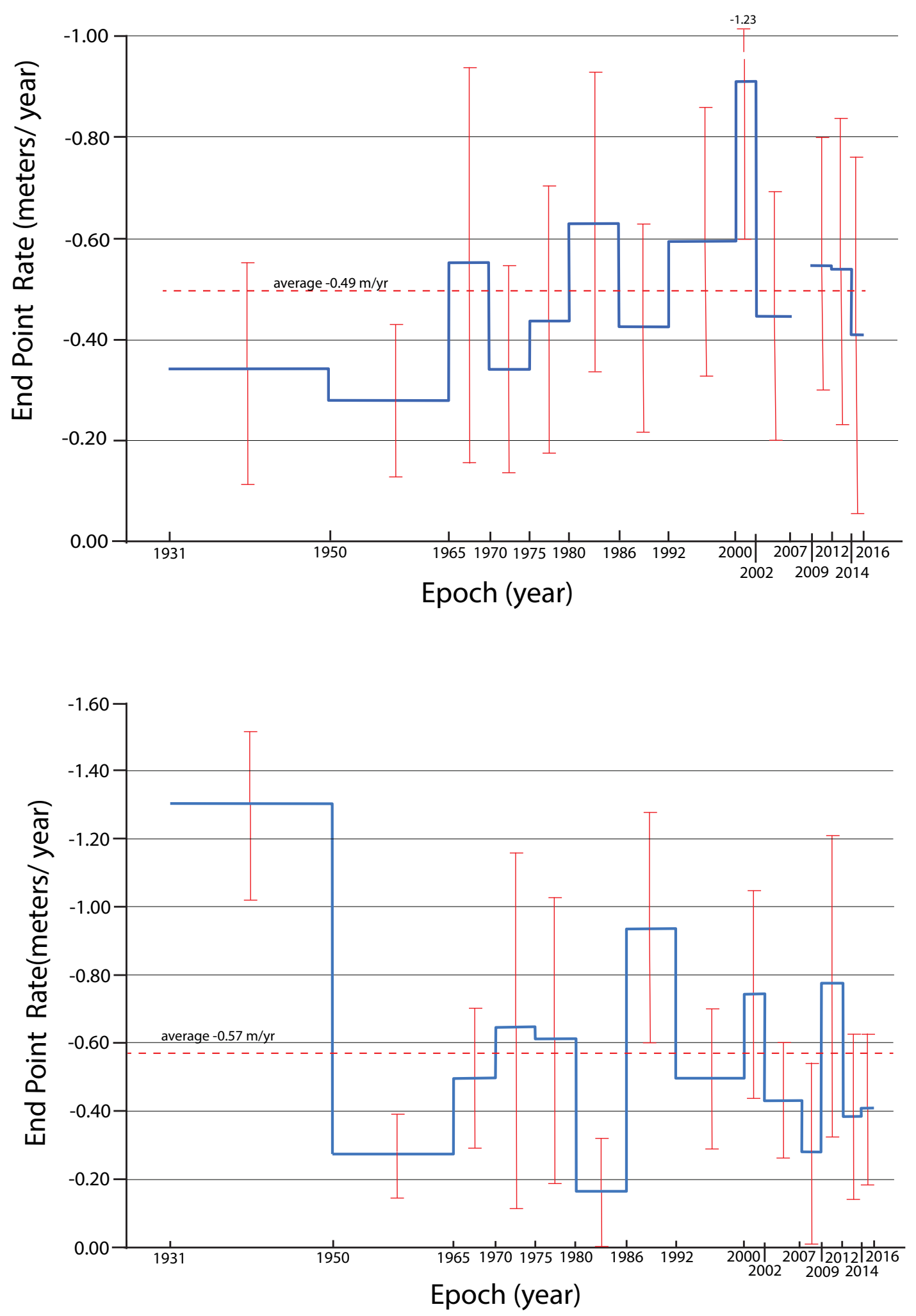

Figure 1-6. Plot showing end point rate values (blue line) for Heerdt marsh rate-calculation zone HM-4, Corte Madera shoreline. Dashed red line shows averaged retreat value of -0.49 $\mathrm{m} / \mathrm{yr}$. Error bars (red lines) are average \pm 1 -sigma variation in rates for each epoch.
Figure 1-7. Plot showing end point rate values (blue line) for Heerdt marsh rate-calculation zone HM-5, Corte Madera shoreline. Dashed red line shows averaged retreat value of -0.57 $\mathrm{m} / \mathrm{yr}$. Error bars (red lines) are average \pm 1 -sigma variation in rates for each epoch. 

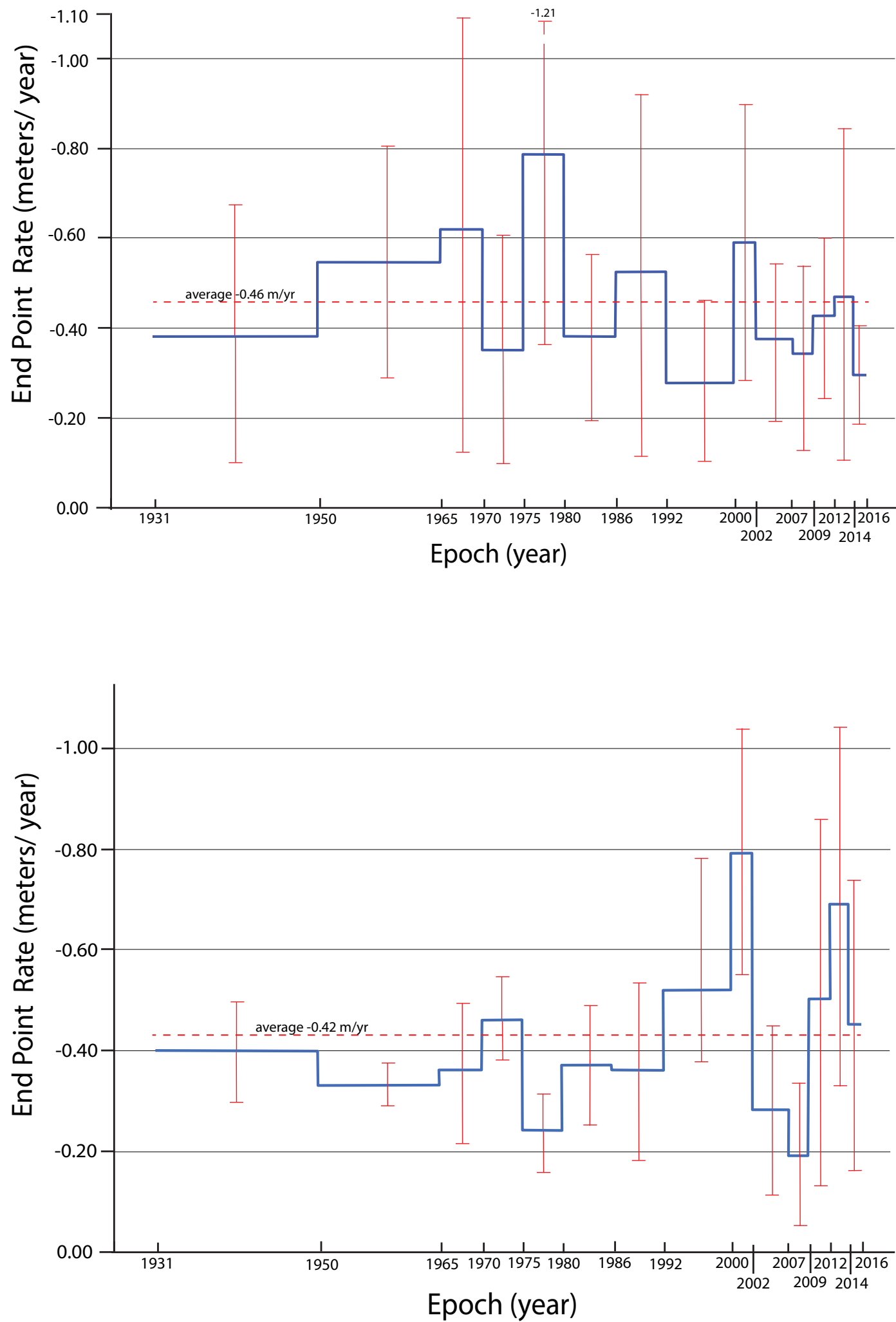

Figure 1-8. Plot showing end point rate values (blue line) for Heerdt marsh rate-calculation zone HM-6, Corte Madera shoreline. Dashed red line shows averaged retreat value of -0.46 $\mathrm{m} / \mathrm{yr}$. Error bars (red lines) are average \pm 1 -sigma variation in rates for each epoch.

Figure 1-9. Plot showing end point rate values (blue line) for Heerdt marsh rate-calculation zone HM-7, Corte Madera shoreline. Dashed red line shows averaged retreat value of -0.43 $\mathrm{m} / \mathrm{yr}$. Error bars (red lines) are average \pm 1 -sigma variation in rates for each epoch. 
Table 1-1. Measured net shoreline movement and end point rate values determined for Corte Madera Creek rate-calculation zone CC, Corte Madera shoreline.

[Cumulative shoreline movement values determined from average net shoreline movement values starting in 1931. Abbreviations: EPR, end point rate value; $\mathrm{m}$, meter(s); NSM, net shoreline movement value; yr, year(s). Negative values indicate erosion; positive values indicate accretion]

\begin{tabular}{ccccccccccc}
\hline Epoch & $\begin{array}{c}\text { Epoch } \\
\text { duration } \\
\text { (yr) }\end{array}$ & $\begin{array}{c}\text { Baseline } \\
\text { length } \\
\text { (m) }\end{array}$ & $\begin{array}{c}\text { Transect } \\
\text { spacing } \\
\text { (m) }\end{array}$ & $\begin{array}{c}\text { Transects } \\
\text { cast }\end{array}$ & $\begin{array}{c}\text { Transects } \\
\text { used }\end{array}$ & $\begin{array}{c}\text { NSM range } \\
\text { (m) }\end{array}$ & $\begin{array}{c}\text { NSM } \\
\text { average } \\
\text { (m) }\end{array}$ & $\begin{array}{c}\text { EPR } \\
\text { average } \\
\text { (m/ } \mathbf{y r})\end{array}$ & $\begin{array}{c}\text { EPR standard } \\
\text { deviation } \\
\text { (m/ } \mathbf{r})\end{array}$ & $\begin{array}{c}\text { Cumulative } \\
\text { shoreline } \\
\text { movement (m) }\end{array}$ \\
\hline $2016-2014$ & 1.56 & 216 & 6 & 37 & 30 & -0.16 to -1.8 & -0.67 & -0.43 & 0.25 & -17.4 \\
$2014-2012$ & 2.3 & 216 & 6 & 37 & 29 & -0.03 to -2 & -0.63 & -0.27 & 0.18 & -16.8 \\
$2012-2009$ & 2.53 & 228 & 6 & 39 & 35 & -0.16 to -2 & -0.95 & -0.38 & 0.20 & -16.1 \\
$2009-2007$ & 2.4 & 246 & 6 & 42 & 22 & -0.1 to -2 & -0.76 & -0.32 & 0.23 & -15.2 \\
$2007-2002$ & 4.42 & 264 & 6 & 45 & 33 & -0.1 to -2.6 & -0.74 & -0.17 & 0.13 & -14.4 \\
$2002-2000$ & 2.51 & 276 & 6 & 47 & 26 & -0.5 to -6.4 & -1.63 & -0.65 & 0.50 & -13.7 \\
$2000-1992$ & 8.17 & 186 & 6 & 32 & 27 & -0.23 to -5.6 & -2.46 & -0.30 & 0.17 & -12.0 \\
$1992-1986$ & 6.02 & 192 & 6 & 33 & 25 & -0.9 to -5.9 & -3.74 & -0.62 & 0.22 & -9.6 \\
$1986-1980$ & 6.11 & 174 & 6 & 30 & 21 & -0.6 to -7.7 & -3.28 & -0.54 & 0.32 & -5.9 \\
$1980-1975$ & 4.87 & 132 & 6 & 23 & 19 & -0.3 to -4.32 & -2.57 & -0.53 & 0.25 & -2.6 \\
$1975-1970$ & 4.83 & 132 & 6 & 23 & 22 & -0.3 to 13.6 & 7.38 & 1.52 & 0.86 & 20.8 \\
$1970-1965$ & 5.05 & 138 & 6 & 24 & 24 & -2.61 to 3.4 & 0.36 & 0.07 & 0.4 & 13.5 \\
$1965-1950$ & 14.6 & 138 & 6 & 24 & 24 & -2.3 to 11 & 4.4 & 0.3 & 0.22 & 13.1 \\
$1950-1931$ & 19.5 & 150 & 10 & 16 & 16 & -2.8 to 27 & 8.7 & 0.46 & 0.56 & 8.7 \\
\hline
\end{tabular}

Table 1-2. Measured net shoreline movement and end point rate values determined for Heerdt marsh rate-calculation zone HM-1, Corte Madera shoreline.

[Abbreviations: EPR, end point rate value; $\mathrm{m}$, meter(s); NSM, net shoreline movement value; yr, year(s). Negative values indicate erosion; positive values indicate accretion. Cumulative shoreline movement values determined from average net shoreline movement values starting in 1931]

\begin{tabular}{cccccccccccc}
\hline Epoch & $\begin{array}{c}\text { Epoch } \\
\text { duration } \\
\text { (yr) }\end{array}$ & $\begin{array}{c}\text { Baseline } \\
\text { length } \\
\text { (m) }\end{array}$ & $\begin{array}{c}\text { Transect } \\
\text { spacing } \\
\text { (m) }\end{array}$ & $\begin{array}{c}\text { Transects } \\
\text { cast }\end{array}$ & $\begin{array}{c}\text { Transects } \\
\text { used }\end{array}$ & $\begin{array}{c}\text { NSM range } \\
\text { (m) }\end{array}$ & $\begin{array}{c}\text { NSM } \\
\text { average } \\
\text { (m) }\end{array}$ & $\begin{array}{c}\text { EPR } \\
\text { average } \\
\text { (m/yr) }\end{array}$ & $\begin{array}{c}\text { EPR standard } \\
\text { deviation } \\
\text { (m/yr) }\end{array}$ & $\begin{array}{c}\text { Cumulative } \\
\text { shoreline } \\
\text { movement }\end{array}$ \\
\hline $2016-2014$ & 1.56 & 110 & 5 & 23 & 21 & -0.02 to -2.11 & -1.06 & -0.68 & 0.38 & -37.7 \\
$2014-2012$ & 2.3 & 110 & 5 & 23 & 19 & -0.3 to -2.18 & -1.17 & -0.51 & 0.24 & -36.6 \\
$2012-2009$ & 2.53 & 120 & 5 & 25 & 23 & -0.3 to -2.93 & -1.12 & -0.44 & 0.27 & -35.5 \\
$2009-2007$ & 2.4 & 125 & 5 & 26 & 20 & -0.2 to -2.0 & -0.93 & -0.39 & 0.22 & -34.4 \\
$2007-2002$ & 4.42 & 130 & 5 & 27 & 22 & -0.4 to -4.4 & -1.57 & -0.36 & 0.25 & -33.4 \\
$2002-2000$ & 2.51 & 130 & 5 & 27 & 23 & -0.3 to -3.6 & -1.47 & -0.58 & 0.29 & -31.9 \\
$2000-1992$ & 8.17 & 145 & 5 & 30 & 23 & -1.0 to -10.9 & -4.48 & -0.55 & 0.24 & -30.4 \\
$1992-1986$ & 6.02 & 130 & 5 & 27 & 21 & -2.4 to -6.9 & -4.45 & -0.69 & 0.19 & -25.9 \\
$1986-1980$ & 6.11 & 120 & 5 & 25 & 22 & -0.1 to -7.2 & -3.06 & -0.50 & 0.28 & -21.5 \\
$1980-1975$ & 4.87 & 115 & 5 & 24 & 18 & -0.31 to -3.6 & -1.97 & -0.40 & 0.18 & -18.4 \\
$1975-1970$ & 4.83 & 105 & 5 & 22 & 19 & -1 to -4.7 & -2.37 & -0.49 & 0.20 & -16.4 \\
$1970-1965$ & 5.05 & 95 & 5 & 20 & 18 & -1 to -3.7 & -2.05 & -0.41 & 0.20 & -14.1 \\
$1965-1950$ & 14.6 & 95 & 5 & 20 & 20 & -3.4 to -15.6 & -6.20 & -0.42 & 0.22 & -12.0 \\
$1950-1931$ & 19.5 & 105 & 5 & 22 & 22 & -1.9 to -10.5 & -5.82 & -0.31 & 0.11 & -5.8 \\
$1931-1853$ & 77.9 & 110 & 10 & 12 & 9 & -70 to -109 & -95 & -1.2 & 0.22 & -95.0 \\
\hline
\end{tabular}


Table 1-3. Measured net shoreline movement and end point rate values determined for Heerdt marsh rate-calculation zone HM-2, Corte Madera shoreline.

[Abbreviations: EPR, end point rate value; $\mathrm{m}$, meter(s); NSM, net shoreline movement value; yr, year(s). Negative values indicate erosion; positive values indicate accretion. Cumulative shoreline movement values determined from average net shoreline movement values starting in 1931]

\begin{tabular}{|c|c|c|c|c|c|c|c|c|c|c|}
\hline Epoch & $\begin{array}{c}\text { Epoch } \\
\text { duration } \\
\text { (yr) }\end{array}$ & $\begin{array}{l}\text { Baseline } \\
\text { length } \\
(\mathrm{m})\end{array}$ & $\begin{array}{c}\text { Transect } \\
\text { spacing } \\
(\mathrm{m})\end{array}$ & $\begin{array}{c}\text { Transects } \\
\text { cast }\end{array}$ & $\begin{array}{l}\text { Tran- } \\
\text { sects } \\
\text { used }\end{array}$ & $\begin{array}{l}\text { NSM range } \\
(\mathrm{m})\end{array}$ & $\begin{array}{c}\text { NSM } \\
\text { average } \\
(\mathrm{m})\end{array}$ & $\begin{array}{c}\text { EPR } \\
\text { average } \\
\text { (m/yr) }\end{array}$ & $\begin{array}{c}\text { EPR standard } \\
\text { deviation } \\
\text { (m/yr) }\end{array}$ & $\begin{array}{c}\text { Cumulative } \\
\text { shoreline } \\
\text { movement (m) }\end{array}$ \\
\hline 2016-2014 & 1.56 & 160 & 5 & 33 & 29 & -0.02 to -2.9 & -0.84 & -0.54 & 0.43 & -41.0 \\
\hline 2014-2012 & 2.3 & 165 & 5 & 34 & 29 & -0.1 to -3.2 & -1.10 & -0.48 & 0.33 & -40.1 \\
\hline 2012-2009 & 2.53 & 170 & 5 & 35 & 32 & -0.24 to -3 & -1.49 & -0.59 & 0.30 & -39.0 \\
\hline 2009-2007 & 2.4 & 170 & 5 & 35 & 23 & -0.02 to -2.1 & -0.74 & -0.31 & 0.20 & -37.5 \\
\hline 2007-2002 & 4.42 & 170 & 5 & 35 & 29 & -0.16 to -5 & -2.18 & -0.49 & 0.27 & -36.8 \\
\hline $2002-2000$ & 2.51 & 170 & 5 & 35 & 31 & -0.01 to -5.4 & -1.75 & -0.70 & 0.40 & -34.6 \\
\hline 2000-1992 & 8.17 & 160 & 5 & 33 & 27 & -0.32 to -11.6 & -4.39 & -0.54 & 0.30 & -32.9 \\
\hline 1992-1986 & 6.02 & 145 & 5 & 30 & 18 & -0.74 to -6.7 & -3.60 & -0.60 & 0.29 & -28.5 \\
\hline 1986-1980 & 6.11 & 115 & 5 & 24 & 18 & -0.3 to -4.9 & -1.95 & -0.32 & 0.23 & -24.9 \\
\hline 1980-1975 & 4.87 & 115 & 5 & 24 & 19 & -0.47 to -4.8 & -2.20 & -0.45 & 0.26 & -22.9 \\
\hline 1975-1970 & 4.83 & 115 & 5 & 24 & 19 & -0.16 to -16.1 & -4.37 & -0.90 & 1.04 & -20.8 \\
\hline 1970-1965 & 5.05 & 140 & 5 & 29 & 27 & -0.54 to -4.5 & -2.63 & -0.52 & 0.20 & -16.4 \\
\hline 1965-1950 & 14.6 & 145 & 5 & 30 & 22 & -0.7 to -16 & -7.14 & -0.48 & 0.26 & -13.8 \\
\hline 1950-1931 & 19.5 & 135 & 5 & 28 & 19 & -1.6 to -11.4 & -6.61 & -0.35 & 0.11 & -6.6 \\
\hline $1931-1853$ & 77.9 & 140 & 10 & 15 & 12 & -64 to -92 & -80 & -1.0 & 0.12 & -80 \\
\hline
\end{tabular}

Table 1-4. Measured net shoreline movement and end point rate values determined for Heerdt marsh rate-calculation zone HM-3, Corte Madera shoreline.

[Abbreviations: EPR, end point rate value; $\mathrm{m}$, meter(s); NSM, net shoreline movement value; yr, year(s). Negative values indicate erosion; positive values indicate accretion. Cumulative shoreline movement values determined from average net shoreline movement values starting in 1931]

\begin{tabular}{|c|c|c|c|c|c|c|c|c|c|c|}
\hline Epoch & $\begin{array}{c}\text { Epoch } \\
\text { duration } \\
\text { (yr) }\end{array}$ & $\begin{array}{l}\text { Baseline } \\
\text { length } \\
\text { (m) }\end{array}$ & $\begin{array}{l}\text { Transect } \\
\text { spacing } \\
\text { (m) }\end{array}$ & $\begin{array}{c}\text { Transects } \\
\text { cast }\end{array}$ & $\begin{array}{c}\text { Transects } \\
\text { used }\end{array}$ & $\begin{array}{c}\text { NSM range } \\
(\mathrm{m})\end{array}$ & $\begin{array}{c}\text { NSM } \\
\text { average } \\
\text { (m) }\end{array}$ & $\begin{array}{c}\text { EPR } \\
\text { average } \\
\text { (m/yr) }\end{array}$ & $\begin{array}{c}\text { EPR standard } \\
\text { deviation } \\
\text { (m/yr) }\end{array}$ & $\begin{array}{c}\text { Cumulative } \\
\text { shoreline } \\
\text { movement (m) }\end{array}$ \\
\hline 2016-2014 & 1.56 & 55 & 5 & 12 & 12 & -0.25 to -2 & -0.77 & -0.49 & 0.27 & -58.4 \\
\hline 2014-2012 & 2.3 & 55 & 5 & 12 & 12 & -0.3 to -2.5 & -0.95 & -0.42 & 0.29 & -57.6 \\
\hline 2012-2009 & 2.53 & 60 & 5 & 13 & 12 & -0.54 to -1.5 & -1.07 & -0.42 & 0.13 & -56.6 \\
\hline 2009-2007 & 2.4 & 55 & 5 & 12 & 12 & -0.1 to -1.1 & -0.68 & -0.28 & 0.13 & -55.6 \\
\hline 2007-2002 & 4.42 & 50 & 5 & 11 & 8 & -0.22 to -1.6 & -0.86 & -0.19 & 0.10 & -54.9 \\
\hline $2002-2000$ & 2.51 & 50 & 5 & 11 & 9 & -0.18 to -3.6 & -1.54 & -0.61 & 0.54 & -54.0 \\
\hline 2000-1992 & 8.17 & 55 & 5 & 12 & 9 & -1.8 to -7.3 & -3.46 & -0.42 & 0.21 & -52.5 \\
\hline 1992-1986 & 6.02 & 55 & 5 & 12 & 7 & -6.2 to -12.4 & -8.32 & -1.38 & 0.37 & -49.0 \\
\hline 1986-1980 & 6.11 & 36 & 4 & 10 & 8 & -6.5 to -11.9 & -8.42 & -1.38 & 0.36 & -40.7 \\
\hline 1980-1975 & 4.87 & 32 & 4 & 9 & 8 & -3.8 to -9.2 & -5.66 & -1.16 & 0.38 & -32.3 \\
\hline 1975-1970 & 4.83 & 24 & 4 & 7 & 6 & -1.4 to -4.1 & -3.25 & -0.67 & 0.20 & -26.6 \\
\hline 1970-1965 & 5.05 & 24 & 4 & 7 & 7 & -2.2 to -6.4 & -4.66 & -0.93 & 0.29 & -23.4 \\
\hline 1965-1950 & 14.6 & 20 & 4 & 6 & 6 & -5 to -10.3 & -7.90 & -0.53 & 0.15 & -18.7 \\
\hline 1950-1931 & 19.5 & 16 & 4 & 5 & 5 & -8.4 to -12.7 & -10.83 & -0.57 & 0.09 & -10.8 \\
\hline
\end{tabular}


Table 1-5. Measured net shoreline movement and end point rate values determined for Heerdt marsh rate-calculation zone HM-4, Corte Madera shoreline.

[Abbreviations: EPR, end point rate value; $\mathrm{m}$, meter(s); NSM, net shoreline movement value; yr, year(s); --, anomalous value omitted. Negative values indicate erosion; positive values indicate accretion. Cumulative shoreline movement values determined from average net shoreline movement values starting in 1931]

\begin{tabular}{|c|c|c|c|c|c|c|c|c|c|c|}
\hline Epoch & $\begin{array}{c}\text { Epoch } \\
\text { duration } \\
\text { (yr) }\end{array}$ & $\begin{array}{l}\text { Baseline } \\
\text { length } \\
\text { (m) }\end{array}$ & $\begin{array}{l}\text { Transect } \\
\text { spacing } \\
\text { (m) }\end{array}$ & $\begin{array}{l}\text { Transects } \\
\text { cast }\end{array}$ & $\begin{array}{c}\text { Transects } \\
\text { used }\end{array}$ & $\begin{array}{l}\text { NSM range } \\
(\mathrm{m})\end{array}$ & $\begin{array}{l}\text { NSM } \\
\text { average } \\
\text { (m) }\end{array}$ & $\begin{array}{c}\text { EPR } \\
\text { average } \\
(\mathrm{m} / \mathrm{yr})\end{array}$ & $\begin{array}{l}\text { EPR standard } \\
\text { deviation } \\
(\mathrm{m} / \mathrm{yr})\end{array}$ & $\begin{array}{l}\text { Cumulative } \\
\text { shoreline } \\
\text { movement (m) }\end{array}$ \\
\hline 2016-2014 & 1.56 & 130 & 5 & 27 & 20 & -0.1 to -2.04 & -0.64 & -0.41 & 0.36 & -36.1 \\
\hline 2014-2012 & 2.3 & 135 & 5 & 28 & 25 & -0.1 to -2.73 & -1.24 & -0.54 & 0.31 & -35.5 \\
\hline 2012-2009 & 2.53 & 140 & 5 & 29 & 25 & -0.02 to -2.8 & -1.38 & -0.55 & 0.25 & -34.2 \\
\hline $2009-2007^{[1]}$ & 2.4 & 135 & 5 & 28 & -- & -- & -- & -- & -- & -- \\
\hline 2007-2002 & 4.42 & 145 & 5 & 30 & 26 & -0.2 to -4.1 & -1.97 & -0.44 & 0.24 & -32.8 \\
\hline $2002-2000$ & 2.51 & 140 & 5 & 29 & 25 & -0.9 to -3.8 & -2.29 & -0.91 & 0.31 & -30.9 \\
\hline 2000-1992 & 8.17 & 130 & 5 & 27 & 24 & -1.8 to -9.8 & -4.86 & -0.60 & 0.26 & -28.6 \\
\hline 1992-1986 & 6.02 & 125 & 5 & 26 & 20 & -0.14 to -5.2 & -2.56 & -0.42 & 0.21 & -23.7 \\
\hline 1986-1980 & 6.11 & 130 & 5 & 27 & 24 & -1.7 to -8.2 & -3.85 & -0.63 & 0.29 & -21.1 \\
\hline $1980-1975$ & 4.87 & 135 & 5 & 28 & 23 & -0.12 to -5.4 & -2.13 & -0.44 & 0.27 & -17.3 \\
\hline 1975-1970 & 4.83 & 140 & 5 & 29 & 16 & -0.2 to -3.9 & -1.66 & -0.34 & 0.21 & -15.2 \\
\hline $1970-1965$ & 5.05 & 150 & 5 & 31 & 28 & -0.7 to -9.6 & -2.78 & -0.55 & 0.39 & -13.5 \\
\hline $1965-1950$ & 14.6 & 155 & 5 & 32 & 22 & -0.12 to -7.5 & -4.17 & -0.28 & 0.15 & -10.7 \\
\hline $1950-1931$ & 19.5 & 175 & 5 & 36 & 28 & -0.18 to -13.5 & -6.56 & -0.34 & 0.22 & -6.6 \\
\hline $1931-1853$ & 77.9 & 195 & 15 & 14 & 14 & -69 to 27 & -38 & -0.44 & 0.44 & -38 \\
\hline
\end{tabular}

${ }^{1}$ Anomalous values for 2009-2007 epoch have been omitted because they almost entirely indicate accretion in area where, and during time when, accretion was unlikely, possibly suggesting that irregularities in image registration occurred.

Table 1-6. Measured net shoreline movement and end point rate values determined for Heerdt marsh rate-calculation zone HM-5, Corte Madera shoreline.

[Cumulative shoreline movement values determined from average net shoreline movement values starting in 1931. Abbreviations: EPR, end point rate value; $\mathrm{m}$, meter(s); NSM, net shoreline movement value; yr, year(s). Negative values indicate erosion; positive values indicate accretion]

\begin{tabular}{|c|c|c|c|c|c|c|c|c|c|c|}
\hline Epoch & $\begin{array}{l}\text { Epoch } \\
\text { duration } \\
\text { (yr) }\end{array}$ & $\begin{array}{l}\text { Baseline } \\
\text { length }(\mathrm{m})\end{array}$ & $\begin{array}{c}\text { Transect } \\
\text { spacing (m) }\end{array}$ & $\begin{array}{c}\text { Transects } \\
\text { cast }\end{array}$ & $\begin{array}{c}\text { Transects } \\
\text { used }\end{array}$ & NSM range (m) & $\begin{array}{c}\text { NSM } \\
\text { average } \\
(\mathrm{m})\end{array}$ & $\begin{array}{c}\text { EPR } \\
\text { average } \\
\text { (m/yr) }\end{array}$ & $\begin{array}{l}\text { EPR standard } \\
\text { deviation } \\
\text { (m/yr) }\end{array}$ & $\begin{array}{l}\text { Cumulative } \\
\text { shoreline } \\
\text { movement (m) }\end{array}$ \\
\hline 2016-2014 & 1.56 & 30 & 3 & 11 & 11 & -0.1 to -1.14 & -0.64 & -0.41 & 0.23 & -56.2 \\
\hline 2014-2012 & 2.3 & 33 & 3 & 12 & 10 & -0.03 to -1.6 & -0.88 & -0.38 & 0.24 & -55.56 \\
\hline 2012-2009 & 2.53 & 48 & 3 & 17 & 17 & -0.52 to -3.9 & -1.95 & -0.78 & 0.44 & -54.68 \\
\hline 2009-2007 & 2.4 & 52 & 4 & 14 & 9 & -0.05 to -2.13 & -0.67 & -0.28 & 0.27 & -52.73 \\
\hline $2007-2002$ & 4.42 & 60 & 4 & 16 & 16 & -0.66 to -3.46 & -1.9 & -0.43 & 0.17 & -52.06 \\
\hline $2002-2000$ & 2.51 & 64 & 4 & 17 & 17 & -0.9 to -3.84 & -1.87 & -0.74 & 0.31 & -50.16 \\
\hline 2000-1992 & 8.17 & 68 & 4 & 18 & 18 & -0.5 to -7.6 & -4.05 & -0.5 & 0.22 & -48.29 \\
\hline 1992-1986 & 6.02 & 55 & 5 & 12 & 11 & -1.65 to -9.3 & -5.63 & -0.93 & 0.34 & -44.24 \\
\hline 1986-1980 & 6.11 & 55 & 5 & 12 & 8 & -0.2 to -3.2 & -1 & -0.16 & 0.16 & -38.61 \\
\hline 1980-1975 & 4.87 & 55 & 5 & 12 & 12 & -0.2 to -6.8 & -2.98 & -0.61 & 0.42 & -37.61 \\
\hline
\end{tabular}


Table 1-6. Measured net shoreline movement and end point rate values determined for Heerdt marsh rate-calculation zone HM-5, Corte Madera shoreline.-Continued

\begin{tabular}{|c|c|c|c|c|c|c|c|c|c|c|}
\hline Epoch & $\begin{array}{c}\text { Epoch } \\
\text { duration } \\
\text { (yr) }\end{array}$ & $\begin{array}{l}\text { Baseline } \\
\text { length }(\mathrm{m})\end{array}$ & $\begin{array}{c}\text { Transect } \\
\text { spacing (m) }\end{array}$ & $\begin{array}{c}\text { Transects } \\
\text { cast }\end{array}$ & $\begin{array}{c}\text { Transects } \\
\text { used }\end{array}$ & NSM range (m) & $\begin{array}{c}\text { NSM } \\
\text { average } \\
(\mathrm{m})\end{array}$ & $\begin{array}{c}\text { EPR } \\
\text { average } \\
\text { (m/yr) }\end{array}$ & $\begin{array}{l}\text { EPR standard } \\
\text { deviation } \\
\text { (m/yr) }\end{array}$ & $\begin{array}{c}\text { Cumulative } \\
\text { shoreline } \\
\text { movement (m) }\end{array}$ \\
\hline $1975-1970$ & 4.83 & 50 & 5 & 11 & 5 & -0.44 to -7.23 & -3.13 & -0.65 & 0.52 & -34.63 \\
\hline $1970-1965$ & 5.05 & 65 & 5 & 14 & 14 & -1.3 to -4.8 & -2.5 & -0.5 & 0.21 & -31.5 \\
\hline $1965-1950$ & 14.6 & 45 & 5 & 10 & 6 & -0.43 to -5.5 & -4.1 & -0.27 & 0.12 & -29 \\
\hline $1950-1931^{[1]}$ & 19.5 & 40 & 5 & 9 & 8 & -19.6 to -35.8 & -24.9 & -1.3 & 0.28 & -24.9 \\
\hline $1931-1853$ & 77.9 & 45 & 5 & 10 & 6 & -64 to -73 & -69 & -0.9 & 0.04 & -69 \\
\hline
\end{tabular}

${ }^{1}$ Note that anomalously high NSM and EPR values for 1950-1931 epoch might be due to erosion of possible low-elevation projection of land (or part of an island), which may have complicated identification of shoreline; note also that, owing to its uncertainty, EPR value for zone HM- 5 was omitted from EPRaverage calculation for 1950-1931 epoch (see fig. 13).

Table 1-7. Measured net shoreline movement and end point rate values determined for Heerdt marsh rate-calculation zone HM-6, Corte Madera shoreline.

[Cumulative shoreline movement values determined from average net shoreline movement values starting in 1931. Abbreviations: EPR, end point rate value; $\mathrm{m}$, meter(s); NSM, net shoreline movement value; yr, year(s). Negative values indicate erosion; positive values indicate accretion]

\begin{tabular}{ccccccccccc}
\hline Epoch & $\begin{array}{c}\text { Epoch } \\
\text { duration } \\
\text { (yr) }\end{array}$ & $\begin{array}{c}\text { Baseline } \\
\text { length }(\mathbf{m})\end{array}$ & $\begin{array}{c}\text { Transect } \\
\text { spacing }(\mathbf{m})\end{array}$ & $\begin{array}{c}\text { Transects } \\
\text { cast }\end{array}$ & $\begin{array}{c}\text { Transects } \\
\text { used }\end{array}$ & NSM range (m) & $\begin{array}{c}\text { NSM } \\
\text { average } \\
\text { (m) }\end{array}$ & $\begin{array}{c}\text { EPR } \\
\text { average } \\
\text { (m/yr) }\end{array}$ & $\begin{array}{c}\text { EPR standard } \\
\text { deviation } \\
\text { (m/yr) }\end{array}$ & $\begin{array}{c}\text { Cumulative } \\
\text { shoreline } \\
\text { movement (m) }\end{array}$ \\
\hline $2016-2014$ & 1.56 & 30 & 3 & 11 & 11 & -0.3 to -0.9 & -0.46 & -0.3 & 0.12 & -38.6 \\
$2014-2012$ & 2.3 & 30 & 3 & 11 & 10 & -0.13 to -2.84 & -1.08 & -0.47 & 0.38 & -38.1 \\
$2012-2009$ & 2.53 & 51 & 3 & 18 & 17 & -0.34 to -1.7 & -1.1 & -0.43 & 0.17 & -37.0 \\
$2009-2007$ & 2.4 & 55 & 5 & 12 & 8 & -0.1 to -1.8 & -0.82 & -0.34 & 0.21 & -35.9 \\
$2007-2002$ & 4.42 & 95 & 5 & 20 & 14 & -0.33 to -3 & -1.67 & -0.38 & 0.18 & -35.1 \\
$2002-2000$ & 2.51 & 90 & 5 & 19 & 17 & -0.32 to -3.2 & -1.49 & -0.59 & 0.33 & -33.5 \\
$2000-1992$ & 8.17 & 115 & 5 & 24 & 17 & -0.5 to -4.6 & -2.27 & -0.28 & 0.18 & -32.0 \\
$1992-1986$ & 6.02 & 96 & 4 & 25 & 14 & -0.5 to -9.4 & -3.2 & -0.53 & 0.4 & -29.7 \\
$1986-1980$ & 6.11 & 76 & 4 & 20 & 17 & -0.7 to -4.5 & -2.34 & -0.38 & 0.19 & -26.5 \\
$1980-1975$ & 4.87 & 80 & 4 & 21 & 19 & -0.1 to -7.1 & -3.84 & -0.79 & 0.42 & -24.2 \\
$1975-1970$ & 4.83 & 80 & 4 & 21 & 17 & -0.1 to -4 & -1.7 & -0.35 & 0.26 & -20.3 \\
$1970-1965$ & 5.05 & 80 & 4 & 21 & 16 & -1.3 to -11.7 & -3.11 & -0.62 & 0.49 & -18.6 \\
$1965-1950$ & 14.6 & 100 & 10 & 11 & 9 & -3.3 to -13.4 & -8.2 & -0.55 & 0.26 & -15.5 \\
$1950-1931$ & 19.5 & 90 & 10 & 10 & 8 & -0.8 to -17.5 & -7.3 & -0.38 & 0.29 & -7.3 \\
$1931-1853$ & 77.9 & 100 & 10 & 11 & 9 & -39 to -76 & -55 & -0.71 & 0.15 & -55 \\
\hline
\end{tabular}


Table 1-8. Measured net shoreline movement and end point rate values determined for Heerdt marsh rate-calculation zone HM-7, Corte Madera shoreline.

[Cumulative shoreline movement values determined from average net shoreline movement values starting in 1931. Abbreviations: EPR, end point rate value; $\mathrm{m}$, meter(s); NSM, net shoreline movement value; yr, year(s). Negative values indicate erosion; positive values indicate accretion]

\begin{tabular}{|c|c|c|c|c|c|c|c|c|c|c|}
\hline Epoch & $\begin{array}{c}\text { Epoch } \\
\text { duration } \\
\text { (yr) }\end{array}$ & $\begin{array}{l}\text { Baseline } \\
\text { length }(\mathbf{m})\end{array}$ & $\begin{array}{l}\text { Transect } \\
\text { spacing } \\
\text { (m) }\end{array}$ & $\begin{array}{c}\text { Transects } \\
\text { cast }\end{array}$ & $\begin{array}{c}\text { Transects } \\
\text { used }\end{array}$ & $\begin{array}{c}\text { NSM range } \\
\text { (m) }\end{array}$ & $\begin{array}{c}\text { NSM } \\
\text { average } \\
\text { (m) }\end{array}$ & $\begin{array}{c}\text { EPR } \\
\text { average } \\
\text { (m/yr) }\end{array}$ & $\begin{array}{c}\text { EPR standard } \\
\text { deviation } \\
\text { (m/yr) }\end{array}$ & $\begin{array}{l}\text { Cumulative } \\
\text { shoreline } \\
\text { movement (m) }\end{array}$ \\
\hline 2016-2014 & 1.56 & 39 & 3 & 14 & 11 & -0.16 to -1.75 & -0.70 & -0.45 & 0.28 & -33.7 \\
\hline 2014-2012 & 2.3 & 42 & 3 & 15 & 13 & -0.5 to -2.9 & -1.59 & -0.69 & 0.36 & -33.0 \\
\hline 2012-2009 & 2.53 & 45 & 3 & 16 & 13 & -0.13 to -3.44 & -1.27 & -0.50 & 0.36 & -31.4 \\
\hline 2009-2007 & 2.4 & 45 & 3 & 15 & 11 & -0.1 to -1.2 & -0.46 & -0.19 & 0.14 & -30.1 \\
\hline 2007-2002 & 4.42 & 42 & 3 & 15 & 14 & -0.13 to -2.73 & -1.24 & -0.28 & 0.17 & -29.7 \\
\hline $2002-2000$ & 2.51 & 42 & 3 & 15 & 15 & -1.3 to -3.4 & -1.99 & -0.79 & 0.25 & -28.4 \\
\hline 2000-1992 & 8.17 & 45 & 3 & 16 & 16 & -2.4 to -6.4 & -4.28 & -0.52 & 0.15 & -26.4 \\
\hline 1992-1986 & 6.02 & 48 & 3 & 17 & 16 & -0.4 to -3.9 & -2.18 & -0.36 & 0.18 & -22.2 \\
\hline 1986-1980 & 6.11 & 48 & 3 & 17 & 17 & -0.3 to -3.7 & -2.3 & -0.37 & 0.13 & -20.0 \\
\hline $1980-1975$ & 4.87 & 48 & 3 & 17 & 17 & -0.7 to -1.7 & -1.18 & -0.24 & 0.07 & -17.7 \\
\hline $1975-1970$ & 4.83 & 51 & 3 & 18 & 18 & -1.43 to -3.0 & -2.24 & -0.46 & 0.09 & -16.5 \\
\hline $1970-1965$ & 5.05 & 51 & 3 & 18 & 18 & -0.5 to -2.9 & -1.82 & -0.36 & 0.14 & -14.3 \\
\hline $1965-1950$ & 14.6 & 54 & 3 & 19 & 18 & -3.84 to -5.73 & -4.91 & -0.33 & 0.04 & -12.4 \\
\hline $1950-1931$ & 19.5 & 60 & 6 & 11 & 11 & -5.3 to -10.8 & -7.52 & -0.40 & 0.09 & -7.5 \\
\hline $1931-1853$ & 77.9 & 60 & 10 & 7 & 7 & -47 to -65 & -55 & -0.70 & 0.08 & -55 \\
\hline
\end{tabular}




\section{Appendix 2. End Point Rates for North Muzzi Marsh (North) Rate-Calculation Zone NM-N, Corte Madera Shoreline}

The shoreline at north Muzzi marsh (north) (fig. 2-1), Corte Madera, has experienced overall retreat between the years 1931 to 2016, as indicated by the net shoreline movement and end point rate values (fig. 2-2; table 2-1) measured in this study.

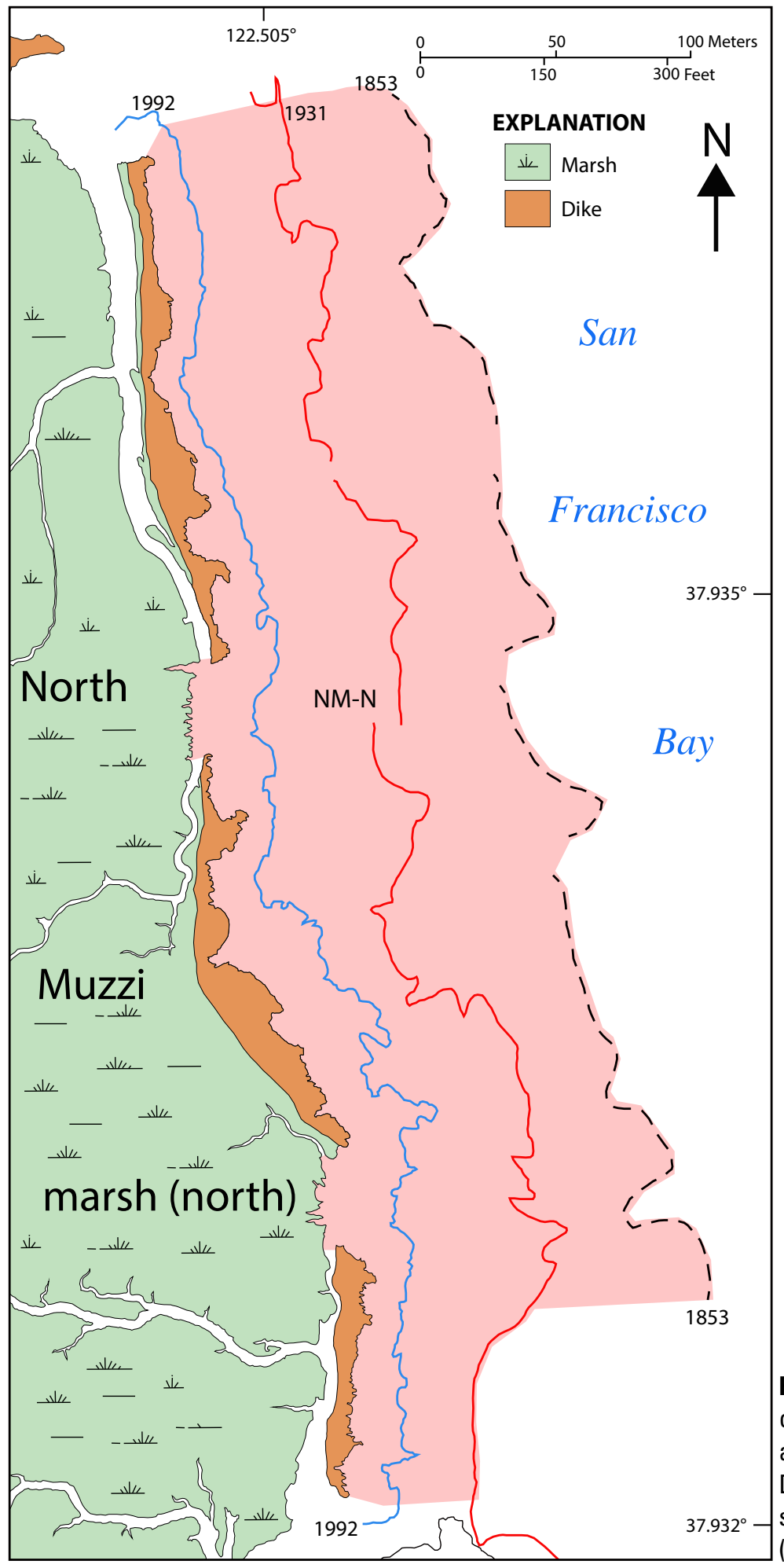

Figure 2-1. Map showing north Muzzi marsh (north) ratecalculation zone NM-N, Corte Madera shoreline, showing area for shoreline-change measurement (pink shading). Dashed black line shows approximate location of 1853 shoreline; colored lines show positions of shoreline in 1931 (red) and 1992 (blue). 


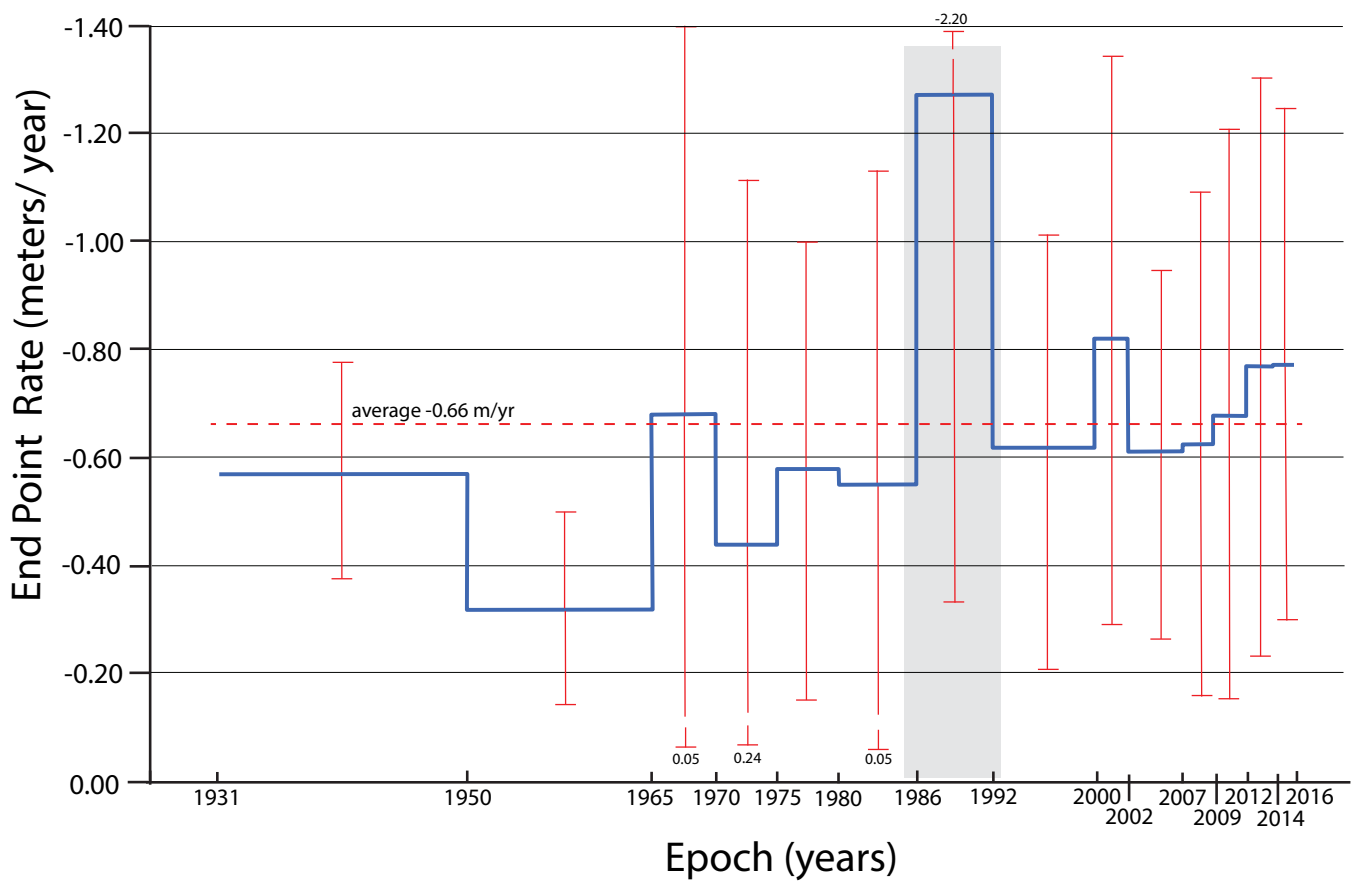

Figure 2-2. Plot showing end point rate values (blue line) for north Muzzi marsh (north) ratecalculation zone NM-N, Corte Madera shoreline. Dashed red line shows averaged retreat value of $-0.66 \mathrm{~m} / \mathrm{yr}$. Gray shading highlights higher rate caused by period of erosion across Muzzi dike borrow canal. Error bars (red lines) are average \pm 1 -sigma variation in rates for each epoch.

Table 2-1. Measured net shoreline movement and end point rate values determined for north Muzzi marsh (north) rate-calculation zone NM-N, Corte Madera shoreline.

[Cumulative shoreline movement values determined from average net shoreline movement values starting in 1931. Abbreviations: EPR, end point rate value; $\mathrm{m}$, meter(s); NSM, net shoreline movement value; yr, year(s). Negative values indicate erosion; positive values indicate accretion]

\begin{tabular}{|c|c|c|c|c|c|c|c|c|c|c|}
\hline Epoch & $\begin{array}{c}\text { Epoch } \\
\text { duration } \\
\text { (yr) }\end{array}$ & $\begin{array}{l}\text { Baseline } \\
\text { length (m) }\end{array}$ & $\begin{array}{c}\text { Transect } \\
\text { spacing }(\mathrm{m})\end{array}$ & $\begin{array}{c}\text { Transects } \\
\text { cast }\end{array}$ & $\begin{array}{c}\text { Transects } \\
\text { used }\end{array}$ & NSM range (m) & $\begin{array}{c}\text { NSM } \\
\text { average } \\
\text { (m) }\end{array}$ & $\begin{array}{c}\text { EPR } \\
\text { average } \\
\text { (m/yr) }\end{array}$ & $\begin{array}{c}\text { EPR standard } \\
\text { deviation } \\
(\mathrm{m} / \mathrm{yr})\end{array}$ & $\begin{array}{l}\text { Cumulative } \\
\text { shoreline } \\
\text { movement (m) }\end{array}$ \\
\hline 2016-2014 & 1.56 & 705 & 15 & 48 & 39 & -0.2 to -3.2 & -1.21 & -0.77 & 0.47 & -51.0 \\
\hline 2014-2012 & 2.3 & 705 & 15 & 48 & 36 & -0.3 to -5.8 & -1.76 & -0.77 & 0.54 & -49.8 \\
\hline 2012-2009 & 2.53 & 675 & 15 & 46 & 44 & -0.1 to -6.4 & -1.72 & -0.68 & 0.53 & -48.0 \\
\hline 2009-2007 & 2.4 & 690 & 15 & 47 & 40 & -0.01 to -4.8 & -1.49 & -0.62 & 0.46 & -46.3 \\
\hline 2007-2002 & 4.42 & 675 & 15 & 46 & 39 & -0.32 to -7.7 & -2.70 & -0.61 & 0.35 & -44.8 \\
\hline $2002-2000$ & 2.51 & 690 & 15 & 47 & 39 & -0.2 to -5.34 & -2.06 & -0.82 & 0.54 & -42.1 \\
\hline 2000-1992 & 8.17 & 675 & 15 & 46 & 38 & -1.1 to -19.1 & -5.05 & -0.62 & 0.40 & -40.1 \\
\hline 1992-1986 & 6.02 & 630 & 15 & 43 & 35 & -0.04 to -18.9 & -7.66 & -1.27 & 0.93 & -35.0 \\
\hline 1986-1980 & 6.11 & 675 & 15 & 46 & 33 & -0.03 to -15.5 & -3.34 & -0.55 & 0.60 & -27.3 \\
\hline 1980-1975 & 4.87 & 690 & 15 & 47 & 37 & -0.07 to -8.7 & -2.82 & -0.58 & 0.42 & -24.0 \\
\hline 1975-1970 & 4.83 & 735 & 15 & 50 & 27 & -0.1 to -17.8 & -2.12 & -0.44 & 0.68 & -21.2 \\
\hline 1970-1965 & 5.05 & 690 & 15 & 47 & 34 & -0.3 to -19.4 & -3.41 & -0.68 & 0.73 & -19.1 \\
\hline 1965-1950 & 14.6 & 630 & 15 & 43 & 33 & -1.2 to -16.1 & -4.74 & -0.32 & 0.19 & -15.6 \\
\hline 1950-1931 & 19.5 & 675 & 15 & 46 & 34 & -4.1 to -23.4 & -10.90 & -0.57 & 0.20 & -10.9 \\
\hline 1931-1853 & 77.9 & 540 & 30 & 19 & 13 & -31 to -66 & -47 & -0.6 & 0.2 & -47 \\
\hline
\end{tabular}




\section{Appendix 3. End Point Rates for North Muzzi Marsh (South) Rate-Calculation Zone NM-S, Corte Madera Shoreline}

The shoreline at north Muzzi marsh (south) (fig. 3-1), Corte Madera, has experienced overall retreat between the years 1931 to 2016, as indicated by the net shoreline movement and end point rate values (fig. 3-2; table 3-1) measured in this study.

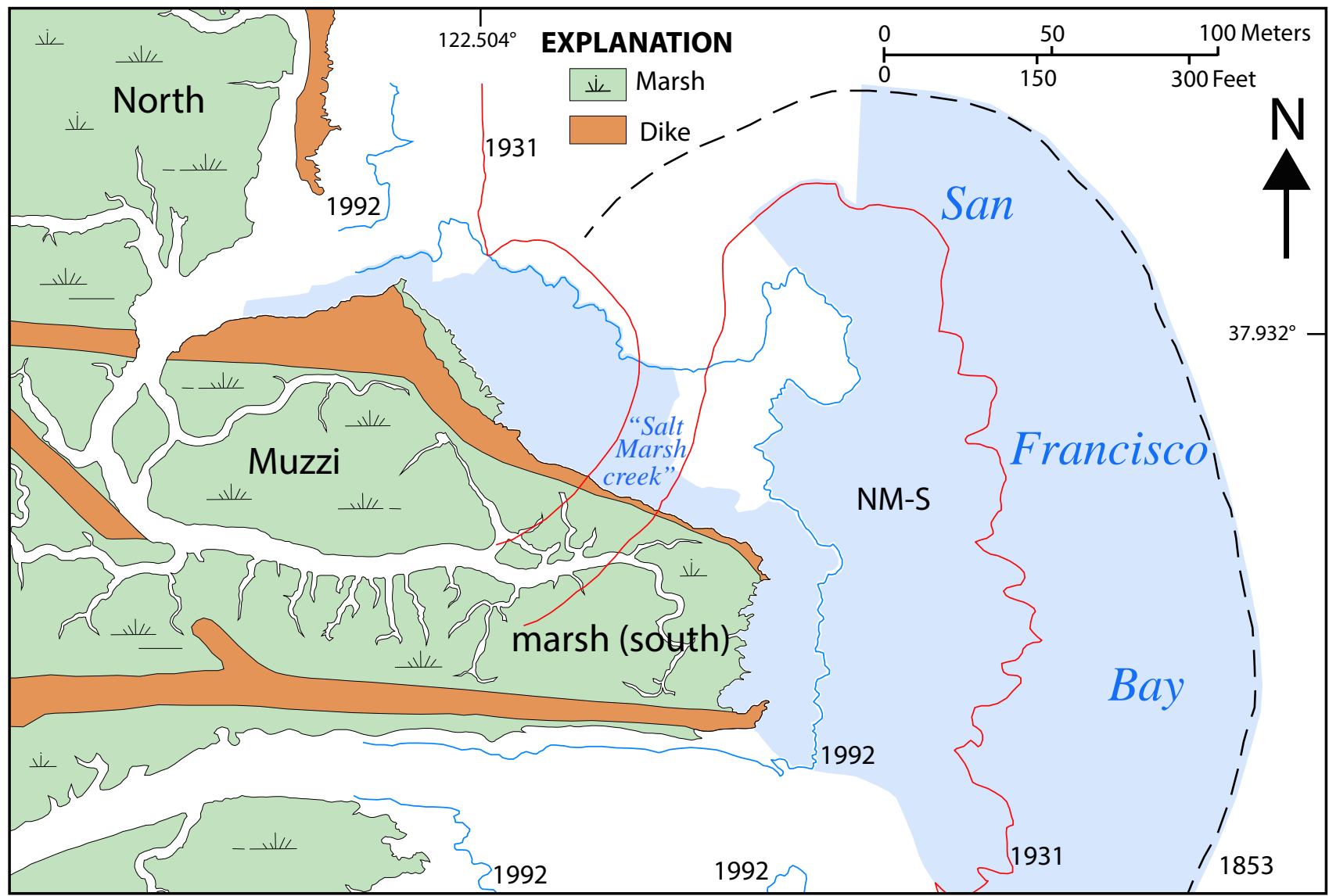

Figure 3-1. Map showing north Muzzi marsh (south) rate-calculation zone NM-S, Corte Madera shoreline, showing area for shoreline-change measurement (blue shading). Dashed black line shows approximate location of 1853 shoreline; colored lines show positions of shoreline in 1931 (red) and 1992 (blue). Mouth of former "Salt Marsh creek" is seen in 1931 shoreline. 


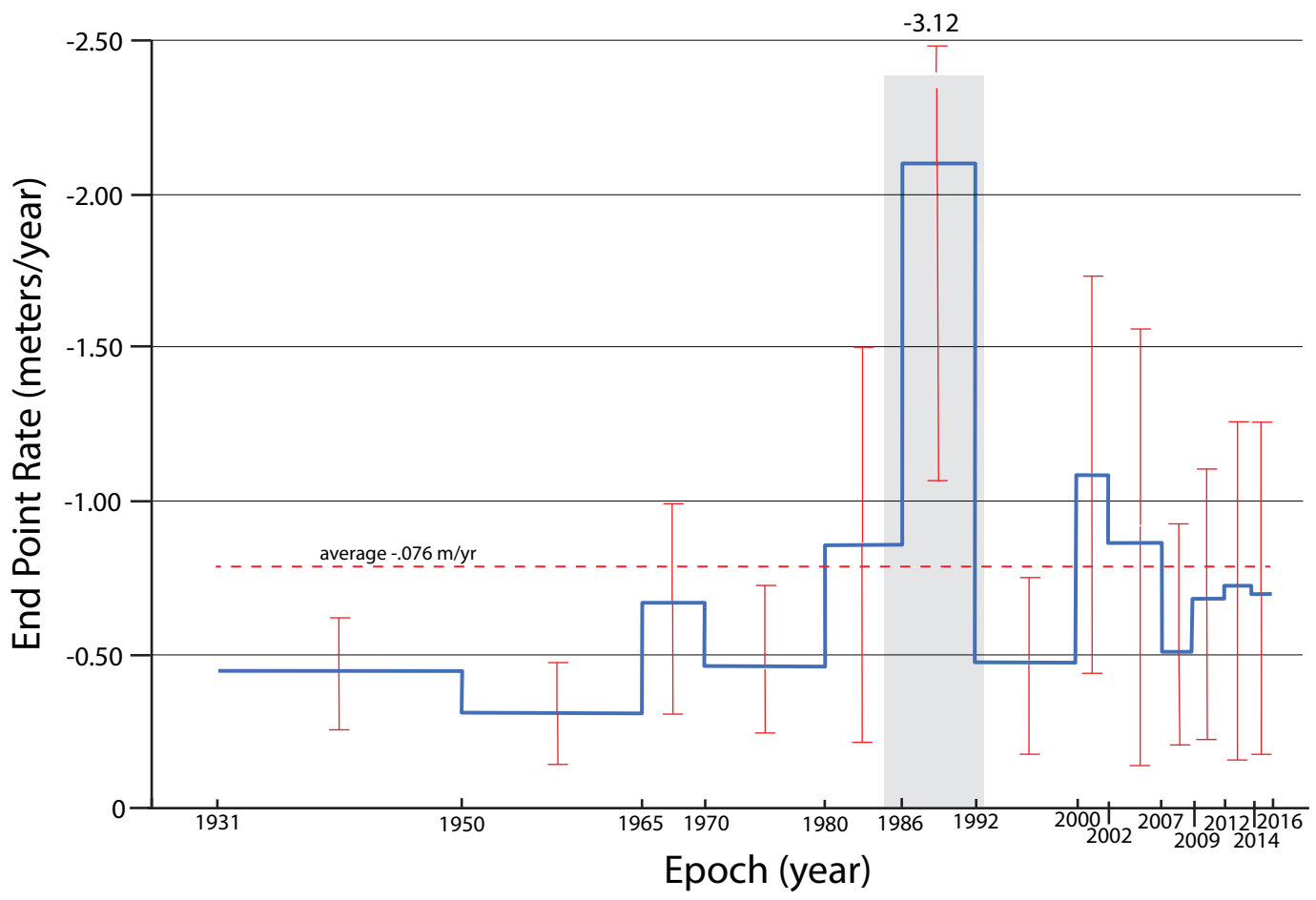

Figure 3-2. Plot showing end point rate values (blue line) for north Muzzi marsh (south) rate-calculation zone NM-S, Corte Madera shoreline. Dashed red line shows averaged retreat value of $-0.76 \mathrm{~m} / \mathrm{yr}$. Gray shading highlights higher rates caused by period of erosion across Muzzi borrow canal. Error bars (red lines) are average \pm 1 -sigma variation in rates for each epoch.

Table 3-1. Measured net shoreline movement and end point rate values determined for north Muzzi marsh (south) rate-calculation zone NM-S, Corte Madera shoreline.

[Cumulative shoreline movement values determined from average net shoreline movement values starting in 1931. Abbreviations: EPR, end point rate value; $\mathrm{m}$, meter(s); NSM, net shoreline movement value; yr, year(s). Negative values indicate erosion; positive values indicate accretion]

\begin{tabular}{|c|c|c|c|c|c|c|c|c|c|c|}
\hline Epoch & $\begin{array}{c}\text { Epoch } \\
\text { duration } \\
\text { (yr) }\end{array}$ & $\begin{array}{l}\text { Baseline } \\
\text { length }(\mathrm{m})\end{array}$ & $\begin{array}{c}\text { Transect } \\
\text { spacing (m) }\end{array}$ & $\begin{array}{c}\text { Transects } \\
\text { cast }\end{array}$ & $\begin{array}{c}\text { Transects } \\
\text { used }\end{array}$ & NSM range $(\mathrm{m})$ & $\begin{array}{c}\text { NSM } \\
\text { average } \\
(\mathrm{m})\end{array}$ & $\begin{array}{c}\text { EPR } \\
\text { average } \\
\text { (m/yr) }\end{array}$ & $\begin{array}{c}\text { EPR standard } \\
\text { deviation } \\
\text { (m/yr) }\end{array}$ & $\begin{array}{c}\text { Cumulative } \\
\text { shoreline } \\
\text { movement (m) }\end{array}$ \\
\hline 2016-2014 & 1.56 & 276 & 4 & 70 & 60 & -0.2 to -4.4 & -1.10 & -0.70 & 0.55 & -55.0 \\
\hline 2014-2012 & 2.3 & 280 & 4 & 71 & 56 & -0.3 to -6.7 & -1.66 & -0.72 & 0.53 & -53.9 \\
\hline 2012-2009 & 2.53 & 296 & 4 & 75 & 62 & -0.2 to -4.8 & -1.72 & -0.68 & 0.44 & -52.2 \\
\hline 2009-2007 & 2.4 & 288 & 4 & 73 & 58 & -0.1 to -3.4 & -1.23 & -0.51 & 0.31 & -50.5 \\
\hline 2007-2002 & 4.42 & 276 & 6 & 47 & 37 & -0.04 to -15.3 & -3.81 & -0.86 & 0.72 & -49.2 \\
\hline $2002-2000$ & 2.51 & 288 & 6 & 49 & 37 & -0.43 to -7 & -2.72 & -1.08 & 0.65 & -45.4 \\
\hline 2000-1992 & 8.17 & 355 & 5 & 72 & 32 & -0.04 to -9.5 & -3.87 & -0.48 & 0.30 & -42.7 \\
\hline 1992-1986 & 6.02 & 210 & 10 & 22 & 15 & -3.3 to -23.4 & -12.70 & -2.10 & 1.02 & -38.8 \\
\hline 1986-1980 & 6.11 & 224 & 8 & 29 & 22 & -0.24 to -15 & -5.20 & -0.85 & 0.65 & -26.1 \\
\hline $1980-1970$ & 9.7 & 248 & 8 & 32 & 24 & -2.54 to -12.9 & -4.48 & -0.46 & 0.25 & -20.9 \\
\hline 1970-1965 & 5.05 & 232 & 8 & 30 & 28 & -0.26 to -6.3 & -3.36 & -0.67 & 0.31 & -16.5 \\
\hline 1965-1950 & 14.6 & 248 & 8 & 32 & 29 & -0.9 to -14.9 & -4.56 & -0.31 & 0.17 & -13.1 \\
\hline $1950-1931$ & 19.5 & 288 & 8 & 37 & 27 & -4.2 to 15.6 & -8.54 & -0.45 & 0.16 & -8.5 \\
\hline $1931-1853$ & 77.9 & 250 & 25 & 11 & 10 & -34 to -81 & -60 & -0.77 & 0.18 & -60 \\
\hline
\end{tabular}




\section{Appendix 4. End Point Rates for Outer Muzzi Marsh Rate-Calculation Zone OM, Corte Madera Shoreline}

The shoreline at outer Muzzi marsh (fig. 4-1), Corte Madera, has experienced overall retreat between the years 1931 to 2016, as indicated by the net shoreline movement and end point rate values (fig. 4-2; table 4-1) measured in this study.

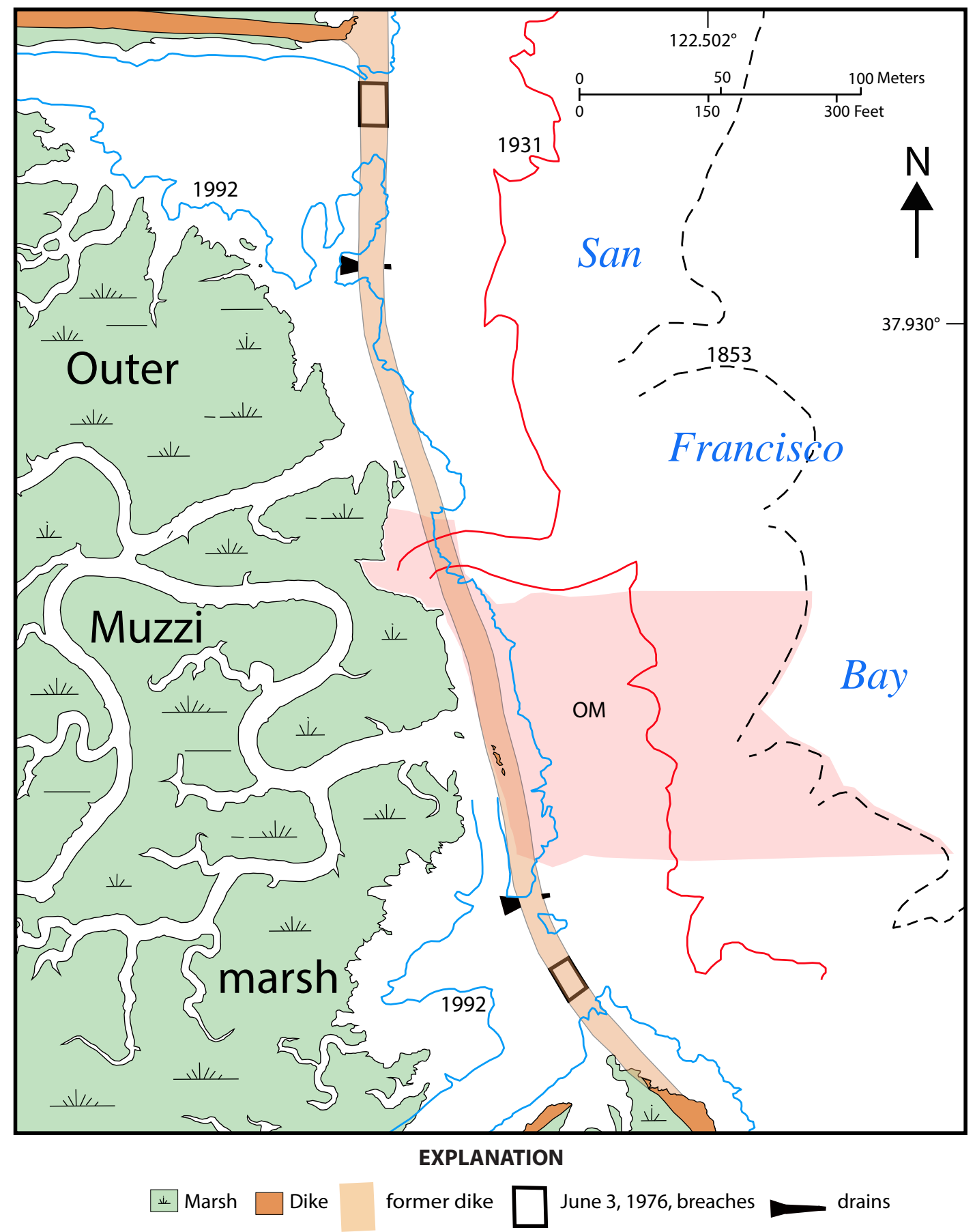

Figure 4-1. Map showing outer Muzzi marsh rate-calculation zone OM, Corte Madera shoreline, showing area for shoreline-change measurement (pink shading). Dashed black line shows approximate location of 1853 shoreline; colored lines show positions of shoreline in 1931 (red) and 1992 (blue). 


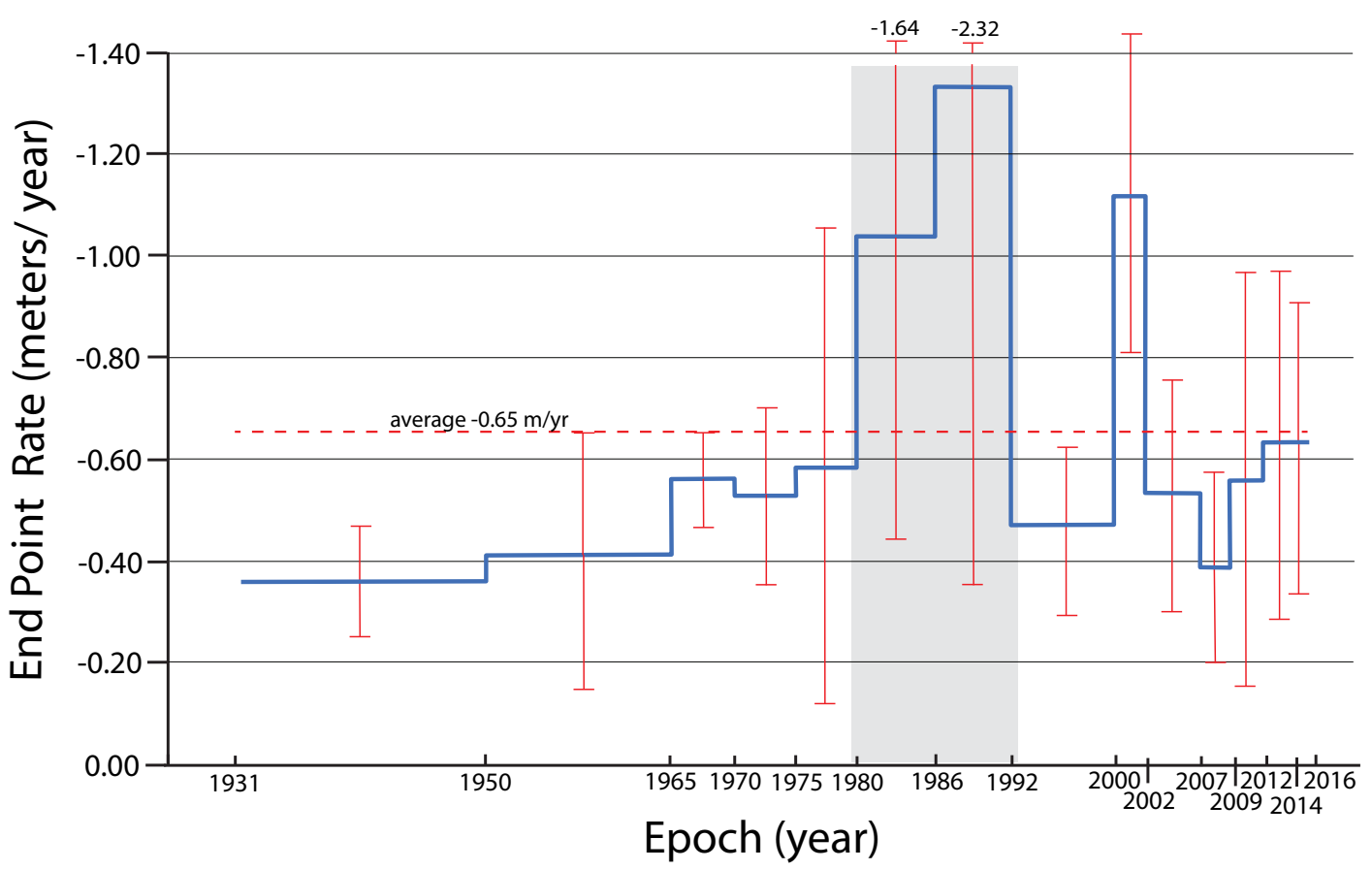

Figure 4-2. Plot showing end point rate values (blue line) for outer Muzzi marsh ratecalculation zone OM, Corte Madera shoreline. Dashed red line shows averaged retreat value of $-0.65 \mathrm{~m} / \mathrm{yr}$. Gray shading highlights higher rates caused by period of erosion across Muzzi borrow canal. Error bars (red lines) are average \pm 1 -sigma variation in rates for each epoch.

Table 4-1. Measured net shoreline movement and end point rate values determined for outer Muzzi marsh rate-calculation zone OM, Corte Madera shoreline.

[Cumulative shoreline movement values determined from average net shoreline movement values starting in 1931. Abbreviations: EPR, end point rate value; $\mathrm{m}$, meter(s); NSM, net shoreline movement value; yr, year(s). Negative values indicate erosion; positive values indicate accretion]

\begin{tabular}{|c|c|c|c|c|c|c|c|c|c|c|}
\hline Epoch & $\begin{array}{c}\text { Epoch } \\
\text { duration } \\
\text { (yr) }\end{array}$ & $\begin{array}{l}\text { Baseline } \\
\text { length }(\mathrm{m})\end{array}$ & $\begin{array}{c}\text { Transect } \\
\text { spacing }(\mathbf{m})\end{array}$ & $\begin{array}{c}\text { Transects } \\
\text { cast }\end{array}$ & $\begin{array}{c}\text { Transects } \\
\text { used }\end{array}$ & NSM range (m) & $\begin{array}{c}\text { NSM } \\
\text { average } \\
\text { (m) }\end{array}$ & $\begin{array}{c}\text { EPR } \\
\text { average } \\
\text { (m/yr) }\end{array}$ & $\begin{array}{c}\text { EPR standard } \\
\text { deviation } \\
\text { (m/yr) }\end{array}$ & $\begin{array}{c}\text { Cumulative } \\
\text { shoreline } \\
\text { movement (m) }\end{array}$ \\
\hline 2016-2014 & 1.56 & 156 & 4 & 40 & 18 & -0.34 to -1.8 & -0.99 & -0.63 & 0.27 & -49.3 \\
\hline 2014-2012 & 2.3 & 156 & 4 & 40 & 21 & -0.5 to -3.6 & -1.45 & -0.63 & 0.34 & -48.3 \\
\hline 2012-2009 & 2.53 & 180 & 4 & 46 & 29 & -0.1 to -4 & -1.4 & -0.56 & 0.41 & -46.9 \\
\hline 2009-2007 & 2.4 & 172 & 4 & 44 & 29 & -0.1 to -1.8 & -0.93 & -0.39 & 0.18 & -45.5 \\
\hline 2007-2002 & 4.42 & 184 & 4 & 47 & 31 & -0.6 to -5 & -2.36 & -0.53 & 0.22 & -44.6 \\
\hline $2002-2000$ & 2.51 & 156 & 4 & 40 & 32 & -1.3 to -4.7 & -2.81 & -1.12 & 0.31 & -42.2 \\
\hline 2000-1992 & 8.17 & 160 & 4 & 41 & 31 & -1.8 to -7.7 & -3.83 & -0.47 & 0.16 & -39.4 \\
\hline 1992-1986 & 6.02 & 144 & 6 & 25 & 21 & -0.9 to -22 & -8.05 & -1.34 & 0.98 & -35.6 \\
\hline 1986-1980 & 6.11 & 132 & 6 & 23 & 20 & -1.9 to -12 & -6.34 & -1.04 & 0.6 & -27.5 \\
\hline 1980-1975 & 4.87 & 150 & 5 & 31 & 18 & -0.3 to -7 & -2.83 & -0.58 & 0.47 & -21.2 \\
\hline 1975-1970 & 4.83 & 105 & 5 & 22 & 20 & -0.2 to -3.4 & -2.56 & -0.53 & 0.17 & -18.3 \\
\hline 1970-1965 & 5.05 & 110 & 5 & 23 & 21 & -1.9 to -3.5 & -2.82 & -0.56 & 0.09 & -15.8 \\
\hline 1965-1950 & 14.6 & 105 & 5 & 22 & 20 & -2 to -14 & -6.14 & -0.41 & 0.24 & -13.0 \\
\hline 1950-1931 & 19.5 & 115 & 5 & 24 & 16 & -3.3 to -11.5 & -6.82 & -0.36 & 0.11 & -6.8 \\
\hline $1931-1853$ & 77.9 & 100 & 20 & 6 & 6 & -36 to -97 & -60 & -0.80 & 0.3 & -60 \\
\hline
\end{tabular}




\section{Appendix 5. End Point Rates for Marta's Marsh Rate-Calculation Zone MM, Corte Madera Shoreline}

The shoreline at Marta's marsh (fig. 5-1), Corte Madera, has experienced overall retreat between the years 1931 to 2016, as indicated by the net shoreline movement and end point rate values (fig. 5-2; table 5-1) measured in this study.

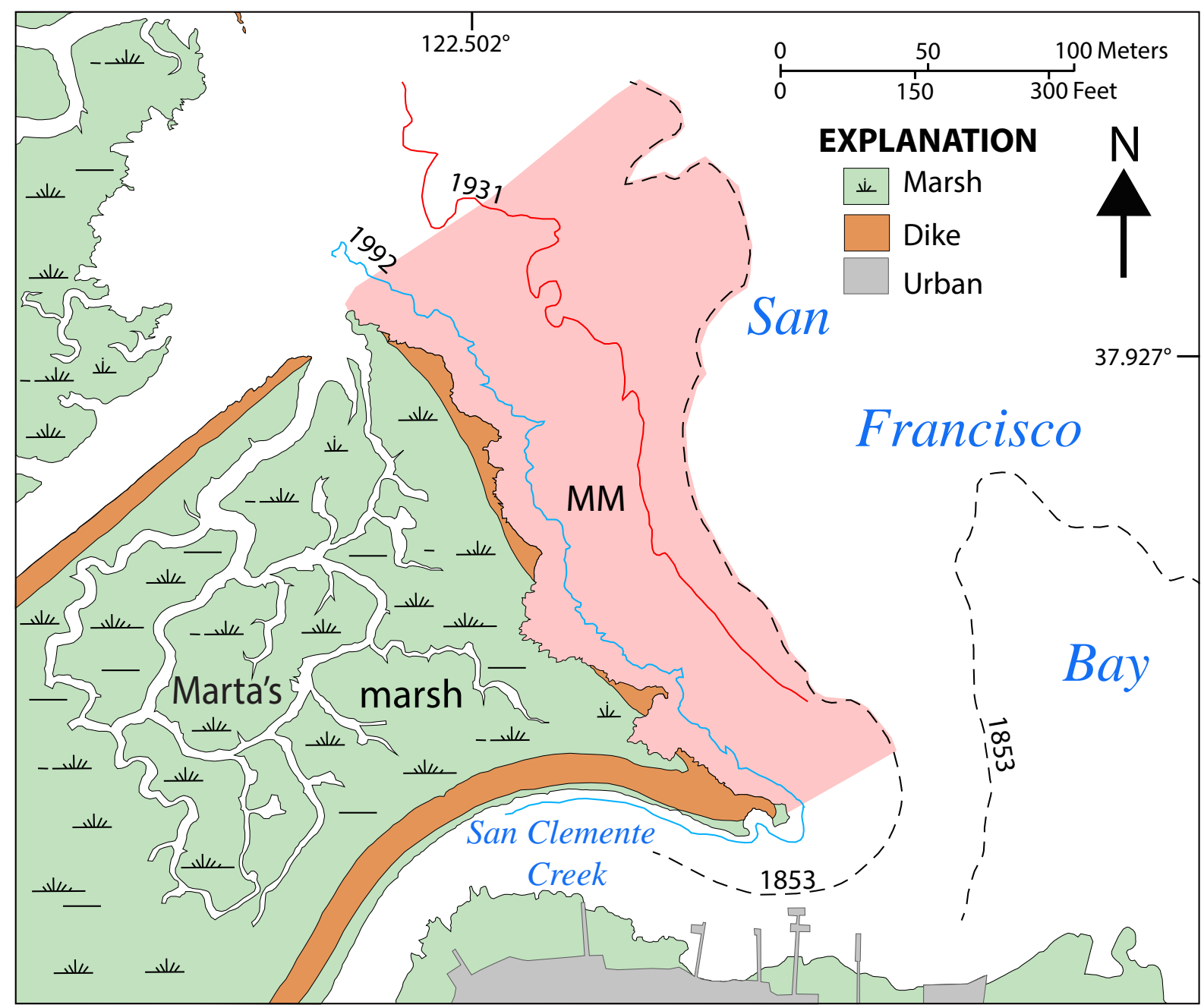

Figure 5-1. Map showing Marta's marsh rate-calculation zone MM, Corte Madera shoreline, showing area for shoreline change measurement (pink shading). Dashed black line shows approximate location of 1853 shoreline; colored lines show positions of shoreline in 1931 (red) and 1992 (blue). 


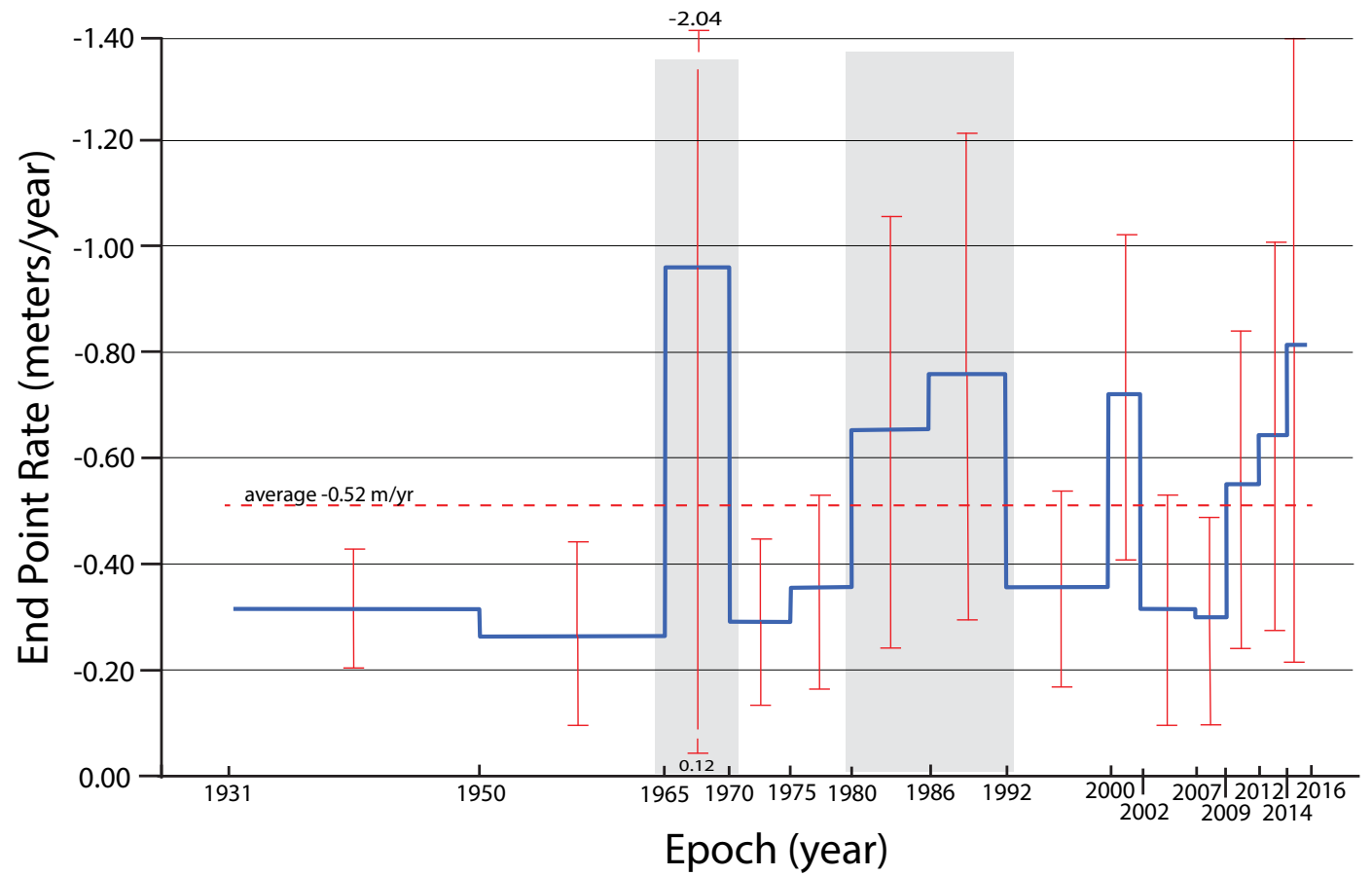

Figure 5-2. Plot showing end point rate values (blue line) for Marta's marsh rate-calculation zone MM, Corte Madera shoreline. Dashed red line shows averaged retreat value of $-0.52 \mathrm{~m} / \mathrm{yr}$. Gray shading highlights higher rates caused by periods of erosion across Muzzi borrow canal. Error bars (red lines) are average \pm 1 -sigma variation in rates for each epoch.

Table 5-1. Measured net shoreline movement and end point rate values determined for Marta's marsh rate-calculation zone MM, Corte Madera shoreline.

[Cumulative shoreline movement values determined from average net shoreline movement values starting in 1931. Abbreviations: EPR, end point rate value; $m$, meter(s); NSM, net shoreline movement value; yr, year(s). Negative values indicate erosion; positive values indicate accretion]

\begin{tabular}{|c|c|c|c|c|c|c|c|c|c|c|}
\hline Epoch & $\begin{array}{c}\text { Epoch } \\
\text { duration } \\
\text { (yr) }\end{array}$ & $\begin{array}{l}\text { Baseline } \\
\text { length }(\mathrm{m})\end{array}$ & $\begin{array}{c}\text { Transect } \\
\text { spacing } \\
\text { (m) }\end{array}$ & $\begin{array}{l}\text { Transects } \\
\text { cast }\end{array}$ & $\begin{array}{l}\text { Transects } \\
\text { used }\end{array}$ & $\begin{array}{l}\text { NSM range } \\
(\mathrm{m})\end{array}$ & $\begin{array}{l}\text { NSM } \\
\text { average } \\
\text { (m) }\end{array}$ & $\begin{array}{c}\text { EPR } \\
\text { average } \\
(\mathrm{m} / \mathrm{yr})\end{array}$ & $\begin{array}{l}\text { EPR standard } \\
\text { deviation } \\
(\mathrm{m} / \mathrm{yr})\end{array}$ & $\begin{array}{l}\text { Cumulative } \\
\text { shoreline } \\
\text { movement (m) }\end{array}$ \\
\hline 2016-2014 & 1.56 & 324 & 9 & 37 & 35 & -0.1 to -4.2 & -1.27 & -0.81 & 0.59 & -37.3 \\
\hline 2014-2012 & 2.3 & 324 & 9 & 37 & 33 & -0.12 to -3.9 & -1.47 & -0.64 & 0.37 & -36.0 \\
\hline 2012-2009 & 2.53 & 342 & 9 & 39 & 35 & -0.43 to -3.54 & -1.39 & -0.55 & 0.30 & -34.6 \\
\hline 2009-2007 & 2.4 & 333 & 9 & 38 & 33 & -0.01 to -1.9 & -0.71 & -0.30 & 0.20 & -33.2 \\
\hline $2007-2002$ & 4.42 & 324 & 9 & 37 & 34 & -0.01 to -4.3 & -1.39 & -0.31 & 0.22 & -32.5 \\
\hline $2002-2000$ & 2.51 & 306 & 9 & 35 & 32 & -0.53 to -4 & -1.81 & -0.72 & 0.31 & -31.1 \\
\hline 2000-1992 & 8.17 & 306 & 9 & 35 & 32 & -0.6 to -6.9 & -2.90 & -0.35 & 0.19 & -29.3 \\
\hline 1992-1986 & 6.02 & 288 & 9 & 33 & 30 & -0.3 to -9.6 & -4.56 & -0.76 & 0.47 & -26.4 \\
\hline 1986-1980 & 6.11 & 351 & 9 & 40 & 36 & -0.6 to -10.24 & -3.97 & -0.65 & 0.41 & -21.8 \\
\hline 1980-1975 & 4.87 & 315 & 9 & 36 & 28 & -0.56 to -3.56 & -1.73 & -0.35 & 0.18 & -17.8 \\
\hline 1975-1970 & 4.83 & 342 & 9 & 39 & 30 & -0.16 to -2.7 & -1.40 & -0.29 & 0.15 & -16.1 \\
\hline 1970-1965 & 5.05 & 360 & 9 & 41 & 30 & -0.2 to -17.2 & -4.82 & -0.96 & 1.08 & -14.7 \\
\hline $1965-1950$ & 14.6 & 297 & 9 & 34 & 30 & -1.6 to -16.3 & -3.92 & -0.26 & 0.17 & -9.9 \\
\hline $1950-1931$ & 19.5 & 252 & 9 & 29 & 24 & -1.9 to -13.7 & -5.97 & -0.31 & 0.11 & -6.0 \\
\hline 1931-1853 & 77.9 & 225 & 15 & 16 & 16 & -4 to -81 & -29 & -0.4 & 0.32 & -29 \\
\hline
\end{tabular}




\section{Appendix 6. End Point Rates for Triangle Marsh Rate-Calculation Zone TM, Corte Madera Shoreline}

The shoreline at Triangle marsh (fig. 6-1), Corte Madera, has experienced overall retreat between the years 1931 to 2016 , as indicated by the net shoreline movement and end point rate values (fig. 6-2; table 6-1) measured in this study.

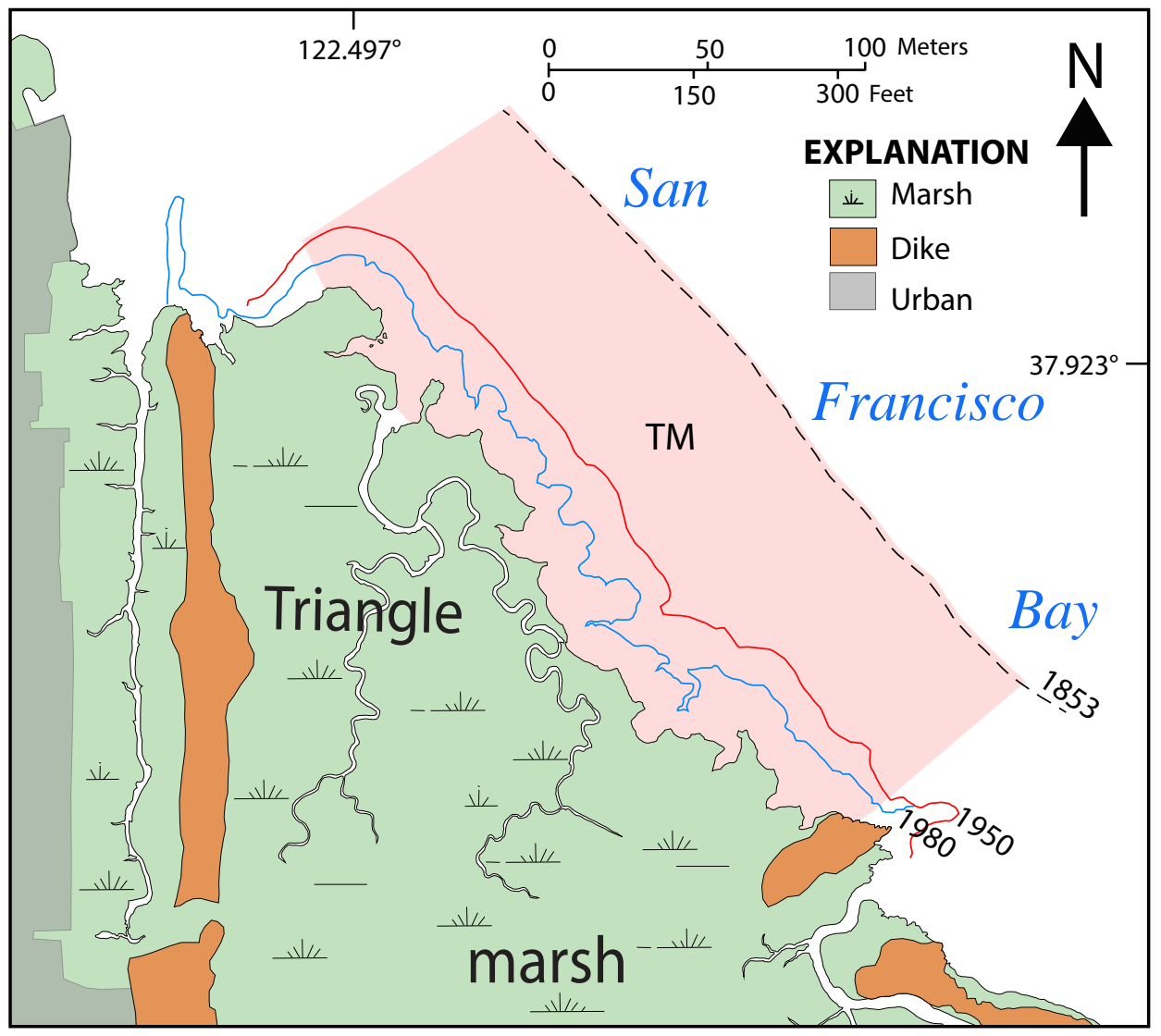

Figure 6-1. Map showing Triangle marsh rate-calculation zone TM, Corte Madera shoreline, showing area for shoreline-change measurement (pink shading). Dashed black line shows approximate location of 1853 shoreline; colored lines show positions of shoreline in 1950 (red) and 1980 (blue). 


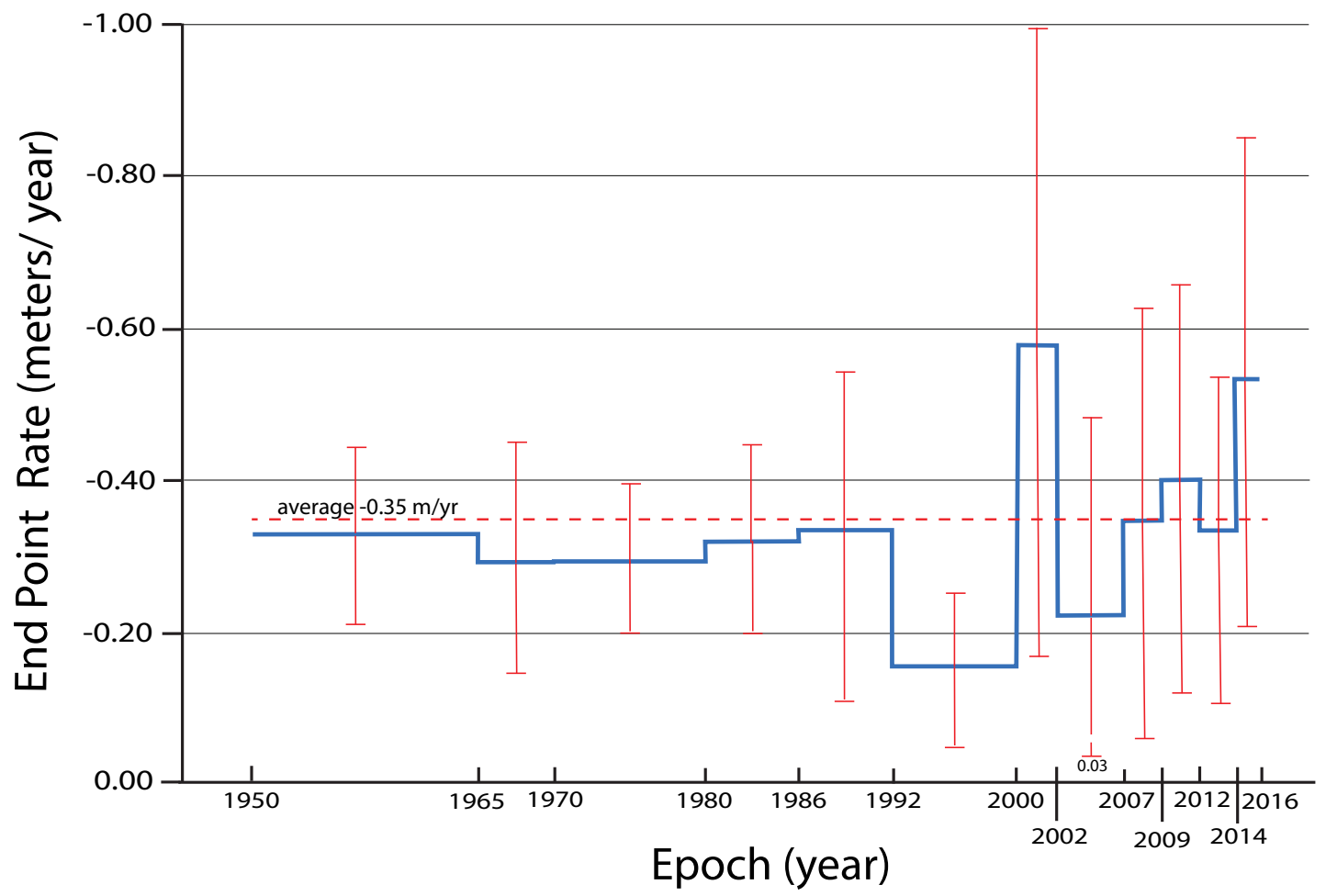

Figure 6-2. Plot showing end point rate values (blue line) for Triangle marsh rate-calculation zone TM, Corte Madera shoreline. Dashed red line shows averaged retreat value of $-0.35 \mathrm{~m} / \mathrm{yr}$. Error bars (red lines) are average \pm 1 -sigma variation in rates for each epoch.

Table 6-1. Measured net shoreline movement and end point rate values determined for Triangle marsh rate-calculation zone TM, Corte Madera shoreline.

[Cumulative shoreline movement values determined from average net shoreline movement values starting in 1950. Abbreviations: EPR, end point rate value; $\mathrm{m}$, meter(s); NSM, net shoreline movement value; yr, year(s). Negative values indicate erosion; positive values indicate accretion]

\begin{tabular}{|c|c|c|c|c|c|c|c|c|c|c|}
\hline Epoch & $\begin{array}{c}\text { Epoch } \\
\text { duration } \\
\text { (yr) }\end{array}$ & $\begin{array}{l}\text { Baseline } \\
\text { length }(\mathrm{m})\end{array}$ & $\begin{array}{c}\text { Transect } \\
\text { spacing }(\mathbf{m})\end{array}$ & $\begin{array}{c}\text { Transects } \\
\text { cast }\end{array}$ & $\begin{array}{c}\text { Transects } \\
\text { used }\end{array}$ & NSM range (m) & $\begin{array}{c}\text { NSM } \\
\text { average } \\
\text { (m) }\end{array}$ & $\begin{array}{c}\text { EPR } \\
\text { average } \\
\text { (m/yr) }\end{array}$ & $\begin{array}{c}\text { EPR standard } \\
\text { deviation } \\
\text { (m/yr) }\end{array}$ & $\begin{array}{c}\text { Cumulative } \\
\text { shoreline } \\
\text { movement (m) }\end{array}$ \\
\hline 2016-2014 & 1.56 & 456 & 12 & 39 & 34 & -0.03 to -2.5 & -0.84 & -0.53 & 0.32 & -20.4 \\
\hline 2014-2012 & 2.3 & 456 & 12 & 39 & 24 & -0.1 to -1.7 & -0.76 & -0.33 & 0.21 & -19.6 \\
\hline 2012-2009 & 2.53 & 432 & 12 & 37 & 35 & -0.13 to -3.13 & -1.02 & -0.40 & 0.27 & -18.8 \\
\hline 2009-2007 & 2.4 & 444 & 12 & 38 & 26 & -0.01 to -2.33 & -0.84 & -0.35 & 0.28 & -17.8 \\
\hline 2007-2002 & 4.42 & 444 & 12 & 38 & 30 & -0.03 to -5.24 & -0.98 & -0.22 & 0.25 & -17.0 \\
\hline $2002-2000$ & 2.51 & 444 & 12 & 38 & 32 & -0.23 to -5.4 & -1.45 & -0.58 & 0.41 & -16.0 \\
\hline $2000-1992$ & 8.17 & 420 & 12 & 36 & 25 & -0.3 to -3.9 & -1.28 & -0.16 & 0.10 & -14.5 \\
\hline 1992-1986 & 6.02 & 372 & 12 & 32 & 28 & -0.06 to -4.53 & -2.02 & -0.33 & 0.21 & -13.2 \\
\hline 1986-1980 & 6.11 & 384 & 12 & 33 & 27 & -0.48 to -3.56 & -1.96 & -0.32 & 0.12 & -11.2 \\
\hline 1980-1970 & 9.7 & 372 & 12 & 32 & 25 & -0.6 to -5.1 & -2.86 & -0.29 & 0.10 & -9.3 \\
\hline $1970-1965$ & 5.05 & 348 & 12 & 30 & 25 & -0.2 to -2.8 & -1.47 & -0.29 & 0.14 & -6.4 \\
\hline $1965-1950$ & 14.6 & 324 & 12 & 28 & 22 & -0.43 to -7.94 & -4.93 & -0.33 & 0.11 & -4.9 \\
\hline $1950-1853$ & 97.4 & 240 & 12 & 21 & 21 & -50 to -66 & -57.0 & -0.6 & 0.1 & -57 \\
\hline
\end{tabular}


Moffet Field Publishing Service Center, California Manuscript approved for publication June 17, 2020 Edited by Taryn A. Lindquist Layout and design by Kimber Petersen 


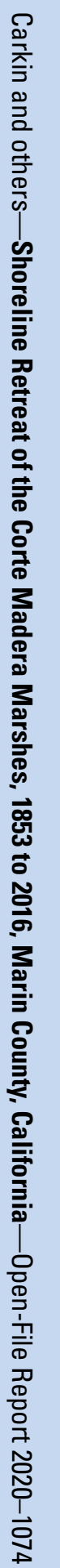

